\title{
Cultura e Emancipação através de T.W. Adorno: Formação e Arte
}

(VERSÃO CORRIGIDA)

\begin{abstract}
Dissertação apresentada ao Instituto de Psicologia da Universidade de São Paulo, como parte dos requisitos para obtenção do grau de Mestre em Psicologia
\end{abstract}

Área de Concentração

Psicologia Escolar e do

Desenvolvimento Humano

Orientadora

Profa. Dra. Iray Carone 
AUTORIZO A REPRODUÇÃO E DIVULGAÇÃO

TOTAL OU PARCIAL DESTE TRABALHO,

POR QUALQUER MEIO CONVENCIONAL

OU ELETRÔNICO, PARA FINS DE ESTUDO E

PESQUISA, DESDE QUE CITADA A FONTE.

Catalogação na publicação

Biblioteca Dante Moreira Leite

Instituto de Psicologia da Universidade de São Paulo

Nascimento, Rafael Baioni do.

Cultura e emancipação através de T. W. Adorno: formação e arte / Rafael Baioni do Nascimento; orientadora Iray Carone. -- São Paulo, 2010.

$171 \mathrm{f}$.

Dissertação (Mestrado - Programa de Pós-Graduação em Psicologia. Área de Concentração: Psicologia Escolar e do Desenvolvimento Humano) - Instituto de Psicologia da Universidade de São Paulo.

1. Teoria crítica 2. Cultura 3. Emancipação 4. Formação do indivíduo 5. Arte-educação 6. Arte e sociedade I. Título. 


\title{
Cultura e Emancipação através de T.W. Adorno: Formação e Arte
}

\author{
RAFAEL BAIONI DO NASCIMENTO \\ Orientadora \\ PROFA. DRA. IRAY CARONE
}

Banca Examinadora

(nome e assinatura)

(nome e assinatura)

(nome e assinatura)

Dissertação defendida e aprovada em: 
Aos meus pais, Roosvelt e Edília, pela confiança, pelo apoio e por tudo que me ensinaram: do amor pela verdade ao benefício da dúvida. 


\section{Agradecimentos}

Obrigado Iray, pelo acolhimento, pela orientação cuidadosa, pelos comentários valiosos, pelos textos que só você poderia ter encontrado e pela autonomia dada quando autonomia era preciso. Sua companhia é a de uma amiga rara, estimada no mais alto grau.

Agradeço também ao Prof. Dr. José Leon Crochík, pela introdução à Teoria Crítica ainda na graduação, pelos anos seguintes de ensino, por tudo que aprendi com o rigor da sua pesquisa e com o debate intenso e rico.

Às Profas. Dras. Ana Maria Loffredo, Maria Helena Souza Patto e Maria Luisa Sandoval Schmidt pelo exemplo que me deram, durante a graduação, de coerência entre o ensino e aquilo que é ensinado, entre a forma e o conteúdo, do qual esta dissertação é um desdobramento. E à última, um agradecimento a mais, ainda, pelas valiosas contribuições no exame de qualificação, assim como ao Prof. Dr. Celso Favaretto, a quem devo boa parte dos novos rumos tomados na dissertação final.

Aos meus irmãos Rodrigo, Bruna e Keren pela cumplicidade em tudo e pelo apoio incondicional, mesmo quando não o merecia.

Aos meus amigos, Maíra, Fernando, Gustavo, Lessi, Ariel e Caru, que conviveram comigo esses anos de mestrado, e Jô e Ana Aranha Dantas pelas conversas maravilhosas sobre formação e arte durante esses mais de dez anos.

Um agradecimento especial também ao Luiz Fukushiro, pela companhia indispensável, pela leitura atenta, pela revisão, pelo projeto gráfico e diagramação deste trabalho.

Obrigado também à CAPES, pela bolsa que possibilitou a realização deste. 
Quase todos os homens sonham, nos secretos do seu ser, um grande imperialismo próprio, a sujeição de todos os homens, a entrega de todas as mulheres, a adoração dos povos, e, nos mais nobres, de todas as eras... Poucos como eu habituados ao sonho, são por isso lúcidos bastante para rir da possibilidade estética de se sonhar assim.

— Livro do Desassossego 


\section{Resumo}

nascimento, Rafael Baioni do. Cultura e emancipação através de T.W. Adorno: formação e arte. 2010. 171f. Dissertação (mestrado) - Instituto de Psicologia, Universidade de São Paulo, São Paulo, 2010.

O presente trabalho investiga algumas das articulações entre indivíduo e obra de arte através de quatro conceitos fundamentais encontrados na obra de T.w. Adorno: cultura, emancipação, formação e arte, abordados de forma constelacional. O método utilizado foi a análise de textos do próprio autor, de alguns escritos em conjunto com Horkheimer, de alguns de outros autores da Teoria Crítica (Benjamim e Marcuse) e de outros de autores tradicionais do pensamento alemão (Kant, Schiller e Goethe); assim como textos de seus comentadores. A hipótese que nos guia é a de que, apesar da tendência dominante de desaparecimento do sujeito e da arte autônomos, apontados por Adorno, sua própria teoria, ao fazer tal diagnóstico criticamente, já é parte da cura possível; que a crítica da formação e a crítica da arte, intrinsecamente conectadas, são uma práxis transformadora no caminho de uma emancipação de ambos. E concluímos que o conteúdo de verdade e a dimensão histórica - também intrínsecos - que emergem necessariamente de toda crítica à formação, quanto de toda crítica às obras de arte, apontam para o sofrimento vivido, e o reconhecimento desse sofrimento, na educação de arte, promove, dentro do possível, nas condições atuais, a verdadeira experiência com as obras de arte e com isso, ao mesmo tempo, pode promover uma formação emancipatória.

Palavras-chave: Teoria Crítica, Cultura, Emancipação, Formação, Arte e Educação, Arte e Sociedade. 


\begin{abstract}
nascimento, Rafael Baioni do. Culture and emancipation through T.W. Adorno: formation and art. 2010. 171f. Dissertation (Master's degree) - Institute of Psychology, University of São Paulo, São Paulo, 2010.
\end{abstract}

This study investigates some of the intersections between individual and artwork through four key concepts found in the work of T.w. Adorno: culture, emancipation, formation and art, in a constellational approach. The employed method was the analysis of the author's texts, some written along with Horkheimer, some by other Critical Theory authors (Benjamin and Marcuse) and some by authors of the German tradition (Kant, Schiller and Goethe) so as texts of their critics. The hypothesis that guides us is that despite the dominant tendency of the disappearance of the subject and the autonomous art, pointed out by Adorno, his own theory, through making such a diagnosis critically, is part of a possible healing; that the critique of formation and art criticism, intrinsically linked, are a transformative praxis in the way of their emancipation. We conclude that the truth content and historical dimension - also intrinsic that emerge necessarily from all critic of formation, the same way as any criticism of artworks, pointed out to the suffering, and the recognition of this suffering in art education promotes, within possibility, under current social conditions, the true experience towards the artworks, and that might promote an emancipatory formation.

Keywords: Critical Theory, Culture, Emancipation, Formation, Art and Education, Art and Society. 


\section{Sumário}

Introdução 10

I O CONCEITO DE CULTURA

1 Cultura e Civilização \& Cultura e Sociedade 16

2 Cultura e Natureza \& Cultura e Barbárie 24

3 O Conceito de Indústria Cultural 34

II O CONCEITO DE EMANCIPAÇÃO

1 Emancipação e Aufklärung 39

2 O Modelo da Mônada 45

3 Teoria e Práxis 48

III O CONCEITO DE FORMAÇÃO

1 Formação enquanto Bildung 55

2 Bildung e o Wilhelm Meister de Goethe 58

3 Formação e a Educação Estética de Schiller 65

4 Adorno e a Semiformação 77

5 Formação e Educação 84

IV O CONCEITO DE ARTE

Nota sobre a Teoria Estética 96

1 Arte, Sociedade e Sujeito 97

2 Arte Moderna Radical 110

3 O Conceito de Mímesis 124

4 Os Conceitos de Construção e Expressão 137

5 Conteúdo de Verdade, Arte como Escrita e Historiografia Inconsciente 140

6 Arte, Educação e Formação 147

Considerações Finais 160

Bibliografia 167 


\section{Introdução}

O presente trabalho pretende investigar algumas das articulações entre dois objetos tão amplos e complexos quanto o indivíduo e a obra de arte através de quatro conceitos fundamentais encontrados na obra de T.w. Adorno: cultura, emancipação, formação e arte.

Surgido do cruzamento das inquietações de um psicólogo, de formação, com um artista, por aspiração, e tendo de se materializar numa obra acadêmica que tanto siga os preceitos indispensáveis para sua constituição enquanto tal ao mesmo tempo em que se lhe faz uma crítica, exigida não só pelo pensamento do autor que nos orienta, mas do objeto mesmo de que trata o trabalho, este não poderia se dar sem contradições.

A primeira, e mais evidente, para nós, é a dimensão da pretensão da tarefa em contraposição ao tempo disponível para a elaboração de uma dissertação de mestrado e - por que não dizer - à formação do próprio autor: nem em filosofia, nem em artes, nem em educação (não que a formação acadêmica em qualquer uma dessas áreas fosse garantia). Sobre essa contradição só nos resta afirmar a consciência da insuficiência e pedir a licença da humildade.

Mesmo a nossa limitação - conduzir a investigação a partir de textos de Adorno -, é ampla "a perder de vista". Por isso nos limitamos ainda mais e priorizamos apenas alguns textos, os quais deixaremos bem claros no transcorrer de cada parte. Por outro lado, dessa escolha outras contradições emergem. Se já nos era pouco o tempo, e pouca a formação para uma consideração mais ampla dentro da obra de Adorno, com parte de nosso tempo ainda nos sentimos impelidos a nos dedicar a outros textos de outros autores: Kant, Schiller, Goethe, Benjamin e 
outros - autores dos quais estamos ainda mais distantes e que, exigiriam, talvez, uma formação ainda mais profunda, tanto em arte, como em filosofia, assim como na língua alemã, comum a todos eles. A compreensão de Adorno, sem sair de Adorno, seria, porém, a nosso ver, não apenas menos clara quanto mítica - afinal, era também com esses autores, e não apenas, que Adorno dialogava enquanto escrevia.

A língua é obviamente um entrave quando o método de investigação escolhido é a análise de textos em cuja língua original o pesquisador não é fluente. Para remediar isso nos ativemos, o tanto quanto foi possível, às notas de tradução dos termos essenciais, assim como, por vezes, o cotejamento com traduções para o inglês e para o espanhol. Assumir que a leitura de Adorno é impossível fora do alemão, como fazem alguns, seria um fetichismo do particular, que como veremos, é contrário ao pensamento do próprio Adorno. A teoria, apesar de sua imanência lingüística - muitas vezes desconsiderada, e à qual daremos grande atenção no presente trabalho -, possui um poder de abstração que transcende o particular, que diz respeito ao todo, à nossa sociedade - capitalista, administrada, individualista sem indivíduos - de forma mais ampla, que supera, em muitos sentidos, a particularidade da língua, da experiência e da sociedade alemãs. Ler Adorno no original é um desafio para o qual ainda não estávamos preparados - Almeida (2009) nos diz que é um desafio mesmo para os nativos em língua alemã, para quem o texto de Adorno muitas vezes soa como outra língua; já ler Adorno “apenas no original” seria não só um fetichismo quanto uma desconsideração pelo crescente estudo e trabalho de tradução desse autor no Brasil e em Portugal.

Adorno escreve num estilo paratático, avesso a definições, que privilegia a coordenação à subordinação, difícil de sintetizar, difícil de parafrasear, mas nem por isso caótico ou incompreensível; pelo contrário, a dificuldade de seu pensamento em nenhum momento é uma dificuldade artificialmente induzida, uma escrita cifrada; a dificuldade de sua compreensão, à parte da semiformação generalizada, reflete a complexidade dos fenômenos abarcados, os quais sob a aparente facilidade de uma exposição "lógica e hierarquizada" estariam falseados. Em O Ensaio como Forma (2003e [1958]), texto onde Adorno comenta, de certo modo, seu próprio estilo e método, ele nos diz: 


\begin{abstract}
A harmonia uníssona da ordem lógica dissimula a essência antagônica daquilo sobre o que se impõe. A descontinuidade é essencial ao ensaio; seu assunto é sempre um conflito em suspenso. Enquanto concilia os conceitos uns com os outros, conforme as funções que ocupam no paralelogramo de forças dos assuntos em questão, o ensaio recua diante do conceito superior, ao qual o conjunto deveria se subordinar, seu método sabe que é impossível resolver o problema para o qual este conceito superior simula ser a resposta, mas apesar disso também busca uma solução. (p. 35)
\end{abstract}

Na Dialética Negativa (2009 [1966]), Adorno desenvolve essas idéias com ainda mais fôlego; para nós, aqui, basta assinalar, por enquanto, que é essencial, na própria filosofia de Adorno, que o conhecimento não se feche em sistematização, mas que os conceitos, postos em constelação, permaneçam permeáveis ao que não se pode reduzir a conceitos.

Algo nesse sentido é o que tentamos fazer aqui ao escolher esses quatro conceitos centrais (cultura, emancipação, formação e arte): pô-los em constelação, sem deduzi-los uns dos outros, nem reduzir os fenômenos ao seu conceito.

Os conceitos de cultura e emancipação tiveram, de certo modo, uma anterioridade aos conceitos de formação e de arte; isso porque, em termos gerais, o conceito de cultura aparece como tão amplo e primeiro que remete à idéia que o homem fez de sua própria separação da natureza e da civilização, como ameaça por um lado e sacrifício necessário por outro. Essa separação, porém, não se deu de uma vez por todas e completamente; como tentamos mostrar, até hoje vivemos um desenvolvimento histórico dessa separação, nem sempre enquanto emancipação, e mesmo quando sob essa bandeira, repleta de contradições. O conceito de emancipação surge então como uma representação das possibilidades abertas pela história de separação da cultura frente à natureza e a civilização/autoconservação que permanece numa tensão entre liberdade e determinação. Os conceitos de formação e de arte dizem respeito, de certo modo, a duas manifestações da cultura em que a emancipação pôde se dar, ao menos como utopia, até hoje, e que contém, na utopia mesma, uma promessa de felicidade. E por último, esses dois conceitos, de formação e de arte, estão intrinsecamente conectados, pois tanto a formação tal qual pôde ser pensada na modernidade só foi possível numa cultura que tinha a arte como uma figura de destaque, e de relativa autonomia; quanto à arte, tal qual a pensamos atualmente, só foi possível em uma cultura em que a própria consciência e, portanto, o homem, também havia adquirido a possibilidade da autonomia. 
Diversos outros conceitos e temas surgiram a partir desses e ganharam consideração: natureza, barbárie, Indústria Cultural, esclarecimento, práxis, educação, mímesis, conteúdo de verdade etc. Estes certamente mereceriam, por si sós, outros trabalhos e outras constelações de conceitos a eles relacionados.

A hipótese que nos guia, se tivéssemos que reduzir a uma e central, diríamos que é a de que, apesar da tendência dominante de desaparecimento do sujeito e da arte autônomos, apontados por Adorno, sua própria teoria, ao fazer tal diagnóstico criticamente, já é parte da cura possível; que a crítica da formação e a crítica da arte, intrinsecamente conectadas, são uma práxis transformadora no caminho de uma emancipação de ambos.

Outro ponto, para alguns um detalhe, mas que para outros não deve ter passado despercebido, é a controversa palavra "através" no título. ${ }^{1}$ Para alguns, ela deve ser sempre usada em seu sentido de "passar por entre, atravessar" e nunca o de "por meio de" - este último, atualmente, já incorporado nos dicionários. A rigor, nenhum desses dois sentidos seria justo ao uso que dele fizemos. O primeiro porque daria um sentido de trajeto incólume, como um cachorro treinado que passa "através" de um arco de fogo sem se queimar; e o segundo porque daria um sentido utilitário, de ferramenta, como um recado passado "através" de um bilhete. O pensamento de Adorno, porém, dificilmente se deixa usar como ferramenta; alguém que o escolhesse com esse propósito só poderia ter algo de masoquista, com tantos pensamentos-ferramenta à disposição "no mercado", prontos para o uso. Ao mesmo tempo, só com muito esforço poder-se-ia passar incólume pelo seu pensamento; num mundo de semiformação generalizada, conseguir entender Adorno, ao menos em parte, com a paciência e o ritmo que este demanda, tão oposto à distração e ao narcisimo da sociedade atual, já é operar uma transformação, que, para ser evitada, seria necessário uma força ainda maior do que a que ele nos fala, a respeito do ouvinte de música ligeira em Sobre Música Popular : "para ser transformado em um inseto, o homem precisa daquela energia que eventualmente poderia efetuar a sua transformação em homem" (ADORNO, 1994b [1941], p. 146). Esses dois atributos negativos de seu pensamento - não se deixar reduzir a ferramenta, não se deixar passar por ele incólume - são também duas formas

1 Agradecemos ao professor Celso Favaretto pela feliz sugestão dessa palavra, que nos despertou para a interpretação aqui construída. 
de impedir o desaparecimento da dimensão do particular no sujeito e no objeto que o positivismo no discurso científico deseja e promove. Uma ferramenta pode ser usada por qualquer um, indistintamente, assim como indistinta se torna a própria ferramenta (substituível por qualquer outra que produza o mesmo resultado). Do mesmo modo, aquele que passa incólume é indistinto, e é indistinto aquilo pelo qual passou; já que nenhuma mudança se opera nessa travessia, as qualidades particulares do sujeito e do objeto são desprezíveis. O sentido que quisemos dar ao "através", no título, foi, ao contrário disso, o de passar pelo pensamento de Adorno sem indistingui-lo e sem indistinguir-nos, sem dominá-lo e sem se fazer dominar. Assim, vale a ressalva: nem tudo o que se pode encontrar aqui é Adorno, mas é nosso encontro com Adorno.

Duas notas finais precisam ainda ser registradas: 1. muitas vezes os textos por nós utilizados seguem uma norma de grafia que já não é mais a atual, assim como as traduções portuguesas também possuem diferenças de grafia em relação à norma brasileira - mantivemos todas as citações em português tais quais as encontramos no original; 2. toda vez que um texto base é citado, em sua primeira aparição em nosso trabalho, optamos por incluir a data de publicação e/ou escrita original (quando conhecida) entre colchetes logo após a data de publicação da edição por nós utilizada; não fizemos o mesmo com os comentadores visto que quase nunca o tempo transcorrido entre uma e outra supera uma década. 


\section{O Conceito de Cultura}




\section{Cultura e Civilização \& Cultura e Sociedade}

Jay (1988), importante historiador da Escola de Frankfurt, diz que a análise de Adorno da Cultura (Kultur, em alemão), levando-se em conta toda a complexidade desse conceito, é um dos motivos mais importantes para atrair a atenção da posteridade à sua obra, devido à sua extraordinária riqueza e variedade nesse tema.

Ainda segundo ele, Kultur apresenta "ressonâncias especiais" desde sua justaposição, no século XVIII, ao conceito de Zivilisation (Civilização). Seguindo essa pista, porém, podemos encontrar os dois conceitos no título de um verbete de Temas Básicos de Sociologia (1973a [1956]), escrito por Adorno, conjuntamente com Horkheimer, e constatar, logo de início, que essa contraposição é bem anterior ao século XVIII.

Nesse texto os autores investigam brevemente a origem das duas palavras na tradição ocidental, a partir de algumas das suas primeiras aparições conhecidas, ou suas correspondentes, ora no latim, ora no inglês, no francês e por fim no próprio alemão. ${ }^{2}$

Dessa investigação destacaremos apenas a consideração a respeito de Cícero, onde uma expressão usada para se referir à cultura - "interiorizada e neutralizada como cultura animi” - já torna possível entrever, segundo eles, algo do dualismo moderno entre cultura e civi-

2 Marcuse (1997 [1937]) remonta a contraposição entre a idéia de cultura e a idéia de civilização à filosofia clássica grega, em Platão e Aristóteles, mas no caso não se detém em uma consideração filológica. 
lização: “'Cultura' sempre teve uma conotação de 'cultura espiritual', enquanto que 'civilização' subentende um 'progresso material"' (ibid., p. 93).

Depois de apresentar uma série de conotações que colocam ambas as palavras em completa oposição, os autores ressaltam as concepções kantiana e freudiana, onde os dois conceitos aparecem interligados. Segundo eles, em Kant tais conceitos estão numa relação que "não é a da simples sucessão no tempo nem de mera incompatibilidade", mas “interdependentes" e até "contraditórios":

Ele sabe que não pode existir uma sem a outra; que o desenvolvimento interior do homem e a sua configuração no mundo externo dependem um do outro, sendo uma ilusão querer criar um mundo de interioridade que não desse provas de sua existência atuando sobre a realidade exterior. (ibid., p. 96)

Freud, por sua vez, também se opõe à distinção entre cultura e civilização, como se pode constatar em uma passagem de O Futuro de uma Ilusão, ${ }^{3}$ citada por eles:

A cultura humana - entendendo por isto toda a ascensão ocorrida na vida humana desde as suas condições animais pela qual se distingue da vida dos animais, e abstendo-me da insípida distinção entre cultura e civilização - mostra claramente dois aspectos a quem a observa. Por um lado, abrange todo o saber e capacidade que os homens adquiriram para dominar as forças da natureza e obter os bens que satisfazem as necessidades humanas; e, por outro lado, todas as instituições necessárias para reger as relações dos homens entre si e, mormente, a distribuição dos bens obtidos. Estes dois sentidos da cultura não são mutuamente independentes, primeiro, porque as relações recíprocas dos homens se modificam profundamente, na medida em que a satisfação dos impulsos se torna possível através dos bens disponíveis; segundo, porque o próprio indivíduo humano pode estabelecer com outro uma relação de homem a coisa, quando o outro utiliza sua força de trabalho ou é adotado como objeto sexual; terceiro, porque cada indivíduo é, potencialmente, um inimigo virtual dessa cultura que, entretanto, há de ser um interesse humano universal. (FREUD apud ADORNO; HORKHEIMER, 1973a [1956], p. 97)

Ao mesmo tempo em que os autores demonstram uma adesão a esse "esforço iluminista", de Kant até Freud, em evitar uma separação rigorosa que "abre portas" para a "barbárie”, eles apontam duas tendências contraditórias nessa separação muito importantes para o nosso trabalho:

A primeira delas é que nem sempre a separação entre cultura e civilização é algo prejudicial, que leva à barbárie. Segundo eles, “é um grande elogio chamar cultura tudo o que

3 FREUD, s. Die Zakunft einer Illusion (O Futuro de uma Ilusão). In: Gesammelte Werke, vol. XIv. Londres, 1940-1953 [1927], pp. 326 e segs. 
não se refere, com forma imediata, ao mecanismo da autopresevação" (ADORNO; HORKHEIMER, 1973a, p. 96). Isto é, apesar das duas estarem estreitamente ligadas, o movimento da história que possibilitou que se considerasse a cultura como algo que não se refere à autopreservação é um índice de liberdade adquirida pela cultura.

A outra tendência diz respeito ao fato dessa separação estar, na realidade, efetivamente ocorrendo, a despeito do esforço iluminista em evitá-la. A cultura, em nossa sociedade, está realmente cada vez mais separada da autopreservação; o que não significa que tenha adquirido liberdade em face desta, pelo contrário, a autopreservação é que se agigantou e deixou à cultura a insígnia do supérfluo: "A evocação da Cultura é impotente” (ibid., p. 98). Isto é, a completa liberdade da cultura é na verdade um índice de que a técnica vem se tornando dona “não só do corpo como do espírito dos homens" (ibid., p. 99).

Ao final desse texto, porém, os autores fazem uma aposta na civilização, separada da cultura, que consideramos destoante de todo o restante da obra de Adorno:

\footnotetext{
Esta hierarquia de finalidades absurdamente desvirtuada [ligada ao consumismo], a que ninguém pode esquivar-se, não será remediada por um retorno à substância da Cultura, que está destinado, de qualquer modo, a continuar sendo um retorno quimérico; sê-lo-á, outrossim, por um esforço para impelir a civilização, de forma positiva, num rumo em que ela própria se supere. O que toda a cultura nada mais fez, até hoje, do que prometer, será realizado pela civilização quando esta for tão livre e ampla que não exista mais fome sobre a Terra. (ibid., loc. cit.)
}

Chamar todo retorno à cultura como algo de quimérico, e associar toda liberdade a um desenvolvimento positivo da civilização não nos parece nem de completo acordo com o próprio texto - vide o trecho por nós trazido há pouco, no qual a liberdade da cultura frente à autopreservação é considerada um elogio.

Essa incongruência talvez seja mais um indício que dê suporte à tese sustentada por Hullot-Kentor (2006a) - com base, dentre outras coisas, em uma transcrição de conversa entre Adorno e Horkheimer - de que Adorno seria mais "otimista", que alguns caminhos tomados por este eram por vezes considerados ingênuos pelo colega. Se isso estiver correto, fica mais clara a diferença muitas vezes apontada pelos comentadores entre os textos escritos pelos dois 
em conjunto, em especial os contidos no livro Dialética do Esclarecimento (1985 [1944-1947]), e os escritos apenas por Adorno. ${ }^{4}$

Quanto a isso, porém, só podemos especular. O que nos cabe destacar é que essas duas tendências contraditórias apontadas acima - pendendo claramente para a segunda via, no referido texto - encontramos de forma mais dialética em outro texto escrito por Adorno em 1949, mas publicado em 51, Crítica Cultural e Sociedade (1998 [1951]).

Adorno começa esse texto com a aporia da "crítica cultural". Como pode alguém criticar a cultura que não de dentro dela?5 No momento mesmo em que critica "não consegue evitar a insinuação de que possui a cultura que diz faltar" (ibid., p. 7). Ao se criticar a cultura, sem se criticar o próprio conceito de cultura, mantém-se, no ato acusatório, seu conceito isolado e protegido.

Para Adorno, o conceito de cultura, ele próprio, é "o supremo fetiche" (ibid., p. 12). Fetiche, segundo Marx, é aquilo considerado pelo homem como tendo "vida própria"; "figuras autônomas", quando na verdade são produtos humanos. O fetiche da mercadoria, por exemplo, é quando esta é tomada apenas pela sua aparência no presente da vitrine (um objeto de determinadas qualidades, custa tanto) e o trabalhador, do outro lado do vidro, esquece-se de que o valor dela só existe em conexão com a exploração do seu trabalho - daí o caráter mágico do fetichismo: o encanto do esquecimento. Nas palavras de Marx:

[O fetiche da mercadoria] Não é mais nada que determinada relação social entre os próprios homens que para eles aqui assume a forma fantasmagórica de uma relação entre coisas. (MARX, 1982 [189o], p. 71)

Assim, identificar o conceito de cultura com o supremo fetiche é dizer que a cultura, acima de tudo, não pode ser tomada como uma coisa em si. "Aceitar a cultura como um todo", ele diz em outro momento, "já é retirar-lhe o fermento de sua própria verdade: a negação" (ADORNO, 1998, p. 19).

4 Quanto a esse último livro, Hullot-Kentor (2006a) põe em dúvida, inclusive, a idéia de uma autoria dupla harmônica, atribuindo a autoria principal ora a um ora a outro.

5 Aparentemente uma "contradição performativa”, como chamou Habermas (2002 [1985]) a crítica à razão feita por Adorno e Horkheimer na Dialética do Esclarecimento - crítica à razão "dentro" da razão. A nosso ver, a saída de Adorno para essa aporia a respeito da crítica cultural nos dá valiosos elementos para rejeitar a redução habermasiana da aporia do Esclarecimento à mera "contradição performativa". Para respostas possíveis à crítica feita por Habermas, ver o texto de Hullot-Kentor (2006a), já citado, e Silva (2005). 
Desse modo, a aporia da crítica cultural só não tem saída se a cultura for tomada dessa forma, fetichizada. Como para Adorno a cultura não é um todo homogêneo, e sim fragmentário, contraditório, ${ }^{6}$ por vezes apresentando um teor mais autônomo, por vezes mera confirmação de processos econômicos, a verdadeira crítica da cultura, para ele, aquela que não toma a cultura como um ídolo - "neutralizada e reificada" - é o que confere verdade também à cultura:

A cultura só é verdadeira quando implicitamente crítica, e o espírito que se esquece disso vinga-se de si mesmo nos críticos que ele próprio cria. A crítica é um elemento inalienável da cultura, repleta de contradições e, apesar de toda sua inverdade, ainda é tão verdadeira quanto não-verdadeira é a cultura. (ibid. p. 11)

Ou seja, considerada em sua dinâmica histórica, através da crítica, o conceito de cultura mostra suas diversas "caras". Na esteira das duas vias que apresentamos a respeito de Cultura e Civilização, uma via que vê a emancipação da cultura como um elogio (pois então esta não é mais mera autopreservação) ou como impotência (pois só a civilização pode realizar o que a cultura só pode prometer) - com uma ênfase, a nosso ver, desmedida, nessa última tendência; em Crítica Cultural e Sociedade, essas vias aparecerão do seguinte modo:

Pois nenhuma obra de arte autêntica e nenhuma filosofia verdadeira jamais esgotaram seu sentido em si mesmas, em seu ser-em-si. Sempre estiveram relacionadas ao processo vital real da sociedade, do qual se separaram. Justamente a renúncia à rede de culpa de uma vida que se reproduz cega e rigidamente, a insistência na independência e na autonomia, no rompimento com o reino estabelecido dos fins, implica, ao menos como elemento inconsciente, a

6 Porém, não é um todo contraditório essencialmente indeterminado, o que daria margem a um relativismo do tipo "se tudo é contraditório nada pode ser dito além de um ponto de vista, e, portanto, tudo pode ser dito”. Não, é contraditório e historicamente determinado, seria mais o seguinte: "muito pode ser dito, não se chegará a uma verdade última, mas não é qualquer coisa que pode ser dita”.

7 Reificar é, grosso modo, transformar em coisa, perder de vista o processo significado, para nossos propósitos, muito próximo ao de fetichismo; na verdade, sua contraparte. No capítulo 1 de O Capital, por exemplo, logo após Marx conceituar o fetichismo da mercadoria, ele diz que a inversão que este produz faz com que as relações entre as pessoas e seus trabalhos apareçam como "relações reificadas entre as pessoas e relações sociais entre as coisas” (MARX, 1982, p. 71). Ou seja, se o fetichismo é conferir vida autônoma às coisas, reificar é tratar como coisa, tirar a vida, do que é humano. Não entraremos também no terreno complicado da diferenciação entre reificação e coisificação (geralmente traduções, respectivamente, de Verdinglichung e Versachlichung); os quais usaremos como sinônimos. Para uma consideração a respeito, ver as notas dos tradutores em Adorno (1995a, pp. 245-247) e Adorno (2003a, p. 130). 
referência a uma situação na qual a liberdade seria realizável [ $1^{\mathrm{a}}$ via]. Mas a liberdade permanecerá uma promessa ambígua da cultura enquanto sua existência depender de uma realidade mistificada, ou seja, em última instância, do poder de disposição sobre o trabalho de outros [ $2^{\mathrm{a}}$ via]. (ibid., p. 12)

Fica mais claro, portanto, a "ambigüidade" dessa separação: se por um lado a cultura pode ser libertação ( $1^{\mathrm{a}}$ via), só o pode, por enquanto, no ideal, na utopia, nas possibilidades que abre, porque a liberdade ainda não foi realizada na sociedade; por outro lado, a cultura é impotente, é consolação ( $2^{\mathrm{a}}$ via) quando apresenta a utopia como já realizada - desse modo, ideologia - e serve como instrumento de manutenção das condições sociais de exploração e pobreza vigentes - ou, em outras palavras, mantém o sofrimento, quer como coerção, quer como sacrifício. A saída adorniana é justamente a crítica; por meio da crítica podemos evitar - ou ao menos, tentar - que a primeira via deságüe na segunda, que a utopia se cristalize enquanto ideologia, perdendo assim seu momento de verdade.

Mas vamos dar "nomes aos bois" - situar historicamente essas duas vias e suas contradições. Vejamos o que Adorno nos diz ainda nesse texto:

\footnotetext{
Assim como a cultura surgiu no mercado, no comércio, na comunicação e na negociação como algo distinto da luta imediata pela autopreservação individual; assim como ela se irmana, no capitalismo clássico, ao comércio; e assim como os seus portadores se incluem entre as 'terceiras pessoas' e se sustentam como intermediários; assim a cultura, considerada 'socialmente necessária’ segundo as regras clássicas, ou seja, algo que se reproduz economicamente, restringe-se novamente ao âmbito em que se iniciou, o da mera comunicação [...] A crítica cultural aponta para isso, reclamando contra a 'superficialidade' a 'perda de substância'. (ibid., p. 15)
}

Isto é, o mercado, o comércio, a comunicação, em especial no capitalismo, tornaram possível que a cultura fosse mais do que autopreservação, mas quando ela se reduz à economia, ela volta a ser novamente mera comunicação - perdeu a força de transformação sobre o mundo, virou ideologia.

Assim, simplificando ao máximo o movimento da cultura, e seu conceito, no decorrer da história, tal como pudemos depreender de nossa leitura de Adorno, poderíamos dizer que a burguesia (desde suas versões prototípicas) é que tornou possível a emancipação da cultura, porém sem emancipar a sociedade. A liberdade e a diferenciação na cultura, em contraste com a necessidade e a privação na sociedade, transformam a utopia em ideologia. Mantida a privação, 
a ideologia se torna a própria privação e dispensa até mesmo seu momento utópico. ${ }^{8}$ A crítica da cultura, ao denunciar a privação (da comida à razão) pode resgatar o momento de verdade na utopia. Possibilidade aberta logicamente, porém, em Adorno, as possibilidades lógicas são sempre só possibilidades, apenas o movimento real da história pode nos dizer qual se realizará. Entretanto, em 1951, apenas seis anos após o fim da Guerra, para Adorno, não era a possibilidade de resgate da utopia que parecia a mais próxima de se realizar (sequer parece próxima hoje), e sim a da aniquilação. Por isso, um texto onde tantas vezes emerge o caráter utópico da cultura, ao final, vai submergir no medo:

\footnotetext{
Quanto mais totalitária for a sociedade, tanto mais reificado será também o espírito, e tanto mais paradoxal será o seu intento de escapar por si mesmo da reificação. Mesmo a mais extremada consciência do perigo corre o risco de degenerar em conversa fiada. A crítica cultural encontra-se diante do último estágio da dialética entre cultura e barbárie: escrever um poema após Auschwitz é um ato bárbaro, e isso corrói até mesmo o conhecimento de por que hoje se tornou impossível escrever poemas. Enquanto o espírito crítico permanecer em si mesmo em uma contemplação auto-suficiente, não será capaz de enfrentar a reificação absoluta, que pressupõe o progresso do espírito como um de seus elementos, e que hoje se prepara para absorvê-lo inteiramente. (ibid., p. 26, grifo nosso)
}

Praticamente uma prescrição à poesia, “escrever um poema após Auschwitz é um ato bárbaro" é uma das frases mais polêmicas de Adorno, largamente usada por seus críticos. Como muito bem salientou Gagnebin (2009a), essa frase, no contexto desse texto, "ressalta muito mais a urgência de um pensamento não harmonizante, mas impiedosamente crítico - isto é,

8 Ou seja, tampouco o conceito de ideologia é um fetiche, para Adorno. Segundo ele, na era burguesa a ideologia era uma teoria; hoje, quando "quase não há mais teoria”, a ideologia “é como o ruído produzido pelas engrenagens da práxis inexorável” (ibid., p. 20). Para Adorno, a ideologia, como a cultura, não é sempre uma e mesma, se na era burguesa ela se dava enquanto teoria (da igualdade, da liberdade), hoje, em que a consciência foi demitida do processo de produção, a própria realidade assume o lugar da teoria na manutenção da falta de liberdade e na má diferença (a da exploração e do sofrimento). A seguinte passagem é emblemática: "A ideologia, ou seja, a aparência socialmente necessária, é hoje a própria sociedade real, na medida em que o seu poder integral e sua inexorabilidade, a sua irresistível existência em si, substitui o sentido por ela própria exterminado" (ibid., p. 22). 
a necessidade da cultura enquanto instância negativa e utópica” (p. 72) do que um diagnóstico pessimista e intolerante. ${ }^{9}$

Seligmann-Silva (2009) defende algo semelhante, e tanto ele quanto Gagnebin (2009a) remetem a diversos outros momentos na obra de Adorno em que essa asserção será retomada, reafirmada, matizada, mas nunca negada. Já a respeito de outra afirmação de Adorno, no mesmo sentido e igualmente polêmica, de que "toda cultura depois de Auschwitz, inclusive a sua urgente crítica, é lixo" (ADORNO, 2009, p. 304), Duarte (1993) recorre ao mesmo argumento de Robert Schurz ${ }^{10}$ sobre o exagero enquanto método de "driblar a desgraça":

Só a radicalidade dessas sentenças possibilita aquela Minima Moralia: Adorno pretende iludir a desgraça, designando-a com excesso, porque a diferença, que assim se constitui, deixa lugar para a própria ação. (sCHURZ apud DUARTE, 1993, pp. 99-100)

Reconhecemos que este argumento tem sua justificação, em especial se lembrarmos o trecho da obra invocada, Minima Moralia, sobre o exagero:

9 Ainda segundo Gagnebin (2009a), “Auschwitz”, no pensamento de Adorno, será um “emblema do intolerável”, trazendo uma dimensão ética que não se subordinará nem a uma "postura estética, nem a uma sistemática especulativa”. Que essa “instância ética”, nascida frente ao horror (sofrimento), "comandará suas reflexões estéticas” (p. 74). Posição que compartilhamos.

Safatle (2009) apresenta uma objeção a essa posição, segundo ele, "posição de quem se desespera”, pois "nenhuma filosofia pode ser solidária com um acontecimento meramente negativo (evitar algo, impedir que algo aconteça novamente etc). Toda verdadeira filosofia traz consigo a exigência de pensar a partir de um acontecimento portador de promessas instauradoras" (p. 173). Ainda segundo ele, a posição criticada seria "uma filosofia assombrada pelo caráter totalitário do uno" (p. 172), e que "toda sua filosofia [de Adorno] é a elaboração contínua e rigorosa das potencialidades abertas pelas expectativas vanguardistas da estética musical" (p. 173, grifo nosso). Acreditamos que Safatle, no referido texto, tenha perdido de vista, por um momento, as marcas deixadas pela história na teoria, e gostaria de erigir uma teoria mais independente da sociedade (e sua história) do que, a nosso ver, Adorno tentou defender. Este não se cansou de dizer, em diversos momentos, que um conceito não se reduz àquilo que o originou. Poderia ser sua teoria toda apenas uma "elaboração contínua" das possibilidades abertas pela vanguarda da música? Dizer isso é o mesmo que dizer que sua teoria seria a mesma com ou sem o advento de Auschwitz; o que, a nosso ver, isso sim, é um fantasma idealista do caráter totalitário do uno. Não desprezando aqui, de forma alguma, a centralidade da experiência da vanguarda musical na teoria adorniana, porém, a mesma sociedade - contraditória - que produziu essa vanguarda, produziu seus perseguidores e produziu Auschwitz; tanto este quanto aquela fazem parte de um fenômeno mais amplo, que não podemos perder de vista. Acreditamos que a experiência de vanguarda da música tem uma centralidade sim, no pensamento de Adorno, desde que essa seja a co-centralidade de uma estrela em sua constelação. 
Ele [o pensamento] exprime com exatidão o que é, pelo fato mesmo de que o que é nunca é inteiramente tal qual o pensamento o exprime. A ele é essencial um elemento de exagero, que o impele para além das coisas e o faz desembaraçarse do peso do factual [...]. (ADORNO, 1992 [1944-47], p. 110, grifo nosso)

Pensamos, porém, que "driblar" ou "iludir a desgraça" não sejam boas expressões, pois estas remetem a algo de um esquecimento da desgraça, ou um embuste, um golpe de astúcia, enquanto a obra de Adorno, assim como a de Benjamin, dá à relação necessária com a desgraça outra conotação. Minha pequena contribuição, nesse debate, seria lembrar outro trecho muito famoso a propósito de Auschwitz, com respeito à educação (e sua finalidade necessária após Auschwitz), mas que ousaria estender à arte e à filosofia:

[...] o medo não deve ser reprimido. Quando o medo não é reprimido, quando nos permitimos ter realmente tanto medo quanto esta realidade exige, então justamente por essa via desaparecerá provavelmente grande parte dos efeitos deletérios do medo inconsciente e reprimido. (ADORNO, 2003b [1967], p. 129)

A nosso ver, o que incomoda os críticos de Adorno em frases como "escrever um poema após Auschwitz é um ato bárbaro" é que ela não reprime o medo. O medo aparece com toda sua força sem, no entanto, ser desespero, sem que o pensamento se entregue à paralisação frente ao medo - como temem alguns críticos que se paralisam só de pensar em levar a sério asserções como essa. O medo é invocado, o horror é dito em voz alta para que possamos elaborá-lo. A filosofia de Adorno não precisa ser homogênea, conter a cada frase o todo, de modo que o medo, no todo, apareceria sempre com sua função delimitada, apaziguado, em função do progresso. Adorno também não fetichiza o medo.

Já entramos com isso, entretanto, em outra esfera de conceitos que se contrapõem à cultura e que merecem uma consideração mais detida.

\section{Cultura e Natureza \& Cultura e Barbárie}

Cultura, natureza e barbárie são três conceitos onipresentes quando se trata de Teoria Crítica, o que, por isso mesmo, torna tão difícil sua abordagem e exposição. O caminho mais óbvio, talvez, é lembrar a primeira frase da Dialética do Esclarecimento, na qual os autores nos 
dizem que este, o esclarecimento, pretendia colocar os homens na "posição de senhores", mas os ameaça, entretanto, com uma "calamidade triunfal".

O esclarecimento, nesse contexto, representa o movimento da cultura em que esta pretendia libertar os homens do domínio da natureza, mas que, porém, da forma como se deu em nossa história, acarretou em mais domínio sobre o próprio homem, em barbárie.

No texto citado, em especial no primeiro capítulo e no Excurso I, os autores expõem a famosa tese de que o mito já era esclarecimento e o esclarecimento acabou por se reverter em mitologia, assim como analisam a aventura de Ulisses na Odisséia - texto fundador da cultura ocidental - como a proto-história do sujeito, na qual este, para se formar, teve que se subtrair ao poder da natureza - externa e interna - pagando como preço o próprio sacrifício.

Existe uma ampla literatura em língua portuguesa comentando esses dois textos e os expondo em maiores detalhes, por isso nos absolvemos dessa tarefa. No momento, achamos mais fértil retroceder a dois textos anteriores à Dialética do Esclarecimento para nos aprofundar no assunto. O primeiro, do próprio Adorno, A Idéia de História Natural (2008a [1932]), e o segundo de Benjamin, Sobre o Conceito de História (1996b [1940]), mais especificamente sua tese número viI.

No primeiro texto, Adorno se coloca contra a separação habitual entre natureza e história, ${ }^{11}$ em que a natureza seria algo de pré-científico, a espera de ser transformado em objeto das ciências naturais matemáticas. Adorno - novamente, na contramão da fetichização dos conceitos - diz que os conceitos de natureza e história não podem ser entendidos "como definições essenciais válidas desde sempre", e que sua intenção é levá-los "até um ponto em que a mera separação entre eles seja superada”. (ADORNo, 2008a). O conceito de natureza, Adorno o associa ao de mítico:

Por ele (mítico) se entende o que está aí desde sempre, o que sustenta a história humana e nela aparece como um ser anteriormente dado, submetido inexoravelmente, o que nela há de substancial. (ibid., grifo nosso)

E ao conceito de história associa o de novo:

11 Para nossos objetivos, o conceito de história, nesse texto, pode ser entendido como um sinônimo de cultura. 
[...] história designa uma forma de conduta dos homens, forma de conduta transmitida, que se caracteriza antes de tudo pelo fato de aparecer nela o qualitativamente novo, por ser ela um movimento que não se desenvolve na pura identidade, na pura reprodução do que sempre esteve aí, e sim produz o novo e alcança seu verdadeiro caráter através do que nela, aparece como novo. (ibid., grifo nosso)

Note que em ambos os trechos citados o verbo utilizado é "aparecer" (erscheinenden): o mítico é aquilo que aparece enquanto dado desde sempre, e a história é aquilo que aparece enquanto novo; o que quer dizer que não é uma verdade completa, que o mítico não está lá desde sempre, nem a história é completamente nova, mais o fato de aparecerem como tal contém uma verdade. Assim como a ideologia, a aparência ${ }^{12}$ nunca é completamente falsa, ela contém um momento de verdade que precisa ser considerado:

[...] o momento da realidade da aparência frente ao seu caráter simbólico: que em todo lugar onde nos defrontamos com a aparência, a sintamos como expressão, como algo não apenas aparente que se deixa de lado, e sim que expresse algo que aparece nela e que não pode ser descoberto independentemente dela. (ibid.)

Mas por que a natureza apenas aparece como dado e a história apenas aparece como novo? Para responder a esta pergunta Adorno recorre a Lukács e Benjamin. No primeiro, busca o conceito de segunda natureza. ${ }^{13}$ Segundo Lukács, na Teoria do Romance (2000 [1916]), a primeira natureza seria aquela que pode ser conhecida pelas ciências, que se conforma a leis; conhecimento, porém, que só se dá por essa conformidade, não em sua “verdadeira substância”. Já a segunda natureza, igualmente inapreensível em sua verdadeira substância, é o mundo da convenção, dos costumes: "é um complexo de sentido petrificado que se tornou estranho" (p. 64)

12 Concepção à qual retornaremos diversas vezes no decorrer deste trabalho. Como introdução, destacamos o que diz Mazzari (BENJAMIN, 2009a), em nota a respeito do termo "aparência" no ensaio As Afinidades Eletivas de Goethe escrito por Benjamin: "Empregado inúmeras vezes ao longo deste ensaio, o termo 'aparência' corresponde no original a Schein, substantivo masculino que também significa 'brilho'. Do mesmo modo, o verbo scheinen pode ser traduzido tanto por 'parecer' ou 'aparentar', quanto por 'brilhar', 'reluzir'. Ao campo semântico de Schein pertence, portanto, não só a conotação negativa de 'ilusão, aparência enganosa', mas também a de manifestação sensível, fenomênica, relacionada à Erscheinung, isto é, 'aparição' (phainomenon, em grego).” (p. 13)

13 Duarte (1993) aponta a respeito do conceito de segunda natureza em Adorno também seu fundamento anterior a Lukács, o da Filosofia do Direito de Hegel, onde o costume e o hábito são chamados por este de segunda natureza. 
e estrutura o homem como um "conteúdo sedimentado". ${ }^{14}$ Isto é, a natureza apenas aparece como dado (primeira natureza) porque parte dela não é dada desde sempre, mas constituída historicamente e sedimentada na cultura (segunda natureza), apenas aparecendo como natureza (primeira):

\footnotetext{
O que Lukács contempla é a transformação do histórico, enquanto o "passado" (tem-sido/Gewesen), em natureza, a história paralisada é natureza, ou o vivente paralisado da natureza é um mero ter-sido histórico. (ibid.)
}

O problema de Lukács, para Adorno, é o teor teológico que ele confere ao problema, se está correto em dizer que o histórico é também natureza, falta-lhe o contraponto dialético: a natureza também é histórica - noção que Adorno, busca então em Benjamin. Adorno cita duas passagens significativas de Origem do Drama Trágico Alemão (2004 [1925]), das quais destaca a noção de transitoriedade da natureza: “A natureza flutua sobre eles (os escritores alegóricos) como trânsito eterno, no qual apenas o olhar saturnino destas gerações reconhecia a história" e "Se com a tragédia a história caminha para dentro do cenário, ela o faz como escrita. Sobre a máscara da natureza se encontra a 'história' na escrita cifrada do trânsito" (BENJAMIN ${ }^{15}$ apud ADORNO 2008a). Ou seja, a natureza ao se apresentar como transitória é, com isso, história. Nas palavras de Adorno:

\footnotetext{
A natureza mesma é transitória. Dessa maneira, tem em si mesma o momento da história. Sempre que aparece historicamente, o histórico remete ao natural, que nele passa. Ao contrário, sempre que aparece como "segunda natureza", esse mundo da convenção, que chega até nós, se decifra pelo fato de sua transitoriedade se tornar clara como significado. (ADORNO, 2008a)
}

Essa tensão dialética entre natureza (primeira e segunda) e história é o que permite Adorno dizer, ao final do texto, que "a Segunda natureza é na verdade a primeira" (ibid.), e com isso cumprir o que prometeu a princípio, que tentaria superar a separação entre natureza e his-

14 Veremos em outro momento como Adorno se utilizará da idéia de conteúdo sedimentado a respeito da relação entre as obras de arte e a história.

15 Benjamin, w. Ursprung des deutschen Trauerspeils. Berlim, 1928. p 178. As três diferentes datas de Origem do Drama Trágico Alemão se referem: 2008, ano de publicação em Portugal da edição por nós utilizada; 1925, ano de escrita do livro; 1928, ano de publicação da edição citada por Adorno. 
tória. Isto é, a natureza é histórica, e se algo aparece como natureza ou como história em nossa sociedade não é sem motivo, isso tem um significado nessa sociedade, diz sobre a sua história.

Para deixar mais claro lembremos o conceito de alegoria, desenvolvido por Benjamin na obra citada há pouco, o qual Adorno também aborda em seu texto. O conceito de alegoria em Benjamin não pode ser confundido com o que, segundo Adorno, habitualmente se denomina de alegoria: "a apresentação sensorial (mediante elementos sensoriais) de um conceito" (ibid.), e que por isso é geralmente considerada como abstrata e casual. Para Benjamin, alegoria é expressão: “[a alegoria] não é uma retórica ilustrativa através da imagem, mas expressão como a linguagem, e também a escrita" (BENJAMIN, 2004, p. 176).

Em outro texto, Benjamin explicita o que ele entende sobre a relação entre linguagem e expressão, o que vai nos ajudar a entender essa comparação entre linguagem e alegoria:

\begin{abstract}
Só pode afirmar-se que, nesta terminologia, qualquer expressão, desde que seja comunicação de um conteúdo intelectual, é considerada linguagem. E, todavia, segundo a mais completa e íntima essência, a expressão só pode ser entendida como linguagem; por outro lado, para se compreender uma essência lingüística temos sempre que nos interrogar sobre qual a essência espiritual de que ela é expressão imediata. Isto é, a língua alemã, por exemplo, não é de modo algum a expressão de tudo o que - supostamente - podemos exprimir através dela, mas sim a expressão imediata do que nela se transmite. (BENJAMIN, 1992b [1916], p. 178)
\end{abstract}

Isto é, não existe uma essência separada da linguagem que ganha expressão através ${ }^{16}$ dela, mas que poderia ser expressa de diversas outras maneiras. A expressão ocorre nela, na linguagem, o que leva Benjamin a dizer que "todas as linguagens se comunicam a si mesmas" (ibid., p. 179); aquilo sobre o que falam faz parte delas.

O mesmo é dito na Origem do Drama sobre a alegoria:

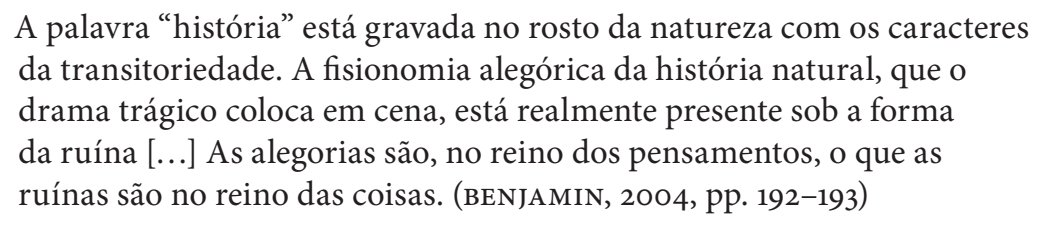

A alegoria, tal como aparece na Origem do Drama, por exemplo, não está no lugar de algo, não ilustra algo de forma puramente convencional. Para Benjamin, aí está o mais curio-

16 A palavra "através” aqui, não está no sentido que tentamos dar a ela na Introdução, mas no sentido entre o de trajeto incólume e o de instrumento. 
so da alegoria, ela é ao mesmo tempo convenção e expressão. ${ }^{17}$ Tem algo de convencional, mas não é substituível sem perda de sentido, ela "não é apenas signo do objecto a conhecer, mas em si mesma objecto digno de conhecimento" (ibid., p. 200). Como diz Adorno, “o tema alegórico é simplesmente história” (ADORNO, 2008a).

Esse é o também chamado caráter escritural da cultura, presente na teoria da linguagem de Benjamin. Segundo Seligmann-Silva (2009):

Sua teoria da alegoria [...] é também a teoria do funcionamento escritural da cultura, da cultura como memória: afinal, a alegoria é caracterizada por ser um traço, uma escritura cifrada na qual não apenas lemos testemunhos das gerações passadas, mas com a qual tentamos montar nosso presente [...] uma escritura que encapsula um determinado agora (tempo-do-agora, Jetztzeit) que pode brotar em outro agora (agora da cognoscibilidade, Jetzt der Erkennbarkeit), que lhe é análogo e que soube devolver a sua mirada no "momento correto". (pp. 130-131)

Não vamos entrar em maiores detalhes sobre o que mais especificamente da história as alegorias no barroco alemão expressavam, objeto de extensa análise por parte de Benjamin no trabalho citado, e que fugiria dos nossos propósitos. Mencionaremos apenas uma pequena curiosidade, que muito nos impressionou, sobre a influência da alegoria do barroco alemão na ortografia moderna da língua.

Quem quer que tenha tido contato com a língua alemã deve alguma vez ter se perguntado por que nela os substantivos são sempre escritos com inicial maiúscula. Vejamos o que ele nos diz:

Foi o Barroco que instituiu o uso das maiúsculas na ortografia alemã. Nisso se revela, não apenas a vontade de pompa, mas também o princípio da fragmentação e da dissociação, próprio do ponto de vista alegórico. Sem dúvida, muitos dos substantivos escritos com maiúscula ganharam desde logo um sentido alegórico para o leitor. A língua estilhaçada deixou de ser, nos seus fragmentos, mero instrumento de comunicação, e, objecto recém-nascido, coloca a sua nova dignidade ao lado de deuses, rios, virtudes e figuras da natureza semelhantes, todas elas reverberantes de sentidos alegóricos. (ibid., p. 229)

17 Gagnebin (2009c) chama isso de "historicidade filológica" de Benjamin, já presente no seu texto de juventude sobre o romance de Goethe, As Afinidades Eletivas. Ela nos diz, citando também Benjamin: "na esteira dos irmãos Grimm, 'nunca considerar os teores materiais (Sachgehalte) independentemente das palavras que os exprimem', não postular sentimentos, valores, princípios, em suma, conteúdos eternos, mas sempre diferenciar historicamente como algo determinado se diz e como depois, ao ser dito de outra maneira, esse 'algo' não é mais o mesmo” (p. 144). 
Ou seja, os autores barrocos escreviam peças em que os personagens eram por vezes a Castidade ou a Fortuna, por exemplo, e isso ficou na língua e não é casual, representa um desejo de conferir dignidade à própria língua, que passava pelo momento de sua unificação. Algo semelhante se dá em português, por exemplo, na norma corrente de se escrever Deus sempre com inicial maiúscula; o que pode parecer apenas uma convenção, expressa a história religiosa da escrita em português.

Em outro momento retomaremos essa noção, a propósito das obras de arte. Voltemos agora aos conceitos de natureza, cultura e - acrescentemos também - o de barbárie, como nos havíamos proposto.

Na tradição da filosofia alemã, barbárie significa o extremo oposto ao que o homem pode chegar em termos de anti-civilizado e que, ao mesmo tempo, não significa recair na natureza. Schiller, quem retomaremos a propósito do conceito de formação, por exemplo, nos diz:

[O homem] pode, por duas maneiras, viver em oposição a si mesmo: como selvagem, quando seus sentimentos imperam sobre seus princípios, ou como bárbaro, quando seus princípios destroem seus sentimentos [...] O homem bem formado faz da natureza sua amiga e respeita sua liberdade, na medida em que apenas põe rédeas a seu arbítrio. (SCHILLER, 2009a [1794-1795], p. 46)

Na filosofia de Schiller, que deve muito à de Kant, como veremos, a lacuna entre a natureza e a cultura ${ }^{18}$ é preenchida pela estética, que daria materialidade ao espiritual e espírito à matéria. Uma oposição bem marcada na obra de Kant, a princípio, entre o reino da natureza de um lado - que chega até nós pelos sentidos e que submetemos ao nosso entendimento - e o reino da liberdade de outro - dos princípios morais e religiosos, que submetemos à razão -, ganha outro significado com a inserção do reino da estética, já presente em Kant, mas redimensionado em Schiller. Só o homem, no seu estado estético, participaria tanto do reino da natureza quanto do reino da liberdade, e assim, estaria em "oposição a si mesmo" quando qualquer uma das duas esferas tentasse prevalecer, violentasse a outra. Seria um selvagem quando fosse mais natureza que liberdade, e seria um bárbaro quando sua liberdade violentasse a natureza.

18 Lacuna esta, nos diz Gagnebin (2005c), presente na história da filosofia ocidental desde, pelo menos, o abismo entre physis e nomos, na discussão entre Platão e a sofística (p. 175). 
A primeira frase da Dialética do Esclarecimento, que evocamos no início dessa parte, nada mais é que esse par de oposição "natureza/barbárie" schiller-kantiano, liberado do idealismo presente no conceito kantiano de liberdade. Novamente:

\begin{abstract}
No sentido mais amplo do progresso do pensamento, o esclarecimento tem perseguido sempre o objetivo de livrar os homens do medo e de investi-los na posição de senhores. Mas a terra totalmente esclarecida resplandece sob o signo de uma calamidade triunfal. (ADORNO; HORKHEIMER, 1985, p. 19)
\end{abstract}

Isto é, a liberdade não adviria de nenhum princípio extra-natural, mas seria o próprio progresso do pensamento que daria liberdade ao homem frente à natureza. Porém, o progresso do pensamento, o esclarecimento - tal como é apresentado ao longo da obra citada, como se sabe - acabou por significar um julgo sobre o homem tão grande quanto o era a natureza, ou pior.

Marcuse (1997), no mesmo sentido, relaciona a separação kantiana entre natureza e liberdade com a separação cartesiana entre corpo e alma, e chega, do mesmo modo, ao tema da barbárie:

Existe um cerne de verdade na afirmação segundo a qual o que acontece com o corpo não pode afetar a alma. Mas esta verdade assumiu uma forma terrível na ordem vigente. A liberdade da alma foi utilizada para desculpar miséria, martírio e servidão. (p. 108)

Em outro momento Adorno (2003j [1965]) explica da seguinte forma o que entende por barbárie:

Com barbárie não me refiro aos Beatles, embora o culto aos mesmos faça parte dela, mas sim ao extremismo: o preconceito delirante, a opressão, o genocídio e a tortura; não deve haver dúvidas quanto a isto. (p. 117)

Assim, em resumo, o termo barbárie significa para a Teoria Crítica violência; violência contra a natureza, inclusive a humana.

Com isso, até aqui, vimos como o conceito de natureza e cultura estão interligados e como a barbárie é violência contra a natureza, e portanto, contra a cultura - já que a cultura é natureza humana. Agora, fecharemos ainda mais o círculo de relações entre esses três termos com uma famosa passagem do último texto de Benjamin, Sobre o Conceito de História (1996b): 


\begin{abstract}
Pois todos os bens culturais que ele vê têm uma origem sobre a qual ele não pode refletir sem horror. Devem sua existência não somente ao esforço dos grandes gênios que os criaram, como à corvéia anônima dos seus contemporâneos. Nunca houve um monumento da cultura que não fosse também um monumento da barbárie. E, assim como a cultura não é isenta de barbárie, não o é, tampouco, o processo de transmissão da cultura. Por isso, na medida do possível, o materialista histórico se desvia dela. (p. 225, grifo nosso)
\end{abstract}

A palavra em alemão usada por Benjamin e traduzida na edição brasileira por "monumento" é Dokument. O mesmo trecho, na edição de Portugal, a tradução foi mais literal quanto ao substantivo: "Não há nenhum documento da cultura que não seja também documento de barbárie" (BENJAMIN, 1992c [1940], p. 161). Porém traduziu es ist niemals por "não há", enquanto o "nunca houve" da edição brasileira, caberia melhor, a nosso ver. Em Seligmann-Silva (2009) encontramos uma versão mista: "nunca existiu um documento da cultura que não fosse ao mesmo tempo um [documento] da barbárie" e a instigante tradução do próprio Benjamin para o francês:19 "Tout cela [l’héritage culturel] ne témoigne [pás] de la culture sans témoigner, em même temps, de la barbárie" (p. 51). Isto é, em tradução livre: "Toda herança cultural não testemunha a cultura sem testemunhar, ao mesmo tempo, a barbárie”.

À parte de tais variações, podemos notar que o sentido central se mantém. Todo monumento/documento/herança da cultura ser/testemunhar também um monumento/documento/herança da barbárie significa que até hoje, na história do homem, a cultura e seus bens, que deveriam estar ligados à liberdade e à felicidade, sempre trouxeram consigo como sombra um horror, a corvéia (trabalho compulsório) dos anônimos - portanto, violência. É bom frisar esse caráter histórico e relativo, a nosso ver, da sentença benjaminiana, para não se cair no erro de achar que o diagnóstico histórico é uma atribuição ontológica da barbárie à cultura. Por isso achamos válido colocar uma citação mais extensa - não apenas o trecho mais conhecido em negrito. Nela evidencia-se esse caráter histórico já representado na frase ilustre pelo "nunca houve" ou "nunca existiu" (aqui o "não há", da tradução portuguesa, a nosso ver, foi infeliz), ou seja, que Benjamin via uma possibilidade, ainda que limitada de se escapar da cultura como barbárie, já que o materialista histórico, "na medida do possível" pode se desviar dela. 
Apesar dessa frase se encontrar no último texto de Benjamin, na tese viI, de Sobre o Conceito de História, segundo Gagnebin (2009c) ela já aparece em um ensaio de 1937, encomendado por Adorno e Horkheimer para a Revista de Pesquisa Social, sobre Eduard Fuchs - "historiador e colecionador próximo da social democracia alemã, na época também exilado em Paris" (p. 151). O que elucida ainda mais o sentido dela, pois, esse ensaio, mais claramente que as Teses, segundo a autora, tecem uma crítica à concepção de cultura do materialismo histórico ortodoxo como acumulação de bens em prol da causa do proletariado.

O debate em questão para Benjamin, a autora nos situa, é sobre a herança (Erbe) cultural do passado. Em sua crítica ao expressionismo, Lukács havia rejeitado as vanguardas e defendido uma retomada da herança clássica. Benjamin se inclui entre aqueles que se opõem a essa concepção de cultura considerada como um "grande armazém de bens culturais" ou um museu, no qual partes do passado podem ser escolhidas e guardadas abstratamente como propriedades - em outras palavras, fetichizadas. Vejamos um trecho desse ensaio sobre Fuchs ${ }^{20}$ traduzido pela autora:

\footnotetext{
Se, para o materialismo histórico, o conceito de cultura é um conceito problemático, sua decomposição em um conjunto de bens que seriam para a humanidade objeto de propriedade, essa é uma representação que ele não pode assumir. A seus olhos, a obra do passado não é acabada. Ele não pode considerar nenhuma obra, em nenhuma parte, como cabendo para uma época enquanto disponível sem mais. Como um conjunto de formações consideradas independentemente, senão do processo de produção, do qual nasceram, mas no entanto do processo, na qual elas perduram, o conceito de cultura tem uma aspecto fetichista. A cultura aparece aí reificada. Sua história não seria nada afora a sedimentação formada por coisas memoráveis que se acumularam na consciência dos homens sem nenhuma experiência autêntica, isto é, política. (BENJAMIN apud GAGNEBIN, 2009c, p. 154)
}

Em suma, o que queremos destacar é que, assim como vimos há pouco que não podemos fetichizar o conceito de cultura, tomando-o por emancipado, desde sempre e para sempre, da natureza, pois ele também é natureza, e sua relação dialética de identificação e separação desta está sujeita às mudanças históricas; vimos agora que não podemos fetichizar o conceito de cultura como algo livre da barbárie, que essa relação também é histórica, e que até hoje, mas não necessariamente no futuro, cada monumento e cada documento, cada obelisco levantado e 
cada romance publicado existiu graças à manutenção do sofrimento humano, em especial, do trabalho compulsório ou do sacrifício voluntário que os produziu, direta ou indiretamente. ${ }^{21}$

Se quiséssemos continuar explorando o conceito de cultura pelo viés da Teoria Crítica, ainda teríamos à nossa frente pelo menos dois tópicos, interligados aos anteriores, que consideramos indispensáveis, o caráter afirmativo da cultura, tal como encontramos em Marcuse (1997) e o conceito de Indústria Cultural, tal como formulado por Adorno e Horkheimer (1985). Porém, o exposto até aqui nos evoca de tal modo os conceitos de emancipação, formação e arte que optamos por dar ao último apenas uma rápida introdução e guardar o primeiro - até mesmo porque soaria um tanto repetitivo, a princípio - para uma breve comparação com a Teoria Estética, na parte IV.

\section{O Conceito de Indústria Cultural}

Se um conceito surgido na Teoria Crítica se tornou um fetiche, não só no meio acadêmico, mas também na imprensa ou nos círculos esclarecidos, esse conceito é o de Indústria Cultural. Porém, Hullot-Kentor (2008) nos alerta que o sentido mais corrente atribuído a essa expressão, como se a cultura fosse mais um objeto da indústria dentre outros - a indústria de automóveis, a indústria de base... e a indústria cultural - não é aquele intentado por seus autores. O conceito de Indústria Cultural é antes de tudo o diagnóstico de um paradoxo social, um paradoxo inscrito no próprio termo designatório (Kulturindustrie, em alemão) ${ }^{22}$; é um conceito crítico, e não descritivo, como em sua versão fetichizada, no qual os antagonismos sociais apa-

21 O seguinte trecho do verbete Cultura e Civilização de Temas Básicos da Sociologia (1973a) também ecoa a afirmação de Benjamin: "é preciso meditar sobre a sorte dos escravos que ergueram as obras em que a cultura egípcia floresceu, e que é uma cultura ainda hoje celebrada, ou a das massas medievais, sem cuja mísera existência as catedrais góticas não poderiam ter sido edificadas [...]” (p. 98).

22 Hullot-Kentor (2008) associa o Kulturindustrie de Adorno a diversos outros paradoxos famosos na literatura: "o fogo frio de Shakespeare, a permanência fugitiva de Quevedo, os anões gigantes de Vitor Hugo, a abundância pobre de John Donne, o sol negro de Baudelaire, a dor prazerosa de Spencer, o pálido fogo de Nabokov, o humildemente audacioso de Oliver Swift [...]" (p. 20). 
recem apaziguados ideologicamente. O mesmo comentador descreve, em certo momento, esse paradoxo da seguinte maneira:

[...] a cultura, embora possa ter outros sentidos, é tudo aquilo que é mais do que autopreservação. É aquilo que surge da capacidade de suspender seus propósitos diretos. A indústria, força moderna por excelência, que - como todos sabemos - poderia ser ela mesma uma força da cultura, com a capacidade de dar fim à carência e ao sofrimento, limita-se, no imperativo de seu conceito de trabalho sistemático, nascido no século XVII, a excluir tudo que não seja propósito direto [...] A indústria cultural, como aquilo que poderia ir além, e que de fato vai além, da autopreservação da vida é reduzido à violenta luta pela sobrevivência. (p. 22)

Ou seja, se uma das coisas que definia a cultura no decorrer da nossa história, como vimos, foi sua separação da autopreservação (da civilização, da indústria), com todas as contradições que essa separação implica, a partir do momento em que se torna mera indústria fica ratificada a má junção, tal como denunciada por Adorno e Horkheimer em Cultura e Civilização: a cultura se torna impotente.

Vejamos um trecho da Dialética do Esclarecimento, na qual o termo foi cunhado, a esse respeito:
A unidade evidente do macrocosmo e do microcosmo demonstra para os homens o modelo de sua cultura: a falsa identidade do universal e do particular. Sob o poder do monopólio, toda cultura de massas é idêntica, e seu esqueleto, a ossatura conceitual fabricada por aquele, começa a se delinear [...] A verdade de que não passam de um negócio, eles a utilizam como uma ideologia destinada a legitimar o lixo que propositalmente produzem. Eles se definem a si mesmos como indústrias... (ADORNO; HORKHEIMER, 1973a, p. 114)

Nessa passagem ainda encontramos a expressão "cultura de massas" que, como se sabe, foi um dos motivos que levaram os autores a cunharem o conceito de Indústria Cultural: justamente denunciar que não há nenhuma "cultura das massas", como se as próprias massas tivessem um patrimônio cultural a ser preservado, desenvolvido e transmitido. A existência mesma das massas advém de uma privação de patrimônio cultural (e não só cultural); o que é chamado de "cultura de massas" é mais uma "cultura para as massas", feita "sob medida" para a adaptação social.

Claro que não é uma cultura imposta maquiavelicamente por uma classe dirigente. O advento da Indústria Cultural se situa como um dos desenvolvimentos da lógica irracional do Esclarecimento, lógica na qual a técnica assume cada vez mais o papel de legislador último das re- 
lações humanas. Por isso, uma "explicação tecnológica” geralmente é dada para o advento daquela, nos dizem os autores. O fato de os "bens culturais" serem produzidos por muitos e destinados a muitos mais ainda "imporia métodos de reprodução" e tornaria inevitável a disseminação de "bens padronizados para a satisfação de necessidades iguais" (ibid., grifo nosso). Ou seja, tanto a produção quanto a recepção dos bens culturais são vistas em função meramente da técnica.

Nas palavras de Jay (1988):

\begin{abstract}
Uma das principais queixas de Adorno contra a indústria cultural referia-se à sua deliberada função mistificadora. Nesse aspecto, a análise clássica de Marx acerca do fetichismo da mercadoria estava na base de sua argumentação, pois Adorno alegava que os produtos da indústria cultural não são obras de arte posteriormente transformadas em mercadoria; eles são, na realidade, produzidos desde o início como itens fungíveis a ser vendidos no mercado. (p. 110)
\end{abstract}

Com isso, porém, repetimos, ocorre uma inversão da própria concepção de cultura, como vinha sendo pensada até então. Não que a cultura antes da indústria cultural já não tivesse a marca da mercadoria. Na Dialética do Esclarecimento, Adorno e Horkheimer falam sobre como o caráter mercantil da obra de arte não é novo, mas sim ele se declarar deliberadamente como tal.

Mais uma vez, e não pela última, o mercado comparece como um condicionante, em nossa história, da possibilidade de liberdade: "as puras obras de arte, que negam o caráter mercantil da sociedade pelo simples fato de seguirem sua própria lei, sempre foram ao mesmo tempo mercadorias" (ADORNO; HORKHEIMER, 1973a, p. 147). Segundo eles, a liberdade da obra de arte, um objeto da cultura, foi conseguida graças à liberdade do mercado, e a arte como um domínio separado só foi possível na história como arte burguesa. Portanto, há um aspecto progressista no caráter mercantil da obra. Porém, dialético, esse caráter contém em si também um aspecto regressivo. Isso porque essa liberdade propiciada por ele se deu "em oposição à práxis material” e foi obtida ao preço “da exclusão das classes inferiores” (ibid., p. 127) - isto é, “documento de cultura, documento de barbárie". A arte séria exige tempo livre e dedicação que os trabalhadores explorados não possuem. Para estes a arte só pode assumir confortavelmente o lugar de um descanso, uma preparação para o trabalho. Por isso os autores afirmam que "a arte leve acompanhou a arte autônoma como uma sombra" e que ela é a "má consciência social da arte séria" (ibid., loc. cit.). Veremos, na parte Iv, como Adorno, na Teoria Estética, desenvolve essa contradição entre liberdade e dominação, produzida pelo caráter de mercadoria presente 
tanto na arte leve quanto na arte séria. E mais, veremos como um dos pilares da sua crítica às obras de arte é justamente a forma como estas expressam (ou nem expressam) essa contradição. Por enquanto, vamos nos ater à "cultura" de modo geral.

Até aqui falamos, direta ou indiretamente, de duas características regressivas que consideramos centrais na concepção de esclarecimento ${ }^{23}$ em Adorno (e Horkheimer): a absolutização e a dominação; presentes tanto no controle da natureza exterior quanto da humana. Outra característica do esclarecimento, porém, que a Indústria Cultural nos dá a oportunidade de explicitar (portanto, anterior a ela) é a repetição. No primeiro capítulo da Dialética do Esclarecimento, por exemplo, os autores nos dizem que um dos princípios do esclarecimento, que já era um princípio do próprio mito, é "a explicação de todo acontecimento como repetição" (ibid., p. 26). Ou ainda:

\footnotetext{
A subsunção do factual, seja sob a pré-história lendária, mítica, seja sob o formalismo matemático, o relacionamento simbólico do presente ao evento mítico no rito ou à categoria abstrata na ciência, faz com que o novo apareça como algo predeterminado, que é assim na verdade o antigo. (ibid., p. 39)
}

Nesse sentido, o fenômeno da Indústria Cultural, desenvolvimento moderno do esclarecimento (e suas contradições), também reduz a cultura à mera repetição, impede o surgimento do novo e, com isso, sua diferenciação (da cultura). Repetição que irá refletir, por exemplo, na formação dos indivíduos, parte da cultura. Mas fiquemos por aqui, por enquanto. No decorrer deste trabalho teremos diversas oportunidades de trazer novamente o tema, e desenvolvê-lo em outros pormenores.

23 Que, como já dissemos anteriormente, para nós, representa o movimento da cultura que pretendia se libertar do domínio da natureza, mas tem acarretado em violência sobre o homem - barbárie. 


\section{O Conceito de Emancipação}




\section{Emancipação e Aufklärung}

Tal como os conceitos de cultura, formação e arte, nos aproximaremos do conceito de emancipação pelos caminhos indicados por Adorno. Neste caso um texto incontornável, a nosso ver, é o breve ensaio de Kant publicado no jornal Berlinische Monatsschrift em 1783, intitulado Resposta à Pergunta: Que É "Esclarecimento"? (Aufklärung). ${ }^{24}$ Segundo Adorno:

\footnotetext{
Ali ele define a menoridade ou tutela e, deste modo, também a emancipação, afirmando que este estado de menoridade é auto-incupável quando sua causa não é a falta de entendimento, mas a falta de decisão e de coragem de servir-se do entendimento sem a orientação de outrem. "Esclarecimento é a saída dos homens de sua auto-incupável menoridade”. Este programa de Kant, que mesmo com a maior má vontade não pode ser acusado de falta de clareza, pareceme ainda hoje extraordinariamente atual. (ADORNO 2003b [1969], p. 169)
}

Portanto, em resumo, emancipação é a saída da menoridade auto-incupável, possível graças à Aufklärung.

Escolhemos, nesse momento, manter o termo em alemão, porque acreditamos que a tradução por Esclarecimento, ao invés de Iluminismo, apesar de ser muito bem justificada no caso da tradução da Dialética do Esclarecimento, adquiriu uma significação por demais separada do Iluminismo, enquanto movimento histórico-filosófico, que gostaríamos de retomar. Como aprendemos com Benjamin e Adorno, as palavras guardam a história (lembremos: “o

24 Ensaio publicado em uma seção deste jornal em que leitores ilustres podiam enviar cartas como resposta a perguntas levantadas (FOUCAULT, 2000 [1984], p. 335). 
tema alegórico é simplesmente história”); assim, a palavra Aufklärung, hoje, guarda a história do Iluminismo, ainda que seja anterior a ele e se diferencie dele.

Na Dialética do Esclarecimento, o termo, segundo o tradutor Guido de Almeida "não se pode resumir, para nossos autores [Adorno e Horkheimer], às Luzes do século dezoito. Não só a expressão não designa mais um movimento filosófico, mas resulta de um aprofundamento crítico que leva à desilusão de seu otimismo" (ADORNO; HORKHEIMER, 1985, p. 8). Concordamos plenamente, tanto que não optaríamos pela tradução por Iluminismo simplesmente.

Na mesma Nota Preliminar do Tradutor, Almeida fala sobre como o termo em alemão remete tanto a uma significação coloquial (sexuelle Aufklärung e politische Aufklärung: esclarecimento sexual e político, respectivamente) quanto filosófica, quando, a propósito, lembra a vinculação do termo ao texto mencionado de Kant:

\footnotetext{
Kant, como se sabe, define a Aufklärung, num texto célebre, como um processo de emancipação intelectual resultando, de um lado, da superação da ignorância e da preguiça de pensar por conta própria e, de outro lado, da crítica das prevenções inculcadas nos intelectualmente menores por seus maiores (superiores hierárquicos, padres, governantes, etc.). (ibid., p. 7)
}

O fato do termo Aufklärung ter assumido cada vez mais para Adorno, e para os outros autores da Teoria Crítica, um sentido que justifica sua tradução em português por Esclarecimento e não por Iluminismo, não significa que essa tradução se justifique sempre e em todos os casos. O termo Aufklärung guarda uma história que não pode ser desconsiderada, para nossos objetivos, e, devido a sua centralidade, sua tradução exige essa consideração histórica. Como diz Benjamin:

\footnotetext{
A tradução é a transposição de uma língua para outra por meio de um "continuum" de conversões. A tradução passa por um contínuo de conversão, e não por domínios abstractos de igualdades ou semelhanças. ${ }^{25}$ (BENJAMIN, 1992b, p. 189)
}

Isto é, não dá para simplesmente estabelecer de uma vez por todas equivalentes abstratos entre duas línguas, esse contínuo de conversões é necessário justamente porque ele é permeável à história.

25 Vale acrescentar o contraponto dialético de que a abstração também cumpre um papel importante na tradução, de transcendência do particular da língua. 
Pode parecer que nos detemos em demasia em algo que pode ser considerado por alguns como mero detalhe. Mas uma das coisas que pretendemos que fique clara ao longo deste trabalho é que a obra de autores como Adorno e Benjamin contém um esforço gigantesco justamente para que a linguagem, expressão do mundo (nela, e não através dela, no sentido limitador da palavra "através", como vimos), deixe de valer somente pelo caráter intercambiável da mercadoria que ela adquiriu no mundo moderno, com o exagero de sua função de abstração, e passe a valer também pelo que ela contém de particular e único (em certo sentido "aurático"), como na obra de arte autêntica; ainda que a obra de arte muito deva à mercadoria, e que seu caráter único não tenha se realizado ainda senão como utopia. Mas não nos adiantemos tanto.

É importante entender Aufklärung também como Iluminismo aqui porque queremos chamar a atenção para o contexto em que essa preocupação (com a saída da menoridade) de Kant pôde tomar a forma que vimos acima. Não podemos esquecer que a data de publicação de Resposta à Pergunta: Que É Aufklärung? é 1783, portanto apenas 6 anos antes da data marco da Revolução Francesa, em 1789, mas já sob a influência profunda de seus ideais, advindos do Iluminismo francês.

A Alemanha, porém, obviamente não era a França, e diferenças muito marcantes como o grau de urbanização e o desenvolvimento da burguesia, por exemplo, não poderiam produzir uma filosofia com o mesmo tom. Vejamos o que Eagleton (1993) nos diz sobre a Alemanha dessa época, terminando mesmo por situar Kant, numa citação extensa, mas que nos será muito útil em mais de uma ocasião (não apenas agora, a propósito de Kant, mas também a propósito de Schiller e Goethe), pela sua descrição ampla e ao mesmo tempo sintética:

\footnotetext{
A Alemanha desse período [século XVIII] era um território parcelado de estados feudais absolutistas, marcados por particularismos e idiossincrasias em função da ausência de uma cultura comum. Seus príncipes impunham seus diktats imperiais através de intrincadas burocracias, enquanto um campesinato omniosamente explorado era mantido, freqüentemente, em condições próximas às das bestas. Abaixo deste controle autocrático, uma burguesia ineficaz era imobilizada pela política mercantilista da nobreza, com a indústria controlada pelo estado e o comércio pelos impostos, submetida ao poder generalizado dos tribunais, alienada das massas degradadas, e excluída de qualquer influência corporativa na vida nacional. Os Junker, confiscando à classe média o seu papel histórico, patrocinavam, eles mesmos, o que havia de desenvolvimento industrial para os seus próprios propósitos fiscais ou militares. Deixando a classe média, em larga escala, passiva, fazendo seus negócios com o estado, em lugar de forçar o estado a promover políticas dirigidas aos seus interesses. Uma generalizada falta de capitais e de iniciativa, comunicações precárias, o comércio organizado
} 
localmente, e vilas dominadas por guildas, abandonadas no interior atrasado: eram essas as condições pouco favoráveis da burguesia, nesta ordem social paroquial e opressiva. Os seus estratos profissionais e intelectuais, no entanto, cresciam rapidamente, produzindo, pela primeira vez, no final do século XVIII, uma casta literária profissional; e este grupo mostrava todos os sinais de exercer uma liderança cultural e espiritual para além do interesse da aristocracia. Sem bases no poder político ou econômico, no entanto, esse esclarecimento burguês mantinha-se em muitos respeitos hipotecado ao absolutismo feudal, marcado por um profundo respeito à autoridade. $\mathrm{O}$ caso de Immanuel Kant, corajoso Aufklärer e súdito dócil do rei da Prússia, pode ser tomado como exemplar. (p. 18)

Nesse sentido, Kant, no texto citado anteriormente, por exemplo, diz que a época em que vivia não era uma época esclarecida, mas de esclarecimento, e a chamou também de "Século de Frederico", em homenagem ao rei. Mas vejamos ainda o que o autor nos diz mais especificamente sobre Kant:

\begin{abstract}
A sociedade política onde Kant viveu não era, de nenhum modo, uma sociedade burguesa completamente desenvolvida, e, assim, falar dele como um filósofo burguês pode parecer a alguns algo de anacrônico. $\mathrm{O}$ seu pensamento, no entanto, alimenta por muitos caminhos os ideais do liberalismo da classe média, e é utópico, nesse sentido enriquecido e positivo. Do coração da autocracia, Kant defende valores que se mostrarão, em última instância, subversivos daquele regime; mas seria muito parcial vê-lo só por esse lado, como um campeador liberal, e não perceber como seu pensamento já está desvelando alguns dos problemas e contradições da ordem emergente da classe média. (ibid., pp. 59-60)
\end{abstract}

O que nos interessa destacar nesse momento do que foi trazido acima é que o Iluminismo de Kant continha ideais libertadores subversivos para o estado político vigente, mas não colocava a revolução política como "saída", como pôde acontecer na França, e sim, como veremos, a transformação subjetiva. Foucault (200o) sobre o texto publicado no Berlinische Monatsschrift diz:

Desde o primeiro parágrafo, [Kant] enfatiza que o próprio homem é responsável por seu estado de menoridade. É preciso conceber então que ele não poderá sair dele a não ser por uma mudança que ele próprio operará em si mesmo. (p. 338)

Em Educação após Auschwitz (2003b) encontramos novamente a referência de Adorno a Kant, enfatizando a autodeterminação:

O único poder efetivo contra o princípio de Auschwitz seria autonomia, para usar a expressão kantiana. O poder para a reflexão, a autodeterminação, a não-participação. (p. 125) 
Entretanto, importante notar que esse recurso a Kant, e à autodeterminação, por parte de Adorno, também advém a partir de um diagnóstico de modernidade em que as mudanças políticas e econômicas não parecem possíveis:

\begin{abstract}
Como hoje em dia é extremamente limitada a possibilidade de mudar os pressupostos objetivos, isto é, sociais e políticos que geram tais acontecimentos, as tentativas de se contrapor à repetição de Auschwitz são impelidas necessariamente para o lado subjetivo. (ibid., p. 121)
\end{abstract}

Isso não significa um psicologismo, nem em Kant, nem em Adorno, isto é, um abandono da esfera política em favor da meramente individual. Kant (2009 [1783]) fala que a forma de favorecer o esclarecimento é o "uso público da razão":

\begin{abstract}
Entendo contudo sob o nome de uso público de sua própria razão aquele que qualquer homem, enquanto sábio, faz dela diante do grande público do mundo letrado. Denomino uso privado aquele que o sábio pode fazer de sua razão em um certo cargo público ou função a ele confiado. (p. 66)
\end{abstract}

Isto é, o homem esclarecido, que procura sair da menoridade, só pode fazer isso ao se colocar em relação com outros homens, num espaço público, e o uso privado seria um abuso do poder confiado a um indivíduo num cargo determinado. Foucault (200o) argumenta justamente no sentido de mostrar como no texto de Kant o problema, colocado nesses termos, é um problema político. Segundo ele, Kant faz "uma espécie de contrato" com Frederico II, daquilo que pode ser chamado de despotismo esclarecido:

\footnotetext{
O uso público e livre da razão autônoma será a melhor garantia da obediência, desde que, no entanto, o próprio princípio político ao qual é preciso obedecer esteja de acordo com a razão universal. (p. 340)
}

Nos termos de Kant, quando o esclarecimento define "os princípios do governo", é conveniente "tratar o homem, que agora é mais do que simples máquina, de acordo com a sua dignidade" (KANT, 2009, p. 71).

Importante salientar, a nosso ver, porém, que a aposta de Kant e Adorno na mudança subjetiva, frente à impossibilidade da mudança política e econômica efetiva, vem do pressuposto de que uma mudança política sem uma mudança subjetiva apenas iria perpetuar a situação anterior sob uma nova máscara, e não devido a uma falta de atitude prática: 
Uma revolução poderá talvez realizar a queda do despotismo pessoal ou da opressão ávida de lucros ou de domínios, porém nunca produzirá a verdadeira reforma do modo de pensar. Apenas novos preconceitos, assim como os velhos, servirão como cintas para conduzir a grande massa destituída de pensamento (ibid., p. 65)

Em Teoria da Semiformação ${ }^{26}$ (1996 [1966]), de Adorno, encontramos algo semelhante:

O fracasso dos movimentos revolucionários, que queriam realizar nos países ocidentais o conceito de cultura como liberdade, provocou uma certa retração das idéias de tais movimentos, e não somente obscureceu a conexão entre elas e sua realização, mas também as revestiu de um certo tabu. (p. 389)

Ou ainda na Dialética do Esclarecimento, a respeito da revolução nos termos do socialismo:

Reconhecer, porém, a presença da dominação dentro do próprio pensamento como natureza não reconciliada seria um meio de afrouxar essa necessidade que o próprio socialismo veio a confirmar precipitadamente como algo de eterno, fazendo assim uma concessão ao common sense reacionário [...] Mas uma verdadeira práxis revolucionária depende da intransigência da teoria em face da inconsciência com que a sociedade deixa que o pensamento se enrijeça. (ADORNO; HORKHEIMER, 1985, p. 51)

Isto é, assim como na época de Kant, este já temia que uma revolução apenas política poderia manter os homens na menoridade, como por fim se mostrou a Revolução Francesa, quando os ideais do Iluminismo que sustentaram ideologicamente o movimento não foram realizados sob o governo instaurado (pelo contrário, o que se realizou foi a barbárie), para Adorno (e Horkheimer) qualquer revolução, mesmo que sob os ideais iluministas do socialismo, tem que partir de uma mudança do próprio pensamento.

Essa relação entre emancipação e Aufklärung é de extrema importância para nós porque ela justifica o caminho tomado por Adorno em prol da formação, para a qual dedicaremos a próxima parte. Nela veremos em quais termos a formação é uma saída possível da menoridade (e do julgo da natureza) sem recair em barbárie (dentro do possível, em uma sociedade bárbara), e qual é o papel essencial da estética nessa, partindo de Schiller, que se dedicou especificamente ao problema da formação. Veremos brevemente, como Schiller, por sua vez, partiu

26 Na parte seguinte deste trabalho, comentamos nossa opção de tradução, tendo em vista nossos objetivos, de Theorie der Halbbildung por Teoria da Semiformação e não por Teoria da Semicultura, apesar do texto consultado optar pela segunda. 
do pensamento de Kant (e dos problemas deixados por este), e a importância da sua relação com Goethe, o qual, em um período de intensa comunicação com o primeiro, lança um romance que funda o conceito moderno de formação (Bildung); e depois veremos, a partir dessa que chamaremos concepção clássica de formação, como Adorno se colocou diante do problema.

Vejamos, antes disso, dois outros tópicos relacionados à emancipação, em Adorno, que acreditamos serem importantes ter em mente quando se investiga esse conceito neste autor: o modelo da mônada e a relação entre teoria e práxis.

\section{O Modelo da Mônada}

O modelo da mônada leibniziana é muitas vezes utilizado por Adorno para explicar relações de independência, sempre relativa, quer do indivíduo quer da arte frente à sociedade. Como quase tudo em Adorno, porém, o modelo da mônada tem um antecedente em Benjamin.

Na Origem do Drama Trágico Alemão, no qual Adorno se baseou, como vimos, para seu conceito de história natural, encontramos também uma referência de Benjamin a tal modelo. No Prólogo Epistemológico-Crítico dessa obra, comentando justamente a idéia de história natural ser um devir, ilimitado, e não como uma essência, limitada; ele diz que a tendência da formação de todos os conceitos filosóficos é constatar esse devir, "absorver toda a história de um fenômeno". Com isso abre-se uma porta possível para se abarcar a totalidade sem fetichizá-la, já que a história do fenômeno "não conhece, em princípio, limites, quer no que se refere ao passado, quer ao futuro"; o conceito, mesmo tratando do devir, do ilimitado, fala do todo, em sua limitação. Nesse momento ele insere o modelo da mônada: "A sua estrutura [do conceito], marcada pela totalidade, em contraste com o seu inalienável isolamento, é monadológica. A idéia é uma mônada" (BENJAMIN, 2004, p. 34).

$\mathrm{Na}$ introdução a uma edição da coleção Os Pensadores, no volume dedicado a Leibniz, sob consultoria de Marilena Chauí, encontramos um resumo da noção de mônada para esse autor. Grosso modo, Leibniz tinha uma concepção de mundo dinâmica, oposta à de Descartes - geométrica e mecânica dos corpos. Para ele os corpos não se revelam como extensão, tal qual para Descartes, mas como forças. O universo seria composto, então, por unidades de 
força, as mônadas. Estas "não teriam portas nem janelas”, não se comunicariam com o mundo, mas seriam elas mesmas representações do universo, em diferentes graus de perfeição, e teriam diferentes graus de consciência da totalidade que expressam (LEIBNIZ, 2004, pp. 9-11).

Quando Benjamin diz que a idéia é uma mônada ele quer apontar justamente para esse caráter de independência relativa da idéia frente ao mundo. Ela pode ser, de certo modo, “isolada", uma unidade, mas "cada idéia contém a imagem do mundo", isto é, cada uma delas expressa em sua particularidade a totalidade; é uma “interpretação objetiva do mundo". Não é casual que Leibniz, nos diz Benjamin, também tenha sido o criador do cálculo infinitesimal, ${ }^{27}$ uma forma de abarcar o infinito de forma finita.

Porém, Benjamin não desenvolve essa concepção além disso e não elucida problemas que podem surgir a partir de sua leitura, como por exemplo, o levantado por Günter Figal ${ }^{28}$ (apud DUARTE, 1993, p. 124), a respeito da obscuridade dessa concepção, ao não deixar claro, segundo ele, como se faz a mediação entre a idéia e o mundo, entre o particular e o universal. Segundo este autor, esse seria um caso em que se aplicaria o ponto central da divergência entre Adorno e Benjamin, sobre a qual trataremos melhor em outro momento. Por enquanto, nos basta apontar que Adorno, ao aplicar o modelo da mônada ao indivíduo e à obra de arte põe em evidência, a nosso ver, a base material que ficou obscura em Benjamin, para estruturar essa mediação.

No verbete Indivíduo, de Temas Básicos da Sociologia (1973b), Adorno e Horkheimer citam diversas passagens de Leibniz para afirmar que sua "teoria das mônades oferece um modelo conceptual para a visão individualista do homem concreto na sociedade burguesa" (p. 46); mas criticam a absolutização desse modelo, quando as mônadas são consideradas como "ser em si”, justamente porque, desse modo, se esquece da mediação da sociedade. Caberia então, segundo eles, à Filosofia especulativa e à Sociologia mostrarem essa mediação.

Em Sobre o Caráter Afirmativo da Cultura (1997), do mesmo modo Marcuse faz referência ao modelo da mônada, também para reforçar o caráter individualista da sociedade burguesa, mas então em contraposição, principalmente, à solidariedade:

27 Simultaneamente a Newton, como nos lembra a introdução do volume de Os Pensadores, citada há pouco.

28 FIGAL, G. Das Naturschöne als spekulative Gedankenfigur. Zur Interpretation der Ästhetischen Theorie Adornos. Bonn: Bouvier Verlag, 1977. p. 8 o. 
O indivíduo é considerado uma mônada independente e auto-suficiente. Sua relação com o mundo (humano e extra-humano) é, ou abstrata e imediata - o indivíduo constitui o mundo já em si mesmo (como um eu dotado de conhecimento, sentidos e vontade) - ou abstrata e mediata - é determinada pelas leis cegas da produção de mercadorias e do mercado. Em ambos os casos o isolamento do indivíduo enquanto mônada não seria superado. Sua superação representaria a produção de uma solidariedade efetiva [...] (p. 110)

Em Adorno, porém, o caráter dialético desse modelo fica mais evidente, a nosso ver. Analisemos brevemente o aforisma da Minima Moralia (1992) que traz justamente esse nome Mônada - e vejamos como a própria "cristalização" monadológica do indivíduo na sociedade burguesa tem sua parcela na possibilidade de liberdade. Logo de início encontramos:

O indivíduo deve sua cristalização às formas da economia política, em particular ao mercado urbano. Mesmo como oponente das pressões da socialização, ele permanece sendo seu produto mais característico e a ela semelhante. O que lhe permite a resistência, cada traço de independência, tem sua fonte no interesse individual monadológico e na cristalização desse como caráter. O indivíduo reflete, precisamente em sua individuação, a lei social preestabelecida da exploração, por mais que esta seja mediatizada. (pp. 130-131)

Novamente, Adorno dá “nomes aos bois”. De modo similar ao que vimos no início da parte anterior, a independência da cultura, aqui representada por essa figura do indivíduo autônomo, só foi possível graças à economia de mercado. Sua independência relativa foi prevista pela lei social da exploração. Essa é a dialética da emancipação: ao mesmo tempo destacada e baseada, historicamente, na exploração.

Interessante notar também que nesse aforismo, o exemplo que Adorno dá (e os exemplos, como vimos, nunca são mera ilustração) é o da arte, em especial, a música. Ele diz:

A música de Beethoven, cujo cenário são as formas socialmente transmitidas e que, ascética em relação à expressão de sentimentos privados, ressoa como o eco orientado num sentido bem determinado das lutas sociais, extrai precisamente dessa ascese toda a plenitude e força do individual. A de Richard Strauss, inteiramente a serviço das exigências individuais e dirigida para a glorificação do indivíduo auto-suficiente, rebaixa por isso mesmo este último a um mero órgão de recepção do mercado, a um imitador de idéias e estilos descompromissadamente escolhidos. No interior da sociedade repressiva, a emancipação do indivíduo não o beneficia apenas, mas também o prejudica. A liberdade em face da sociedade priva-o de força para a liberdade. (ibid., pp. 131-132)

Note que a música de Beethoven, orientada socialmente e "ascética à expressão de sentimentos privados", tem mais força individual que a de Strauss, pretensamente "mais" indivi- 
dual, auto-suficiente, mas que, por outro lado, ao se pretender mais livre do que pode ser, acaba, sem o saber, ainda mais refém das leis do mercado. Trocando em miúdos, para Adorno, quando a emancipação esquece a que está condicionada ela paga como preço a perda da liberdade.

Deixaremos para tratar da aplicação desse modelo também à obra de arte na parte dedicada ao conceito de arte, quando então teremos mais elementos para entender seu alcance.

\section{Teoria e Práxis}

Diversos críticos consideram os posicionamentos de Adorno como distantes da práxis, sendo isso uma das suas limitações. Bronner (1994), por exemplo, apesar de chamar Adorno de "talvez" o mais "deslumbrante", "instigante" e "complexo" representante da Teoria Crítica, diz que ele foi incapaz de tirar conclusões práticas, e que com isso sua dialética teria se imobilizado.

Segundo ele, Adorno e Horkheimer rejeitam "toda tentativa de dar conteúdo à ilusão mais radical" e adotaram o Bilderverbot, "a injunção judaica contra a tentativa de retratar Deus" (p. 230), estendendo-o à utopia: "Romper a relação entre a teoria e a prática e identificar a autonomia com uma e a repressão com a outra define o novo ramo de teoria crítica associado a Adorno" (p. 240).

Essa, contudo, não é a nossa posição, e no texto do próprio Bronner encontramos elementos em contrário.

Segundo ele, desde a entrada de Adorno no Instituto de Pesquisa Social, havia já nele um ímpeto negativo que acreditava não ser possível sustentar, nessa sociedade, qualquer compromisso genuíno com a felicidade. E que a dialética negativa apresentada em sua obra de maturidade sempre foi um confronto com as "condições falsas" das coisas. Para Adorno, diz Bronner, "a realidade é um constante ataque contra a liberdade" e "a liberdade perdida no processo de reificação só pode ser reafirmada como ilusão" (p. 224).

Concordamos com Bronner quando ele diz que para Adorno a liberdade só pode ser reafirmada como ilusão, se pensarmos ilusão não só em seu sentido depreciativo, mas também no sentido de imagem utópica. Porém não podemos concordar de forma alguma com a afirmação de que este se nega a dar um "conteúdo" a ela. O próprio Bronner diz: 
Isso [a liberdade reafirmada como ilusão] exige uma linguagem diferente, capaz de afirmar sua qualidade "sensual" ao sujeito, e irredutível a qualquer categoria filosófica ou a qualquer conjunto de condições objetivas. Não é de estranhar, portanto, que para Adorno a linguagem "mimética" das obras de arte expressasse de maneira mais direta aquilo que, nos termos de uma realidade reificada, é a ilusão da liberdade (p. 224)

Ora, talvez não seja mesmo possível dar um conteúdo à ilusão nos termos da linguagem reificada. Mas não há no trecho citado um indicativo dessa outra linguagem na qual possamos encontrar um conteúdo? O próprio Bronner diz em outro momento:

\begin{abstract}
A negação estética sugere assim uma positividade que, nos termos de uma realidade reificada, permanece sempre negativa. É nesse sentido que as últimas obras de Adorno realizam o desejo anterior de oferecer um "conceito positivo de Iluminismo". (p. 232)
\end{abstract}

Bronner parece estar preocupado em encontrar prescrições sistemáticas para práticas políticas, o que certamente não encontraria em Adorno. Mas dizer que seu posicionamento é uma espécie de subjetivismo ${ }^{29}$ talvez seja não depreender de sua obra seu potencial mais original. Eagleton (1993), por exemplo, corrobora a idéia de certa deficiência no posicionamento político declarado de Adorno. Mas enxerga em sua obra uma base para a política que ele não encontra em seus antecessores ou sucessores.

Pode-se ver claramente essa posição numa diferenciação que ele faz entre Lukács e Adorno no que tange ao conceito de totalidade:

Para Lukács, a totalidade já existe, em princípio, mas ainda tem que chegar a si mesma. O realismo literário prefigura esse dia glorioso, recriando cada fenômeno à imagem da essência que ele traz na barriga. Para Adorno, as coisas são bem o oposto: há, sem dúvida, aqui e agora, um sistema total que integra tudo impiedosamente até o fim, mas para emancipar a não-identidade de suas garras vorazes se deveria buscar transformar essa situação miserável numa “constelação" histórica futura, na qual a identidade racional seria constituída por aquele hiato no interior de cada particular que o abre à alteridade incontrolável

"Adorno identifica a liberdade à subjetividade, mais do que a um ordenamento sociopolítico capaz de fazer exigências recíprocas a seus membros com base em uma interpretação liberal do domínio da lei. A liberdade contenta-se agora em contestar o poder e esquece assim que este é necessário para restringir seu exercício arbitrário. Perde-se a função ética e prática da liberdade, e esta se torna transcendente e deixa de ter sua ligação imanente com os assuntos humanos" (ibid., p. 240). 
de seus próximos. Essa ordem política seria tão distante de um regime "totalitário" quanto de uma distribuição casual de mônadas ou um fluxo de pura diferença; e nesse sentido há uma base para a política na obra de Adorno, que parece bastante duvidosa na de alguns de seus sucessores teóricos. (p. 258)

Assim, o que para Bronner parece ser um subjetivismo político em Adorno, para Eagleton se configura numa outra ordem de política que ainda não é possível justamente porque na atual falta a subjetividade necessária.

Eagleton fala que "talvez" haja dois Adornos, "um, de certo modo, mais derrotista do que o outro". Em um deles a estética seria seu esconderijo, numa fuga ao pesadelo da história. Mas há também outro, "que ainda tem esperança de que atravessemos a estética e saiamos do outro lado, num lugar inomeável; o teórico para quem a estética oferece um paradigma, mais que um simples deslocamento do pensamento político emancipador” (p. 261).

Outro comentador, Duarte (1993), não faz essa divisão:

A arte não é para Adorno, certamente, um repasto espiritual que tornaria melhores os dias no Grande Hotel Abismo, que antecedem o juízo final, mas de modo extremamente veraz, o lugar-tenente da possibilidade de uma práxis melhor. (p. 118, grifo nosso)

À parte da existência de dois Adornos ou não, tanto Eagleton (1993) quanto Duarte (1993) desenvolvem a idéia de que a contribuição de Adorno para a práxis se encontra no paradigma de racionalidade que a arte oferece, como veremos em maior detalhe na quarta parte. Para dizer ainda um pouco mais a respeito da relação entre teoria e práxis - agora recorrendo ao próprio Adorno - pode-se notar logo no prefácio da Dialética do Esclarecimento (1985), escrita em conjunto com Horkheimer, um alerta que os autores nos fazem para parar por um instante antes de tomar qualquer decisão tradicionalmente considerada como prática, seja ela política, científica ou pedagógica:

É característico de uma situação sem saída que até mesmo o mais honesto dos reformadores, ao usar uma linguagem desgastada para recomendar a inovação, adota também o aparelho categorial inculcado e a má filosofia que se esconde por trás dele, e assim reforça o poder da ordem existente que ele gostaria de romper. (p. 14)

Já nesse primeiro momento fica evidente a concepção de teoria e prática que, a nosso ver, Adorno não abandonará até seus últimos escritos. Para ele, não pode haver verdadeira 
prática que não contenha em si a reflexão, senão é prática "fechada", "práxis ilusória" (ADORNO, 1995b [1969], p. 202). Ao mesmo tempo o próprio pensamento, para ele, é práxis: “pensar é um agir, teoria é uma forma de práxis" (ibid., p. 204).

Durante toda a entrevista concedida a revista Der Spiegel, no ano de sua morte, Adorno é questionado por sua posição política, a qual a revista faz parecer como distante da prática. Adorno, nesse momento também, insiste em sua posição. A entrevista termina da seguinte maneira:

\footnotetext{
Spiegel: O senhor continua a ver, portanto, como a forma mais significativa e necessária da sua atividade na República Federal Alemã fazer progredir a análise das condições da sociedade?

Adorno: Sim, e mergulhar em fenômenos singulares muito determinados.

Não me envergonho de tornar público que estou trabalhando em um grande livro de estética. (ADORNO, 2003h, p. 137)
}

Esse livro mencionado por Adorno é o próprio Teoria Estética, do qual analisaremos algumas partes, e que, infelizmente, não chegou a ser publicado em vida.

Assim, podemos dizer que o pensamento de Adorno é tanto uma crítica à práxis dominante quanto ele próprio uma práxis. Toda a sua obra é um exercício dela, e por isso é tão importante compreender esse ponto, se nos propomos a nos aproximar desse autor.

Quando ele e Horkheimer nos dizem, ainda do prefácio da Dialética do Esclarecimento, que o "cerceamento da imaginação teórica preparou o caminho para o desvario polítiCO" (ADORNO; HORKHEIMER, 1985, p. 12), estão preocupados eminentemente com o destino da humanidade, não menos em xeque em face à Segunda Guerra que agora. Seus escritos não são letra morta, pelo contrário, são uma investida heróica na tentativa de reinvestir vida às palavras.

Por esse motivo o próprio pensamento é o "primeiro objeto" a ser investigado. Para não se cair no erro de "recomendar uma inovação com uma linguagem desgastada", para que nossas ações não sejam, sem que saibamos, o contrário do que pretendíamos com elas.

"Não alimentamos dúvida nenhuma", os autores nos dizem, "de que a liberdade na sociedade é inseparável do pensamento esclarecedor" (ibid., p. 12). Contudo, eles continuam, esse mesmo pensamento, quer em seu conceito, quer em suas "formas históricas concretas", as instituições, tem conduzido a sociedade ao contrário da liberdade objetivada: "Se o esclareci- 
mento não acolhe dentro de si a reflexão sobre esse elemento regressivo, ele está selando seu próprio destino" (ibid., p. 12).

Assim, de nossa parte, acreditamos não só que a obra de Adorno traz uma base para a política, como afirma Eagleton (1993), como é ela própria política. Se manter na teoria não é uma "deficiência no posicionamento político declarado", mas um posicionamento político declarado e firme de resistência: pensar numa sociedade que coage a não pensar. Fazer política não é só aderir a partidos e seus programas. Numa sociedade em que o cerne de suas instituições funcionam com uma "racionalidade irracional" aderir a qualquer uma delas incondicionalmente, mesmo a mais progressista, já é coadunar com a irracionalidade.

Além do mais, Adorno não se furtava a manifestações pontuais acerca de acontecimentos ou decisões políticas nem a teorizar diretamente (e não apenas indiretamente, sob a máscara da estética) a democracia.

No primeiro caso, por exemplo, podemos citar a manifestação de Adorno a respeito do perigo totalitário das "leis de emergência" na República Federal da Alemanha (ADORnO, 2003h); não por acaso publicada no Brasil ${ }^{30}$ juntamente com a entrevista acima citada de Adorno para Der Spiegel. A intenção do tradutor, Gabriel Cohn, como ele diz em nota, era justamente mostrar como "esse intelectual supostamente alheio às questões palpáveis do dia-a-dia, na realidade não se furtava a manifestar-se em público”.

No segundo caso, para dar também um exemplo, escolhemos um trecho da $\mathrm{Mi}$ nima Moralia em que Adorno fala sobre uma "sociedade emancipada", e podemos encontrar uma concepção explícita de democracia muito próxima, a nosso ver, daquilo que Eagleton (1993) viu como uma base para a política (diretamente, portanto, o que este considera apenas indiretamente):

Que todos os homens sejam iguais uns aos outros, é precisamente o que viria a calhar para a sociedade. Ela considera as diferenças reais ou imaginárias como marcas ignominiosas, que atestam que não se avançou o bastante, que algo escapou da máquina e não está inteiramente determinado pela totalidade [...] Entretanto, uma sociedade emancipada não seria nenhum Estado unitário, mas a realização efetiva do universal na reconciliação das diferenças. A política que ainda estiver seriamente interessada em tal sociedade não deveria propagar a igualdade abstrata das pessoas sequer como uma idéia. Em vez disso, ela deveria a apontar 
para a má igualdade hoje, para a identidade entre os interessados no cinema e os interessados em armamentos, pensando, contudo, a situação melhor como aquela na qual é possível ser diferente sem ter medo. Quando se assegura ao negro que ele é exatamente como o branco, quando na verdade não o é, mais uma vez está se fazendo secretamente uma injustiça a ele. Humilham-no, assim, amistosamente com um padrão que vai necessariamente, sob a pressão dos sistemas, colocá-lo numa posição de inferioridade e que, ademais, seria um mérito duvidoso satisfazer. De resto, os partidários da tolerância unitária estão sempre inclinados à intolerância em relação a todo grupo que não se enquadra: o entusiasmo obtuso pelos negros é compatível com a indignação com a falta de modos dos judeus. A idéia de vir-se a cair nele evoca o martírio, não a democracia. (ADORNO, pp. 89-90, grifo nosso)

Quanto do que é feito em política ainda hoje não parte de uma igualdade abstrata entre as pessoas? Quantas vezes os "direitos iguais” não são invocados apenas para impedir qualquer reparação de injustiças históricas? A concepção de democracia, em Adorno, como pudemos ver, portanto, envolve uma igualdade que não apaga as diferenças, nem apaga o passado. Não iremos além disso, por enquanto. Mas, mantenhamos em mente esse trecho: "a sociedade emancipada" como "a realização efetiva do universal na reconciliação das diferenças" que, no decorrer deste trabalho, com os desenvolvimentos dos conceitos de formação e arte, poderemos voltar a esse tema de forma mais rica. 


\section{O Conceito de Formação}




\section{Formação enquanto Bildung}

Nem seria preciso dizer que o conceito de formação em Adorno também não é um fetiche, mas “diferente de época para época por seu conteúdo e suas instituições, e não se dispõe a transferências" (ADORNO, 1996, p. 391). Por isso, para compreender o conceito de formação em Adorno é necessário entendê-lo historicamente e, em primeiro lugar, em seu diálogo com o que ele chama de idéia clássica de formação.

Essa idéia, que o autor identifica em sua Teoria da Semiformação (1996) com "a filosofia de Schiller, dos kantianos e dos seus críticos”, envolvia, segundo ele, tanto um desenvolvimento das potencialidades dos homens na sua vida em sociedade por meio da domesticação do que há de animal na humanidade quanto a evitação da possibilidade de que uma dessas potencialidades fosse a destruição da natureza e do próprio homem, também parte dela. Portanto, a formação seria um desenvolvimento da cultura que não é mais simplesmente natureza, mas também não é violência contra a natureza; é algo entre a natureza e a barbárie:

\footnotetext{
E a idéia filosófica de formação que a ela corresponderia se dispôs a formar de maneira protetora a existência. Havia um duplo propósito: obter a domesticação do animal homem mediante sua adaptação inter-pares e resguardar o que lhe vinha da natureza, que se submete à pressão da decrépita ordem criada pelo homem. (p. 390)
}

Assim, essa idéia clássica mantinha a tensão entre espírito (liberdade) e natureza (necessidade). Quando essa tensão é desfeita, com a hipostasiação do espírito, de um lado, e 
o predomínio da adaptação do homem, de outro, esquecendo-se de que homem e espírito são também parte da natureza, esta cobra seu preço voltando a triunfar sob a forma de dominação.

\begin{abstract}
Quando o campo de forças a que chamamos formação se congela em categorias fixas - sejam elas do espírito ou da natureza, de transcendência ou de acomodação - cada uma delas, isolada, se coloca em contradição com seu sentido, fortalece a ideologia e promove uma formação regressiva. (loc. cit.)
\end{abstract}

Retomemos, por ora, o conceito de formação em Schiller (e Goethe), para que depois possamos entendê-lo melhor em Adorno. Antes disso, porém, a palavra em alemão por nós traduzida por formação, Bildung, merece, assim como mereceu Aufklärung, uma consideração especial. Suarez (2005) faz um pequeno estudo sobre o conceito de Bildung a partir de um artigo de Antoine Berman, Bildung et Bildungsroman. ${ }^{31}$ Para nossos objetivos aqui interessa, sobretudo, o seguinte trecho que ele destaca desse artigo:

\begin{abstract}
A palavra alemã Bildung significa, genericamente, 'cultura' e pode ser considerado o duplo germânico da palavra Kultur, de origem latina. Porém, Bildung remete a vários outros registros, em virtude, antes de tudo, de seu riquíssimo campo semântico: Bild, imagem, Einbildungskraft, imaginação, Ausbildung, desenvolvimento, Bildsamkeit, flexibilidade ou plasticidade, Vorbild, modelo, Nachbild, cópia, e Urbild, arquétipo. Utilizamos Bildung para falar no grau de "formação" de um indivíduo, um povo, uma língua, uma arte: e é a partir do horizonte da arte que se determina, no mais das vezes, Bildung. Sobretudo, a palavra alemã tem uma forte conotação pedagógica e designa a formação como processo. Por exemplo, os anos de juventude de Wilhelm Meister, no romance de Goethe, são seus Lehrjahre, seus anos de aprendizado, onde ele aprende somente uma coisa, sem dúvida decisiva: aprende a formar-se (sich bilden). (BERMAN apud SUAREZ, 2005, p. 193)
\end{abstract}

Segundo Bolle (1997), que também apresenta um breve e rico trabalho sobre o tema, o conceito moderno de Bildung surgiu na Alemanha no final do século xviII. Antes disso ela teria um emprego ligado ao sentido de "imagem" (Bild), geralmente usada para designar a formação de minerais, vegetais e animais na natureza, assim como, por outro lado, a atividade reprodutiva dos artistas. Sua migração semântica teria ocorrido somente com a Aufklärung. Vejamos como a explicação de Bolle e sua descrição da Alemanha da época nos coloca no mesmo contexto trazido anteriormente a propósito da Aufklärung:

31 Berman, A. Bildung et Bildungsroman. Le temps de la réflexion, v. 4. Paris, 1984. p. 142. 
Durante algum tempo, a Aufklärung usou as palavras Bildung e Erziehung [educação] simultaneamente, com predomínio da segunda, em que pesou a influência de Rousseau e de sua obra programática Émile ou De l'éducation (1762). Manifestou-se ali a tendência dos Aufklärer no sentido de uma "vontade de educar”. Significativamente, seus esforços culminaram na fórmula do "imperativo categórico" de Kant. Secularização de mandamentos divinos. Na Alemanha da época, surgiu a figura híbrida do pensador semi-religioso e semi-racionalista, semi-obediente e semi-rebelde. Como pano de fundo, tinhase Estados pequenos e médios, regidos pela fórmula do absolutismo tardio ou "despotismo esclarecido". As autoridades aristocráticas, que continuavam sua tradicional aliança com as autoridades clericais, procuravam adaptar-se às necessidades do século da razão. Cada súdito-cidadão deveria receber o tipo de formação mais adequado para poder tornar-se útil e dar os melhores rendimentos possíveis para o sistema econômico e o bem estar social. (p. 16)

Ainda segundo Bolle, tais intelectuais semi-obedientes e semi-rebeldes conseguiram junto ao poder da época fortalecer o sistema educacional da Alemanha, ao mesmo tempo, em contrapartida, foi-se forjando a idéia de algo que não poderia ser obtido apenas por meio da educação, algo que exigisse "independência, liberdade, autonomia”, isto é, a Bildung, e o principal autor responsável por esse "vôo emancipatório" seria Herder:

\footnotetext{
Ultrapassou as noções de "educação", "progresso" e mesmo "Aufklärung”, tomando seu lugar ao lado dos conceitos de "espírito", "cultura" e "humanidade”. Bildung, segundo Herder, é o conceito central para todos os que estão empenhados no desenvolvimento físico, psíquico e intelectual do ser humano. (ibid., p. 18)
}

O problema, segundo Bolle, é que o conceito de Bildung ficou de tal modo intrincado com a linguagem idealista que até hoje é difícil usá-lo para fins pragmáticos. Com o intuito de atingir tais fins ele justifica o retorno aos "textos da época em que a aventura da formação começou", como, por exemplo, ao romance fundador do Bildungsroman: Os Anos de Aprendizado de Wilhelm Meister, de Goethe, o qual o autor analisa mais detidamente no trabalho citado, e ao qual dedicaremos também uma sessão específica.

Antes disso, porém, faremos apenas uma pequena consideração sobre a tradução de Bildung no texto de Adorno que nos serve de principal referência quanto a este conceito.

Os tradutores para o português de Theorie der Halbbildung, preferiram manter no título Teoria da Semicultura ao invés de Teoria da Semiformação (como nós preferimos). Segundo eles, Bildung “indica, ao mesmo tempo, formação cultural e cultura. Portanto, o título original - Halbbildung - pode assumir, ora um, ora outro dos dois sentidos" (ADORNO, 1996, p. 410, nota do tradutor). Acreditamos que na versão em português essa ambigüidade 
na tradução torna a interpretação do texto confusa em face da presença constante da outra palavra em alemão para cultura, Kultur. Nosso cotejamento da tradução em português com o original em alemão nos faria optar pela tradução preferencial de Bildung por formação. Mesmo a expressão formação cultural não acreditamos de todo apropriada, pois pode dar margem a se pensar que exista uma formação fora da cultura (Kultur), o que, no pensamento adorniano, seria um equívoco. Para Adorno, a formação (Bildung) é "a cultura [Kultur] tomada pelo lado de sua apropriação subjetiva" (ibid., p. 389), e, portanto, é um desenvolvimento da cultura, sempre.

"Formação cultural", a nosso ver, remete a uma idéia de acumulação de conhecimentos que um indivíduo já formado tem com os bens culturais. Esta não é a posição de Adorno. Tal idéia pressuporia uma separação entre espiritual e material - como vimos, o material considerado por vezes como natureza, por vezes como civilização -, ficando a cultura do lado do espírito, separação que é ideológica. Apenas adiantando um pouco, vejamos o que ele diz mais ao final do texto em questão:

\footnotetext{
Max Frisch observou que havia pessoas que se dedicavam, com paixão e compreensão, aos chamados bens culturais, e que, no entanto, puderam se encarregar tranquilamente da práxis assassina do nacional-socialismo. Tal fato não apenas indica uma consciência progressivamente dissociada, mas sobretudo dá um desmentido objetivo ao conteúdo daqueles bens culturais - a humanidade e tudo o que lhe for inerente - enquanto sejam apenas bens, com sentido isolado, dissociado da implantação das coisas humanas. A formação que se esquece disso, que descansa em si mesma e se absolutiza, acaba por se converter em semiformação. (ibid., pp. 389-39o)
}

Mais tarde voltaremos à especificidade do problema acima tratado, por ora nos interessa apenas notar que a formação, para Adorno, não é algo que possa ser considerada em separado do resto da cultura, e, quando assim acontece, isso já é uma marca do que ele chama de semiformação.

\section{Bildung e o Wilhelm Meister de Goethe}

Não é certamente, nossa intenção, dar conta da complexidade envolvida na escrita, publicação e recepção de Os Anos de Aprendizado de Wilhelm Meister, publicado na Alemanha 
entre os anos de 1795 e 1796. Sabe-se, por exemplo, que o romance teve suas primeiras tentativas de redação comprovadas já em 1777, e que Goethe escreveu uma primeira versão de os Anos de Aprendizado intitulada A Missão Teatral de Wilhelm Meister, só redescoberta em 1910 (LUKÁcs, 2009 [1936], p. 581). Sabe-se também que provavelmente foi sob a influência de Schiller que Goethe resolveu retomar o projeto (BENJAMIN, 2009b [1926-1928], p. 159). E sabe-se da recepção cáustica por Novalis, segundo o qual Meister é um livro "fatal e tolo"; e entusiástica por Schlegel, que disse a famosa frase: "As três grandes tendências de nossa era são a Doutrina das Ciências [de Fichte], Wilhelm Meister e a Revolução Francesa" (MAZZARI, 2009, p. 7). Tanto nas referências dadas acima, quanto em Bolle (1997) pode-se encontrar análises mais amplas e cuidadosas da obra em questão. ${ }^{32}$ Faremos aqui apenas um pequeno recorte com a intenção de caracterizar em linhas gerais o que é a idéia de formação e suas contradições apresentadas nesse livro para que depois possamos entender melhor a formação possível hoje, segundo Adorno, e sua relação com essa idéia "clássica" de formação.

Em resumo, o romance conta a história de Wilhelm, burguês de nascimento, que a partir de uma experiência marcante com teatro de fantoches na infância persegue durante a juventude o ideal do teatro como lugar em que é possível viver de um modo que é recusado aos burgueses, e, portanto, recusado a ele também. Ele associa a formação para o teatro com a formação da nobreza, onde o "aparecer" prevalece sobre o "ser" (útil) burguês, e acaba vivendo um tempo com uma trupe. Essa é a primeira parte do romance, ao final dela podemos ver certa desilusão do herói com o teatro e a nobreza (tanto alguns nobres se mostram o contrário de seu ideal de formação, quanto as pessoas envolvidas no teatro se mostram tão burguesas quanto seus familiares). Até esse ponto a formação aparece como um processo pessoal e auto-determinado (para o burguês, o nobre já a teria "naturalmente"), porém não muito realista. Na segunda parte testemunhamos o contato de Wilhelm com a Sociedade da Torre, um grupo de pessoas, em sua maioria oriundas da nobreza (mas que realizam "casamentos desiguais", isto é, entre nobres e burgueses), os quais, descobrimos, vinham acompanhando e orientando veladamente

32 Recomendamos ainda a correspondência entre os dois autores publicada recentemente no Brasil, onde encontramos uma rica discussão pelos dois grandes nomes do classicismo alemão sobre o processo de produção da obra durante seu desenvolvimento. Ver Goethe e Schiller (2010). 
o caminho de formação do herói. Nessa parte do romance, a formação toma um caráter mais social, educativo e pragmático. A diferença, nas palavras do narrador do romance, é que antes Wilhelm "ignorava que é do feitio de todas as pessoas que dão grande importância à sua formação interior negligenciar por completo suas condições exteriores" e "pela primeira vez parecia inteirar-se agora de que necessitava de meios exteriores para agir de maneira estável" (GOETHE, 2009 [1795-1796], p. 468).

A diferença entre as duas partes do romance não é desprezível, porém, como nos mostra Lukács (2009), o ideal de formação humanista perpassa as duas partes, e mesmo quando toma o caráter educativo, este deixa espaço para a autonomia. Jarno, membro da Torre, por exemplo, em determinado momento fala a Wilhelm:

\begin{abstract}
É bom que o homem que pela primeira vez entra no mundo faça uma grande idéia de si próprio, pense em obter-se muitas vantagens e procure fazer todo o possível; mas quando sua formação atinge um certo grau, é vantajoso que aprenda a se perder numa grande massa, aprenda a viver para outros e a se esquecer de si mesmo numa atividade apropriada ao dever. Só então aprende a conhecer a si mesmo, pois é a ação que verdadeiramente nos compara aos outros. (GOETHE, op. cit., p.469)
\end{abstract}

E um pouco mais à frente Wilhelm ouve do abade, outro membro da Torre:

\footnotetext{
Não é obrigação do educador de homens preservá-los do erro, mas sim orientar o errado; e mais, a sabedoria dos mestres está em deixar que o errado sorva de taças repletas seu erro. Quem só saboreia parcialmente seu erro, nele se mantém por muito tempo, alegra-se dele como de uma felicidade rara; mas quem o esgota por completo, deve reconhecê-lo como erro, conquanto não seja demente. (pp. 470-471)
}

Esses dois trechos, com opiniões que o autor provavelmente compartilhava, mostram como Goethe era contrário a prescrições educativas ou morais rígidas. Se a formação na primeira parte do romance, pelos olhos da segunda, é considerada pouco realista, porém não deixa de ser necessária. O erro, bem ao gosto da dialética, não é somente falsidade, contém também algo da verdade.

Goethe teve o poder de expor no romance o problema da formação de sua época com a sutileza de não deixar de fora as contradições que o engendravam. Como vimos a propósito de Kant, Goethe provavelmente partilhava da opinião de que não seria uma revolução sangrenta que mudaria a sociedade, e sim uma mudança do pensamento; porém a transformação do pensamento no nível puramente individual é falsa, ou ao menos, frágil, se não houver uma mudança 
social correspondente. Por isso, como nos diz Lukács (2009), a realização da formação humanista, na segunda parte, é social. Contudo, ainda segundo esse autor, e aqui entra outra sutileza dialética de Goethe, essa formação social não se dá de forma generalizada no romance, mas numa sociedade fechada como a da Torre. Isso mostraria como o autor tinha consciência da distância efetiva da realização desse ideal de forma mais ampla, sem abandoná-lo, enquanto utopia.

Vejamos agora um pouco mais de perto uma passagem da primeira parte do romance, a fim de buscar alguns elementos estruturadores do que Goethe considerava a formação, sem perder de vista a ressalva dialética que constitui a segunda parte.

O trecho que reproduziremos a seguir é a parte substancial da carta que Wilhelm envia a seu amigo de infância e então cunhado Werner, que assumira os negócios da família com a morte do pai do herói. Nela, Wilhelm justifica sua estadia com a trupe, ao mesmo tempo em que tem a oportunidade de explicitar seu ideal de formação: ${ }^{33}$

Para dizer-te em uma palavra: instruir-me a mim mesmo, tal como sou, tem sido obscuramente meu desejo e minha intenção, desde a infância. Ainda conservo essa disposição, com a diferença de que agora vislumbro com mais clareza os meios que me permitirão realizá-los. Tenho visto mais mundo que tu crês, e dele me tenho servido melhor que tu imaginas. Atente, portanto àquilo que digo, ainda que não vá ao encontro de tuas opiniões.

Fosse eu um nobre e bem depressa estaria suprimida nossa desavença; mas, como nada mais sou do que um burguês, devo seguir um caminho próprio, e espero que venhas a me compreender. Ignoro o que se passa nos países estrangeiros, mas sei que na Alemanha só a um nobre é possível uma certa formação geral, e pessoal, se me permites dizer. Um burguês pode adquirir méritos e desenvolver seu espírito a mais não poder, mas sua personalidade se perde, apresente-se ele como quiser. Enquanto para o nobre, que se relaciona com as mais distintas pessoas, é um dever conferir a si mesmo um porte distinto, e esse porte, já que a ele nunca estarão cerradas portas nem portões, transforma-se num porte espontâneo, pois deve pagar por sua aparência, por sua pessoa, seja na corte ou no exército, de modo que tem ele razão em atribuir uma importância a elas e demonstrar que atribui alguma a elas. Uma certa graça majestosa nas coisas corriqueiras, uma espécie de ligeira graciosidade nas coisas sérias e importantes assentam-lhe bem, pois assim deixa ver que onde quer que esteja conserva seu equilíbrio. É uma pessoa pública, e quanto mais requintados seus gestos, mais sonora sua voz e mais comedida e discreta toda sua maneira de ser, mais perfeito ele é. Contanto que se mantenha sempre o mesmo diante de grandes e pequenos, diante de amigos e parentes, então não haverá nada nele para se criticar, nem se poderá desejar-lhe qualquer outra coisa. Que seja frio, mas compreensivo. Dissimulado, mas inteligente. Se souber dominarse exteriormente em qualquer momento de sua vida, ninguém haverá de lhe fazer

33 Segundo Bolle (1997): “A forma escolhida é a carta, muito adequada para o indivíduo esclarecer para si próprio, no ato de comunicação com o interlocutor, o que se passa em seu íntimo, forma que marcou os romances epistolares da época, como Pamela (1740) e Clarissa, (1747-1748), de Richardson, e o romance de estréia de Goethe, A Paixão do Jovem Werther (1774)" (p. 22). 
outras exigências, e tudo o mais que traz em si e a seu redor - capacidade, talento, riqueza -, tudo isso não parecerá senão um acréscimo.

Imagina, agora, um burguês qualquer que pensasse ter uma certa pretensão a essas prerrogativas; haveria de fracassar por completo e seria tanto mais infeliz quanto mais sua natureza lhe tivesse dado capacidade e inclinação para tal.

Se, na vida corrente, o nobre não conhece limites, se é possível fazer-se dele um rei ou uma figura real, pode portanto apresentar-se onde quer que seja com uma consciência tranqüila diante dos seus iguais, pode seguir adiante, para onde quer que seja, ao passo que ao burguês nada dá nem pode dar com sua personalidade. Aquele pode e deve aparentar, este só deve ser e, se pretende aparentar, tornase ridículo e de mau gosto. Aquele deve fazer e agir, este deve realizar e criar, desenvolver suas diversas faculdades para tornar-se útil, e já se presume que não há em sua natureza nenhuma harmonia, nem poderia haver, porque ele, para se fazer útil de um determinado modo, deve descuidar de todo o resto.

Por tal diferença culpa-se não a arrogância dos nobres nem a transigência dos burgueses, mas sim a própria constituição da sociedade; se um dia alguma coisa irá modificar-se, e o que se modificará, importa-me bem pouco; em suma, tenho de pensar em mim mesmo tal como estão agora as coisas, e no modo como hei de salvar a mim mesmo e conseguir o que para mim é uma necessidade indispensável.

Pois bem, tenho justamente uma inclinação irresistível por essa formação harmônica de minha natureza, negada a mim por meu nascimento. Desde que parti, tenho ganhado muito graças aos exercícios físicos. Tenho perdido muito de meu embaraço habitual e me apresento muito bem. Também tenho cultivado minha linguagem e minha voz e posso dizer, sem vaidade, que não me saio mal em sociedade. Mas não vou negar-te que a cada dia se torna mais irresistível meu impulso de me tornar uma pessoa pública, de agradar e atuar num círculo mais amplo. Some-se a isso minha inclinação pela poesia e por tudo quanto está relacionado com ela, e a necessidade de cultivar meu espírito e meu gosto, para que aos poucos, também no deleite dessas coisas sem as quais não posso passar, eu tome por bom e belo o que é verdadeiramente bom e belo. Já percebes que só no teatro posso encontrar tudo isso e que só nesse elemento posso mover-me e cultivar-me à vontade. Sobre os palcos, o homem culto aparece tão bem pessoalmente em seu brilho quanto nas classes superiores. Espírito e corpo devem a cada esforço marchar a passos juntos, e ali posso ser e parecer tão bem quanto em qualquer outra parte. Se procuro, ademais, outras ocupações, há nelas diversos tormentos mecânicos e posso impor à minha paciência um exercício cotidiano. (GOETHE, 2009, pp. 284-286)

Há muito para ser dito, obviamente, a partir desse longo trecho. Optamos, contudo, por apresentá-lo de modo contínuo para que não se perdesse a forma com que Goethe encadeia as idéias, forma tal que evidencia a tal sutileza dialética antes mencionada.

Por exemplo, falávamos há pouco sobre como a salvação individual da primeira parte do romance se mostra falsa na segunda. Porém, já nela, como vimos agora, o autor dá indícios de que a verdadeira formação deveria ser social, e que a salvação individual é quase um ato de desespero. Lembremos as passagens: "por tal diferença culpa-se [...] a própria constituição da sociedade" e "tenho de pensar em mim mesmo tal como estão agora as coisas, e no modo como hei de salvar a mim mesmo", e isso fica claro. 
Neste sentido, quanto às diferenças entre nobres e burgueses, note que quando Goethe usa a palavra "natureza", uma vez ela aparece mais próxima ao sentido de uma primeira natureza (tal como vimos na primeira parte), na passagem em que o herói diz que um burguês, nessa sociedade, será "tanto mais infeliz quanto mais sua natureza lhe tivesse dado capacidade e inclinação" para ser como um nobre; por outro lado, quando diz que não há na natureza do burguês nenhuma harmonia, porque ele tem que se fazer útil, está falando de algo social, ligado ao trabalho, e, portanto, aí se refere a algo mais próximo ao sentido de uma segunda natureza, a cultura. Ainda que a separação absoluta das duas, segundo Adorno, como vimos, seja falsa, a separação feita por Goethe sustenta a contradição de ser a natureza separada e ao mesmo tempo uma com a cultura, e mostra que já para ele a formação dependia da natureza (primeira) e se tornava uma natureza (segunda). Essa contradição fica clara num trecho logo em seguida aos dois relembrados: "tenho justamente uma inclinação irresistível [portanto algo natural, poder-se-ia pensar] por essa formação harmônica de minha natureza [por outro lado, agora a natureza pode ser formada e, portanto, é cultural], negada a mim por meu nascimento".

É esse ideal iluminista de igualdade (perante a lei, é sempre bom lembrar) um dos motivos do elogio que Schiller faz ao romance em questão:

\footnotetext{
Aliás, é muito bonito que o senhor, com todo o devido respeito por certas formas exteriores positivas, tão logo se trate de algo puramente humano, rejeite o berço e a classe social em sua total nulidade e - tão fácil - sem perder uma palavra sequer sobre o assunto. (GOETHE; SCHILLER, 2010 [1794-1803], p. 86)
}

À parte da separação feita por Schiller aqui entre primeira e segunda natureza ser menos sutil que no Meister, com seu "puramente humano", queremos chamar a atenção agora, tanto nessa citação de Schiller quanto no texto reproduzido do Meister, o "devido respeito por certas formas exteriores positivas". Isto é, note-se como a solução goethiana para o conflito entre nobreza e burguesia não inclui a barbárie da aniquilação da nobreza, não inclui a guilhotina. Pelo contrário, Goethe se manifesta fortemente contra a divisão social pelo nascimento sem, entretanto, deixar de lado o fato de que essa divisão social produzia algo desejável, que havia algo no modo de vida do nobre que, apesar de baseado no privilégio (e por isso ser condenável, em parte), não podia ser pura e simplesmente jogado fora por causa disso; que o modo de vida 
burguês perdeu algo muito importante que havia no modo de vida da nobreza, a saber, a diferença entre "ser" e "aparecer".

Como se pode notar, ao nobre cabia "aparecer" (scheinen), por isso aquilo que para o burguês seria um detalhe, como os gestos, a voz, a maneira de ser, para o nobre é essencial; enquanto ao burguês cabia apenas "ser" (sein), acima de tudo, útil, e, como vimos, "para se fazer útil de um determinado modo, deve descuidar de todo o resto".

Segundo Bolle (1997) a formação pelo teatro seria a síntese perfeita, à primeira vista, entre o Sein e o Schein, e não apenas, como se poderia pensar, um desejo de ascensão social. O Meister contém uma aguda análise da sociedade e no decorrer do romance ele se desilude com a nobreza e com o teatro. Mas não acreditamos que essa desilusão se deva à falta de validade dessas duas categorias, e sim que os objetos às quais eram atribuídas, o aparecer à nobreza e ao teatro, em especial, não se mostraram a altura da sua utopia. Por ora, não iremos mais longe do que isso. A propósito do conceito de formação em Adorno veremos como a diferença entre ser e aparecer vai assumir, a seu modo, um papel decisivo também para nosso autor.

Uma última consideração que deve ser feita diz respeito à continuidade da obra, já que Goethe escreveu posteriormente Anos de Andanças de Wilhelm Meister, na qual, segundo Bolle (1997), "presenciamos a reintegração de Wilhelm na sociedade burguesa, através da decisão por uma profissão ‘socialmente útil': a do médico”. A partir disso Bolle pergunta:

\footnotetext{
Vingança da "educação" realista contra os altos vôos da Bildung, ou ironia do velho Goethe, mostrando como é limitado o projeto histórico, político e cultural de sua classe de origem? (p. 32)
}

Porém, o sentido desse outro romance, ou as possíveis mudanças na concepção de Goethe a respeito da formação, ao longo de sua vida e obra, não nos interessa no momento, já que é durante o período de Os Anos de Aprendizado que se dá a fase mais intensa de comunicação entre Goethe e Schiller, e a partir de onde o conceito de Bildung ganha suas principais feições modernas. 


\section{Formação e a Educação Estética de Schiller}

Adorno ter buscado em Schiller o conceito clássico de formação não é fato isolado em seu pensamento. Segundo Hullot-Kentor (2006a), a estética de Schiller é o ponto crucial entre Kant e Adorno, e cada elemento da análise da dialética do esclarecimento, assim como a relação desta com a estética, tem seu precedente na estética de Schiller, "a começar pela própria figura histórico/natural da dialética do esclarecimento” (p. 34, tradução livre).

Já vimos, no capítulo a respeito dos conceitos de cultura, natureza e barbárie, uma citação de Schiller que colocava o problema então apresentado em termos comparáveis à primeira frase da Dialética do Esclarecimento. Não é nosso objetivo procurar toda a riqueza possível de correspondências entre Schiller e Adorno. Apenas apresentaremos brevemente alguns conceitos centrais da filosofia de Schiller, e de Kant, naquilo que for essencial para a compreensão do primeiro.

Tanto em Eagleton (1993) quanto em Rosenfeld (1991), podemos encontrar algumas das idéias desses filósofos expostas com concisão, aos quais remetemos. Nossa apresentação, com a ajuda destes, será ainda mais breve, tendo em vista nossos objetivos.

Basicamente, a parte mais conhecida e influente da teoria kantiana são as três críticas: a Crítica da Razão Pura, que trata daquilo que pode ser conhecido pelo entendimento, a natureza - reino da necessidade; a Crítica da Razão Prática, que trata daquilo que possa ser conhecido pela razão, as leis morais - reino da liberdade; e a Crítica da Faculdade do Juízo, que trata de uma esfera intermediária entre a natureza e a liberdade, os juízos estéticos. Ele próprio resume as duas primeiras, na introdução da terceira, do seguinte modo:

[...] existem somente duas espécies de conceitos que precisamente permitem outros tantos princípios da possibilidade dos seus objetos. Referimo-nos aos conceitos de natureza e ao de liberdade. Ora, como os primeiros tornam possível um conhecimento teórico segundo princípios a priori, e o segundo em relação a estes comporta já em si mesmo somente um princípio negativo (de simples oposição) e todavia em contrapartida institui para a determinação da vontade princípios que lhe conferem uma maior extensão, então a Filosofia é corretamente dividida em duas partes completamente diferentes segundos os princípios, isto é, em teórica, como filosofia da natureza, e em prática, como filosofia da moral (na verdade é assim que se designa a legislação prática da razão segundo o conceito da liberdade). (KANT, 2005 [1790], p. 15) 
Essa separação entre filosofia da natureza e filosofia da moral ocorre porque, para

Kant, a essência última das coisas, o nômeno, não pode ser conhecido pelos sentidos, apenas o fenômeno. Segundo Eagleton (1993):

Enquanto na dimensão fenomenal estamos sujeitos à causalidade mecânica, nosso ser numenal trama, por trás ou através dessa dimensão, algum fantástico artefato ou maravilhoso poema, pois o sujeito livre dirige suas ações não em termos de causa e efeito mecânicos, mas articulado à totalidade teleológica que é a Razão. (p. 63)

Vejamos nas palavras de Kant, num trecho em que o nômeno aparece enquanto “supra-sensível”, como ele explica essa separação:

\begin{abstract}
Mas o fato de estes dois diferentes domínios [...] não constituírem um só tem origem em que na verdade o conceito de natureza representa os seus objetos na intuição, mas não como coisas em si mesmas, mas na qualidade de simples fenômenos; em contrapartida, o conceito de liberdade representa no seu objeto uma coisa em si mesma, mas não na intuição. Por conseguinte, nenhuma das duas pode fornecer um conhecimento teórico do seu objeto (e até do sujeito pensante) como coisa em si, o que seria o supra-sensível, cuja idéia na verdade tem que se colocar na base de todos aqueles objetos da experiência, não se podendo todavia nunca elevá-la e alargá-la a um conhecimento. (KANT, op. cit., p. 19)
\end{abstract}

Isto é, o entendimento representa os objetos na intuição, ${ }^{34}$ mas apenas o seu aspecto fenomênico, não a coisa em si; a razão, por outro lado, trata da coisa em si, mas não a representa na intuição. Por isso o conhecimento teórico da coisa em si, do nômeno, é impossível; somente seu conhecimento prático.

Apesar dos reinos da natureza e da liberdade parecerem à primeira vista inconciliáveis, é impossível para Kant admitir uma oposição completa entre os dois, já que o homem deve atuar como ser moral no mundo da natureza. Se ele admitisse esta oposição, esse atuar seria impossível:

\footnotetext{
Ainda que na verdade subsista um abismo intransponível entre o domínio do conceito da natureza, enquanto sensível, e o do conceito de liberdade, como supra-sensível, de tal modo que nenhuma passagem é possível do primeiro para o segundo [...] contudo este último deve ter uma influência sobre aquele, isto é, o conceito de liberdade deve tornar efetivo no mundo dos sentidos o fim colocado pelas suas leis [...] (ibid., p. 20)
}

34 Intuição, aqui, não no sentido cotidiano, onde muitas vezes se aproxima do sentido de "premonição", mas sim no sentido mais próximo ao de "percepção". 
E por isso, pela necessidade kantiana de que o reino numenal tenha influência sobre

o fenomenal, que a liberdade possa influir na natureza, é que ele vai pensar no domínio estético como o da mediação entre os dois. Nas palavras de Rosenfeld (2009):

Kant concebeu entre a função teórica do nosso intelecto - que se refere ao conhecimento daquilo que realmente é - e a função prática da nossa razão - que se refere ao conhecimento das leis morais, isto é, daquilo que não é mas deve ser - uma terceira função, inteiramente autônoma, intermediária entre as outras. Esta terceira função, numa das suas especificações, constitui o gosto estético que, portanto, não pode ser reduzido nem ao conhecimento lógico-científico, nem à razão enquanto determinadora do imperativo moral (isto é, das normas da vontade). (p. 18)

O reino da estética seria, assim, o elo entre os dois, que manteria em termos a oposição, porém, integrando-os. Vejamos o que Eagleton (1993) nos diz a respeito:

\begin{abstract}
O prazer da estética é, em parte, o resultado da surpresa de que assim aconteça [o mundo empírico parecer se conformar aos fins da razão prática]. Trata-se da sorte de um maravilhoso acaso que certos fenômenos pareçam mostrar uma unidade de propósito, unidade que não é dedutível como necessária a partir de premissas lógicas. A ocorrência parece fortuita, contingente e não-subsumível a um conceito de entendimento; mas ao mesmo tempo ela surge Como se pudesse de alguma forma se submeter a um tal conceito, como se se conformasse espontaneamente a uma tal lei, mesmo que nós não possamos dizer que lei é essa. Se não há nenhuma lei real a que possamos subsumir um tal fenômeno, então esta lei parece ser algo inscrito na sua própria forma material, inseparável de sua particularidade singular, uma espécie de lei contingente ou fortuita acessível intuitivamente a nós na coisa, mas completamente inteorizável. Nas operações da razão pura, colocamos algo particular sob um conceito universal, assim escondendo sua especificidade sob a generalidade; nas questões da razão prática, subordinamos o particular a uma máxima universal. No juízo estético, no entanto, temos a sensação curiosa de uma totalidade de acordo com a lei, indissociável de nossa intuição da forma imediata da coisa. A Natureza parece animada por uma finalidade própria que desafia o entendimento; e esta finalidade, por uma agradável ambigüidade, parece, ao mesmo tempo, uma lei à qual o objeto se conforma e nada menos que a estrutura irredutível do objeto ele mesmo. (p. 65-66)
\end{abstract}

O juízo estético não envolve conceitos propriamente, como o entendimento, mas envolve nossa capacidade conceitual e, por isso, participa do entendimento. Ao mesmo tempo, o juízo estético, apesar de estar em conformidade a fins, não tem uma finalidade tal qual o exige a lei moral, assim, participa da razão sem se confundir com ela. Essa forma de integração é o livre jogo das nossas faculdades. E esse é o ponto que nos interessa especialmente aqui, e que retomaremos a propósito de Schiller. Esse jogo das faculdades no juízo estético é livre, nos diz Kant, porque quando seguimos os impulsos da natureza não somos livres, tampouco quando seguimos uma lei da razão. A liberdade, para Kant, associada à razão, convém lem- 
brar, não é a de livre escolha, é de outra natureza, pois não há espaço para uma escolha onde impera uma lei moral:

\begin{abstract}
Um objeto da inclinação e um que nos é imposto ao desejo mediante uma lei da razão não nos deixam nenhuma liberdade para fazer de qualquer coisa um objeto de prazer para nós mesmos. Todo interesse pressupõe necessidade ou a produz; e, enquanto fundamento determinante da aprovação, ele não deixa mais o juízo sobre o objeto ser livre. (KANT, op. cit., p. 55)
\end{abstract}

Contudo, tampouco a liberdade do juízo estético significa "livre escolha"; isso faria do gosto algo puramente individual. Diferentemente do agradável (aos sentidos) que pode ser para um e não ser para outro, nos diz Kant, o juízo de gosto exige a unanimidade. Quando se diz que uma coisa é bela, não se está querendo dizer que ela seja bela somente para você. O juízo de gosto é um universal "comparativamente" e "socialmente", sem ser universal na forma de conceitos:

\begin{abstract}
Mas aqui a universalidade é tomada só comparativamente; e então há somente regras gerais (como o são todas as empíricas), não universais, como as que o juízo de gosto sobre o belo toma a seu encargo ou reivindica. Tratase de um juízo em referência à sociabilidade, na medida que ela se baseia em regras empíricas. Com respeito ao bom, os juízos na verdade também reivindicam, com razão, validade para qualquer um; todavia, o bom é representado somente por um conceito como objeto de uma complacência universal, o que não é o caso nem do agradável nem do belo. (ibid., p. 57-58)
\end{abstract}

O livre jogo se refere a uma liberdade frente ao conceito - o que para Kant é uma liberdade de determinação objetiva -, mas não é absolutamente livre, sua determinação provém das nossas próprias faculdades, é uma determinação subjetiva. Subjetiva, porém, não é particular; é subjetiva enquanto válida para todas as subjetividades. Vejamos outra passagem de Kant:

Portanto, as faculdades do ânimo, cuja reunião (em certas relações) constitui o gênio, são as da imaginação e do entendimento. Só que, visto que no seu uso para o conhecimento a faculdade da imaginação está submetida à coerção do entendimento e à limitação de ser adequada ao conceito do mesmo; e que do ponto de vista estético contrariamente a faculdade da imaginação é livre para fornecer, além daquela concordância com o conceito, todavia espontaneamente, uma matéria rica e não elaborada para o entendimento, a qual este em seu conceito não considerou e a qual este, porém, aplica não tanto objetivamente para o conhecimento, quanto subjetivamente para a vivificação das faculdades de conhecimento, indiretamente, portanto, também para conhecimento; assim o gênio consiste na feliz disposição, que nenhuma ciência pode ensinar e nenhum estudo pode exercitar, de encontrar idéias para um conceito dado e, por outro lado, de encontrar para elas a expressão pela qual a disposição subjetiva do ânimo daí resultante, enquanto acompanhamento de um conceito, pode ser comunicada a outros. O último talento é propriamente aquilo que se denomina espírito; pois expressar o inefável no estado de ânimo por ocasião 
de uma certa representação e torná-lo universalmente comunicável - quer a expressão consista na linguagem, na pintura ou na arte plástica - requer uma faculdade de apreender o jogo fugaz da faculdade da imaginação e reuni-lo em um conceito que coerção das regras (e que justamente por isso é original e ao mesmo tempo inaugura uma nova regra, que não pode ser inferida de quaisquer princípios ou exemplos anteriores). (ibid., pp. 162-163, grifo nosso)

Nos dois trechos grifados fica claro que a liberdade e o jogo são atributos da faculdade da imaginação e não da pessoa. Note também que apesar de apenas girar em torno dos conceitos e, por isso, não estar sob a coerção das regras, ao mesmo tempo, o livre jogo da imaginação inaugura uma nova regra.

Não nos interessa no momento ir mais longe do que isso em Kant, o que nos interessa em especial agora é entender porque para Schiller, essa terceira via, a estética, em Kant, ficou incompleta.

Segundo Rosenfeld (2009), Kant esboçou uma teoria sobre esse reino da estética “somente na medida em que constituía viga importante na cúpula do seu edifício filosófico, que se apóia essencialmente nas colunas da epistemologia e da teoria moral” (p. 21), já que ele não tinha grande "familiaridade com as musas"35; o que por outro lado, não faltava a Schiller.

O problema de Kant, para Schiller, é que o seu sistema mantém uma primazia do reino moral sobre o estético, e Schiller vai inverter essa relação, apesar de partir, a princípio, da primazia do moral. Para entendermos como isso se dá, cabe aqui retomarmos o problema entre o ideal de emancipação do Iluminismo, a Revolução Francesa e a barbárie dela decorrente, que já trouxemos a propósito de Kant e Goethe. Schiller nos diz:

\footnotetext{
A tentativa do povo francês de estabelecer-se nos seus sagrados direitos humanos e conquistar uma liberdade política trouxe a lume apenas a incapacidade e a indignidade do mesmo, e lançou de volta à barbárie e à servidão não apenas este povo infeliz, mas, com ele, também uma considerável parte da Europa, e um século inteiro. O momento era o mais favorável, mas encontrou uma geração corrompida que não mais lhe era merecedora e não soube nem dignificá-lo nem utilizá-lo. O uso que ela fez e faz deste grande presente do acaso demonstra incontestavelmente que o gênero humano ainda não se livrou da violência tutelar, que o regime liberal da razão chega demasiado cedo onde mal se está pronta para se defender da brutal violência da animalidade, e que aquele, a quem ainda falta muito para a liberdade humana, ainda não está maduro para a liberdade civil. (SCHILLER, 2009b [1793], pp. 74-75)
}

35 Adorno mesmo fala que Kant e Hegel foram os últimos que puderam escrever uma grande estética sem entenderem nada de arte (ADORNO, 2003f, p. 123). 
Aqui já encontramos o cerne da diferença que marca o pensamento de Schiller em relação ao filósofo de Königsberg: o problema da falta de emancipação não advém apenas da preguiça e da covardia, como em Resposta à Pergunta: Que É Esclarecimento? Neste, Kant nos diz:

A preguiça e a covardia são as causas pelas quais uma tão grande parte dos homens, depois que a natureza de há muito os libertou de uma direção estranha (naturaliter maiorenners), continuem no entanto de bom grado menores durante toda a vida. (KANT, 2009, p. 64)

O que mantém o homem sob a "violência tutelar", para Schiller, é o "regime liberal da razão" chegar cedo demais onde o homem ainda não se livrou da "brutal violência da animalidade", isto é, o problema se dá na passagem da natureza à liberdade. E é aí justamente que entra a estética. Como nos diz Rosenfeld (2009):

\begin{abstract}
O problema que Schiller parte é de ordem política: O Estado, a organização política da sociedade de então devem ser transformados segundo os postulados da razão prática, isto é, segundo os imperativos da moral. No entanto, com os excessos da Revolução Francesa diante dos olhos, Schiller não admite a solução revolucionária, apesar do seu passado que lhe granjeara a homenagem da Convenção Nacional da França revolucionária. Desta forma, o Estado ideal torna-se um problema de educação. Cabe a uma nova humanidade, íntegra e perfeita, criar o Estado moral, e não ao Estado moral, imposto pela revolução, criar a nova humanidade. Assim, as Cartas $^{36}$ [sobre a Educação Estética da Humanidade] exaltam a educação estética e o "terceiro caráter" (o estético) como meio transitório para chegar-se ao estágio moral para transformar os postulados morais em "práxis cotidiana". (p. 24)
\end{abstract}

Até aqui, aparentemente, o reino moral mantém a sua primazia, já que a educação estética é um meio transitório para o moral se concretizar. Porém existe algo de muito importante que vai ficando mais claro ao longo das Cartas: o meio vai se tornando fim último, e o "homem estético" passa a ser o ideal absoluto, "único em que o homem é integralmente homem” (loc. cit.).

36 Segundo Rosenfeld (2009): “A obra 'Sobre a Educação Estética da Humanidade, numa série de cartas', nasceu, de fato, de uma série de cartas enviadas ao príncipe dinamarquês Frederico Cristiano de Augustenburg, que lhe oferecera em 1791, por três anos, uma pensão de mil 'Taler' anuais - dádiva que possibilitou ao poeta o intenso estudo da obra de Kant. Desde o início de 1793, Schiller redigiu, em homenagem ao príncipe, as Cartas que desde logo se destinaram à publicação posterior. Mas, no início de 1794, o castelo de Christiansburg em Copenhague foi destruído por um incêndio, queimando também os originais das cartas de Schiller. Muito mais tarde foram encontradas algumas cópias fragmentárias, feitas por amigos estudiosos do príncipe. O próprio Schiller, porém, tornou a redigir as cartas nos fins de 1794 e início de 1795 e, nesta forma mais acadêmica e rígida, a obra chegou a nós" (p. 23). O que restou das cartas originais foi publicado no Brasil recentemente sob o título Cultura Estética e Liberdade (2009b). 
Essa é a chamada crítica ao rigorismo moral kantiano, por Schiller, em prol dos direitos da sensibilidade. A título de curiosidade, o tradutor Ricardo Barbosa, comentando tal crítica, nos conta, sobre a carta que Schiller enviou a Kant acompanhada de dois números da revista Die Horen, em que havia publicado dois terços das cartas. Kant respondeu chamando-as de excelentes e prometeu estudá-las, o que, infelizmente não chegou a cumprir. Ainda assim, continua Barbosa, Schiller ficou perplexo com a aceitação de Kant, em especial quanto à sua crítica ao rigorismo moral; o que chegou a mencionar em carta a Friedrich H. Jacobi escrita a 29 de junho de 1795:

\footnotetext{
Onde meramente derrubo e procedo ofensivamente contra outras opiniões, sou estritamente kantiano; apenas onde construo encontro-me em oposição a Kant. No entanto, ele me escreve dizendo que está inteiramente satisfeito com minha teoria: portanto, ainda não sei muito bem como me coloco diante dele. (schiller, 2009b, p. 6o, nota do tradutor)
}

Schiller não está apenas preocupado em defender a personalidade contra as forças da sensação, está igualmente preocupado em "resguardar a sensibilidade das intervenções da liberdade" (id., 2009a, p. 81).

Kant provavelmente não era uma leitura fácil nem para Schiller, e este recorreu, como muitos na sua época, aos comentários de Karl Leonhard Reinhold (1758-1823) para seu estudo. Segundo Rosenfeld, encontra-se nesse autor os conceitos de impulso material e formal dos quais Schiller partirá para a formulação de um outro, o impulso lúdico:

\footnotetext{
O primeiro é uma necessidade de receber (receptividade); o segundo uma aspiração de dar forma, aplicando a nossa espontaneidade. Aquele é sensível e empiricamente determinado; este é livre e aspira ao cumprimento do seu mais alto princípio formal, a lei moral. Sua satisfação é o ato moral. (ibid., p. 81, nota do tradutor)
}

Segundo Schiller, nas Cartas, quando o impulso sensível é determinante, o homem é controlado pelos sentidos, ele próprio então, sua personalidade, perde o conteúdo, pois o impulso sensível quer que o caráter modificador do tempo prevaleça, mas em modificação infinita, aquilo que é próprio do homem se perde. Quando o impulso formal, por outro lado, é determinante, o homem se coloca antes do mundo, e por isso perde também sua autonomia, porque o permanente do homem necessita do mutável do mundo para se manifestar. Segundo ele, no primeiro caso o homem "nunca será ele mesmo" e no segundo "nunca será outra coisa", e, portanto, nos dois casos "será zero". Por isso o homem necessita pôr um limite em ambos os impulsos. 
Já nesse ponto, em uma nota, Schiller nos fala sobre uma formação que se baseie apenas em um desses dois princípios, o formal, já que uma educação baseada no impulso sensível seria um puro abandono à natureza:

Igualmente difícil é determinar o que esfria e perturba mais nossa filantropia prática, se a violência de nossas inclinações ou a rigidez de nossos princípios, se o egoísmo de nossos sentidos ou o de nossa razão. Para que sejamos homens participantes, prestimosos e ativos, é necessário que colaborem os sentidos abertos e a energia do entendimento. Por louváveis que sejam nossos princípios, não poderemos ser razoáveis, bondosos ou humanos se faltar a faculdade de aprender fiel e verazmente a natureza do outro, se faltar a força de nos empenharmos em situações estranhas, de tornarmos nossos o sentimento alheio. Esta faculdade, porém, será sufocada na educação que recebemos e naquela que nos damos na medida mesmo em que procuramos quebrar o vigor das inclinações e fortificar o caráter pelos princípios. Por ser difícil o convívio da vivacidade do sentimento e da fidelidade aos princípios, apelamos para um meio mais simples, asseguramos o caráter pelo embotamento da sensibilidade, pois é infinitamente mais fácil obter paz de um adversário sem armas do que dominar um inimigo disposto e corajoso. Esta operação resume, em parte maior, aquilo que chamamos formar um homem, e isto no melhor sentido da palavra, quando significa um trabalho sobre a interioridade não apenas sobre o exterior. Um homem formado assim está, evidentemente, a coberto de tornar-se crua natureza ou de aparecer como tal. Ao mesmo tempo, entretanto estará escudado por princípios contra toda a sensação da natureza, impermeável exterior e interiormente a qualquer humanidade. (ibid., p. 83)

Aqui, Schiller descreve os efeitos nocivos de uma educação baseada apenas na razão, ao extirpar a sensação, perde-se também o contato com os outros homens, e perde-se a humanidade.

Com base na estética kantiana, Schiller vai formular o terceiro impulso, o lúdico, que seria o responsável por combinar a modificação à identidade, dar forma à matéria e realidade à forma. Esse impulso lúdico não deve ser confundido com os jogos "na vida real", e sim tem a ver com o livre jogo das funções mentais no prazer estético, tal como concebido por Kant e apresentado há pouco.

Lembremos que essa liberdade não é escolha arbitrária, nem se confunde com a liberdade da razão. Tanto é assim que Schiller sente a necessidade de diferenciar as duas liberdades:

Para evitar mal-entendidos, lembro que a liberdade de que falo não é aquela encontrada necessariamente no homem enquanto inteligência, liberdade esta que não lhe pode ser dada nem tomada; falo daquela que se funda em sua natureza mista. Quando age exclusivamente pela razão, o homem prova uma liberdade da primeira espécie; quando age racionalmente nos limites da matéria e materialmente, sob a lei da razão, prova uma liberdade da segunda espécie. A segunda poderia ser explicada somente por uma possibilidade natural da primeira. (ibid., p. 108) 
A liberdade do livre jogo "age materialmente", mas “sob a lei da razão". Isto é, o reino da sensação, da natureza, não impera, mas também não é renegado. Ser a segunda uma possibilidade natural da primeira, não quer dizer, entretanto, que seja menos importante. Vejamos como Schiller dá um giro no lugar reservado ao estético, por meio do seu conceito de impulso lúdico:

\begin{abstract}
A razão, por motivos transcendentais, coloca a exigência: é necessário que haja uma comunidade entre impulso formal e material, isto é, um impulso lúdico, pois que apenas a união de realidade e forma, de contingência e necessidade, de passividade e liberdade, completa o conceito de humanidade. (ibid., p. 89)
\end{abstract}

Note que a razão exige o impulso lúdico, o que, a princípio seria um acordo com a primazia do reino moral; porém, apenas aquilo proporcionado pelo impulso lúdico - a união entre impulso formal e material - é que completa o conceito de humanidade. Ou ainda, como ele diz em famosa passagem: o homem "somente é homem pleno quando joga" (ibid., p.92). Com isso, Schiller traz o estético ao primeiro plano.

Vejamos em uma nota de Schiller nas Cartas a respeito do termo "estético", tanto um resumo de sua apropriação de Kant, quanto algumas características por ele atribuídas ao estético que vão nos levar de volta ao conceito de formação tal como trabalhado aqui a respeito do Meister de Goethe:

Para leitores que não estejam familiarizados com a significação deste termo tão malbaratado pela ignorância, sirva de explicação o seguinte. Todas as coisas que de algum modo possam aparecer são pensáveis em quatro relações diversas. Uma coisa pode relacionar-se imediatamente com o nosso estado sensível (nossa existência, nosso bem-estar): esta é a sua condição física. Ela pode, também, relacionar-se com nosso entendimento, provendo conhecimento: esta é sua qualidade lógica.

Ela pode, ainda, relacionar-se com nossa vontade e ser considerada como objeto da opção de um ser racional: esta é sua condição moral. Ou, finalmente, ela pode relacionar-se ao todo de nossas diversas faculdades sem ser objeto determinado para uma isolada dentre elas: esta é sua qualidade estética. Um homem pode ser-nos agradável por prestimoso; pode, pelo diálogo, dar-nos o que pensar. Pode incutir respeito pelo seu caráter; finalmente, com independência disto tudo, sem que prendamos nosso juízo que lhe diz respeito a qualquer lei ou finalidade, ele pode ser aprazível à pura contemplação por sua simples maneira de aparecer. Nesta última qualidade, julgamo-lo esteticamente. Existe, assim, uma educação para a saúde, uma educação do pensamento, uma educação para a moralidade, uma educação para o gosto e a beleza. A última tem por fim conformar na máxima harmonia o todo de nossas faculdades sensíveis e espirituais. (ibid., p. 110, grifo nosso)

Não vemos aqui uma concepção de educação estética em grande parte semelhante à de formação presente no Meister de Goethe? A “simples maneira de aparecer”, característica do 
estado estético, é colocada em oposição à finalidade, tal qual o aparecer do nobre ao ser (útil) do burguês; e a falta de "harmonia", lembremos também, era uma das características deste último. Um pouco mais à frente do trecho citado, Schiller lança mão de outro termo que remeterá nossa lembrança ao romance de Goethe, justamente o termo "nobreza”. Falando sobre como a educação estética faz com que o homem inicie sua vida moral já na vida física, ele diz:

\footnotetext{
O homem deve, se me permitirdes a expressão, travar a guerra contra a matéria em seus próprios domínios, para isentar-se de lutar contra o terrível inimigo no campo sagrado da liberdade; deve aprender a desejar nobremente, para não ser forçado a querer, de modo sublime. Esta tarefa é realizada pela cultura estética [...] (ibid., pp. 123-124)
}

Sobre o uso do termo sublime, Rosenfeld, em nota de tradução, nos diz que, para Schiller, o termo significa dignidade, e a dignidade "é manifestação da resistência que o espírito autônomo opõe ao impulso natural" (ibid., p. 124). Como o ideal de formação humanista de Schiller envolve a harmonia, esse antagonismo que exige uma resistência da parte do espírito não se encaixa tão bem quanto o desejar nobremente.

Quanto ao significado de nobre aqui, o próprio Schiller nos esclarece:

Deve ser dito nobre o espírito que tenha o dom de tornar infinitos, pela maneira
de agir, mesmo o objeto mais mesquinho e a mais limitada empresa. É nobre
toda forma que imprime autonomia ao que, por natureza, deveria apenas
servir (ser somente meio). Um espírito nobre não se basta com ser livre; precisa
libertar todo o mais à sua volta, mesmo o inerte. Beleza, entretanto, é a única
expressão possível da liberdade enquanto manifestação sensível. (ibid., p. 122)

Isto é, desejar nobremente é, diferentemente de querer de modo sublime, por em harmonia o espiritual e o material, a liberdade e a natureza. E novamente aqui a oposição aparecer e ser (servir), do Meister de Goethe, ganha evidência. Vemos assim como Schiller realiza na sua filosofia aquilo que Goethe realiza no romance, exalta valores da nobreza, perdidos pela burguesia, mas assim como acontece por meio do programa da Sociedade da Torre e dos "casamentos desiguais" no Meister, Schiller desloca a nobreza do nascimento para a formação.

Barbosa indica como essa idéia de humanidade como fim em si mesmo, também presente na citação acima, remete à segunda formulação do imperativo categórico de Kant, na Fundamentação da Metafísica dos Costumes: "Aja de modo que uses a humanidade, tanto em 
tua pessoa como na pessoa de qualquer outro, sempre ao mesmo tempo como fim, nunca simplesmente como meio" 37 (KANT apud sCHILLER, 2009b, p. 73, nota do tradutor).

Cabe dizer ainda, trazendo o tema para a Teoria Crítica, que esse ideal de humanidade como harmonia entre natureza e liberdade de Schiller nos parece, em verdade, como disse Hullot-Kentor (2006a), um precedente da dialética do esclarecimento, de Adorno e Horkheimer. Em um dos trechos que restaram das primeiras cartas, Schiller nos diz, por exemplo:

A necessidade mais urgente da nossa época parece-me ser o enobrecimento dos sentimentos e a purificação ética da vontade, pois muito já foi feito pelo esclarecimento do entendimento. (p. 79)

Ou seja, o tema da reconciliação com a natureza, da Dialética do Esclarecimento, aparece antes em Schiller como harmonia entre o espiritual e o material. Se para Adorno o momento original de conciliação se encontra num passado mítico, não menos mítico é o passado à que Schiller remete a harmonia: a sociedade grega clássica. Note a referência explícita no seguinte trecho:

Por isso a arte também pode caminhar em meio a um século bárbaro e indigno pura como um ser celestial, tão logo ela permaneça recordandose apenas de sua elevada origem e não se rebaixa a si mesma a escrava de intenções e necessidades inferiores. Assim caminha ainda agora o espírito grego, em seus poucos resíduos [...] (sCHILLER, 2009b, pp. 82-83)

Veremos em outro momento como Adorno, obviamente, jamais aceitaria a idéia da arte conviver com a barbárie "pura como um ser celestial”, sendo que, como já vimos, ele chega mesmo a dizer que é "impossível escrever poemas depois de Auschwitz". Porém, o que veremos em mais detalhes, é que a arte continua, do mesmo modo, ocupando o lugar da utopia.

Note também como nas Cartas a Grécia antiga aparece em oposição à mecanização e fragmentação da vida:

A natureza de pólipo dos Estados gregos, nos quais cada indivíduo gozava uma vida independente e podia, quando necessário, elevar-se à totalidade, foi agora substituída por uma engenhosa engrenagem cuja vida mecânica, em sua totalidade, é formada pela composição de infinitas partículas sem vida [...] Eternamente acorrentado a uma pequena partícula do todo, o homem

37 KANT, I. Grundlegung zur Metaphysik der Sitten. In: Gesammelte Werke, vol. 4, Akademie-Ausgabe. p. 429. 
só pode formar-se enquanto partícula; ouvindo eternamente o mesmo ruído monótono da roda que ele aciona, o homem não desenvolve a harmonia de seu ser, e, em lugar de desdobrar em sua natureza a humanidade, tornouse mera cópia de sua ocupação, de sua ciência. (id., 2009a, pp. 52-53)

Difícil não associar essa descrição à descrição do homem moderno na Dialética do Esclarecimento de Adorno e Horkheimer ou na Ideologia da Sociedade Industrial (1967 [1964]) de Marcuse.

Que Schiller tivesse consciência ou não do caráter utópico da sua Grécia não nos ocuparemos aqui. Porém, vale lembrar, diversos comentadores apontam como a concepção de antigüidade clássica grega de Schiller, e de Goethe, contendo "ideais humanistas de validade aparentemente intemporal" (sCHILLER, 2009b, p. 82, nota do tradutor) advém de Winckelmann (1717-1768), fundador da ciência da arqueologia, e o qual teve uma coletânea editada pelo próprio Goethe..$^{38}$

Podemos dizer, a partir do estudo de Süssekind (2008) que uma das características principais do programa estético de Winckelmann, sintetizado pela famosa frase: "o único caminho para nos tornarmos grandes, se possível inimitáveis, é a imitação dos gregos”, é justamente o que chamamos de seu caráter utópico. Winckelmann propunha uma imitação dos gregos como os gregos imitavam a natureza; não mera cópia, mas indo além dela. A esse respeito, Süssekind (2008) lembra os exemplos de Winckelmann no campo da escultura:

\footnotetext{
Winckelmann exemplifica a superação da semelhança com a natureza em duas estátuas gregas: o Antinous Admirandus, cujo corpo perfeito a própria natureza estaria longe de criar, e o Apolo de Belvedere, que põe diante dos nossos olhos "as proporções mais do que humanas de uma bela divindade”, algo que mesmo a nossa imaginação não pode superar. (p. 72)
}

O retorno aos gregos, do neoclassicismo, se contentou com a mera cópia das formas consagradas gregas. Já Goethe e Schiller, geralmente chamados de os autores do Classicismo de Weimer, entenderam melhor os princípios de Winckelmann e, em sua imitação da natureza e do homem, imaginaram uma outra natureza possível e um outro ser humano possível, reconciliados (mas claro, esse ideal não apareceu livre de contradições). 
A nosso ver, extrapolando um pouco, a verdadeira Grécia de Wickelmann, Goethe e Schiller era a utopia, tal qual tomará parte no pensamento de Adorno; e a imitação que eles propunham, assim como seu poder de reconciliação, era, de certo modo, a mesma que ganhará corpo, em Adorno, por meio do conceito de mímesis, por nós trabalhado em detalhes noutro momento.

Por ora, estamos satisfeitos com esse retorno aos autores do século XVIII. Vejamos a seguir, mais de perto, o texto adorniano a respeito da formação e, no momento que for apropriado, recorreremos novamente a eles.

\section{Adorno e a Semiformação}

A primeira coisa que nos chama a atenção em um dos principais textos de Adorno voltados ao tema da formação é seu título: Teoria da Semiformação (Halbbildung), e não “Teoria da Formação" (Bildung), como se poderia esperar. Com isso a ênfase fica na interrupção, nos impasses do processo de formação e não no próprio processo apenas. Essa ênfase adorniana reflete não um pessimismo, mas um diagnóstico realista da sociedade e uma aposta otimista no poder do pensamento, cuja resistência em aceitar uma fórmula consoladora de formação, prefere indicar sua impossibilidade atual a fim de manter viva sua possibilidade efetiva.

A semiformação, para Adorno, não significa metade de uma formação, ou meio caminho andado para uma: "o entendido e o experimentado medianamente - semi-entendido e semi-experimentado - não constitui o grau elementar da formação e sim seu inimigo mortal” (ADORNO, 1996, p. 402). ${ }^{39}$ A semiformação representa uma crise na formação, é algo em que a formação se degenerou:

A formação cultural agora se converte em uma semiformação socializada, na onipresença do espírito alienado, que segundo sua gênese e seu sentido, não antecede à formação cultural, mas a sucede [...] Símbolo de uma consciência que renunciou à autodeterminação, prende-se, de

39 Uma outra tradução possível para Halbbildung é “pseudoformação” ou “pseudocultura”, tradução muitas vezes criticada no Brasil. Porém, como pudemos constatar em texto escrito em inglês pelo próprio Adorno (1994a), este optou pelo uso do termo pseudo-culture. Assim, a nosso ver, ambas as traduções são justificáveis. 
maneira obstinada, a elementos culturais aprovados [...] Apesar de toda ilustração e de toda informação que se difunde (e até mesmo com sua ajuda) a semiformação passou a ser a forma dominante da consciência atual, o que exige uma teoria que seja abrangente. (ibid., p. 389)

Se a semiformação é símbolo de uma consciência que renunciou à autodeterminação, quer isso dizer que houve um dia uma consciência autodeterminada? O que Adorno argumenta ao longo do texto é que ela já existiu pelo menos enquanto ideal da burguesia. E foi com o objetivo de saber que ideal era esse que recorremos a Kant, Goethe e Schiller.

O conceito tradicional de formação, nos diz Adorno, "se emancipou com a burguesia" (ibid., p. 391). E aqui encontramos um dos momentos mais poderosos da consideração dialética de Adorno a respeito da formação: a burguesia não solapou a formação que os nobres tinham, como uma leitura ingênua do Meister do Goethe poderia indicar; foi a burguesia, na formulação de pensadores como Kant, Goethe e Schiller que ela se emancipou das suas amarras à nobreza. Adorno, herdeiro do marxismo, não quer guilhotinar os burgueses, como Schiller não queria guilhotinar os nobres. Como vimos, não é assim tão simples:

\footnotetext{
Caracteres ou tipos sociais do feudalismo, como o fidalgo e o gentleman, e especialmente a antiga erudição teológica, despiram-se de seu ser tradicional e de suas determinações específicas e emanciparam-se das unidades vitais de que, até então, estava impregnados. A formação tornou-se objeto de reflexão e consciente de si mesma, foi devolvida purificada aos homens. (ibid, p. 391)
}

Ou seja, foi só com os ideais burgueses de uma sociedade livre e igualitária é que se pôde pensar uma formação que mantivesse essa tensão entre espírito e natureza. Não foi justamente esse ideal de formação que vimos em Goethe e Schiller, o "fidalgo", a "nobreza” emancipada?

Sabemos, no entanto, que esses ideais burgueses não se concretizaram, que na realidade a formação burguesa se realizou como privilégio de alguns poucos, os burgueses, à custa da exploração de muitos, o proletariado; que os ideais burgueses de liberdade e igualdade se erigiram em ideologia, e que, portanto, podemos dizer, como Benjamin, que até hoje, no tocante à formação, cada monumento de cultura ainda é um monumento de barbárie.

Apesar disso, porém, podemos dizer, como Adorno, não devemos jogar fora “a criança com a água do banho". No aforismo da Minima Moralia, que recebe este nome, ele diz que "o medo da impotência da teoria fornece o pretexto para se entregar ao todo-podereso pro- 
cesso de produção" e "identificar a cultura unicamente com a mentira é o que há de mais funesto no momento em que aquela está se convertendo efetiva e inteiramente nesta" (id., 1992, p. 37). Ou seja, que o fato dos ideais não terem se cumprido não significa que devemos abandonar os ideais e se submeter ao factual. Isso se aplica no tocante à formação: "É ainda a formação cultural tradicional, mesmo que questionável, o único conceito que serve de antítese à semiformação socializada" (id., 1996, p. 395).

Muito importante na nossa interpretação do texto adorniano é a ênfase que ele dá ao conceito de experiência no processo de formação. Essa ênfase, como veremos ainda em detalhes mais à frente, põe em segundo plano, apesar de não desconsiderar - de maneira alguma - o papel da educação formal na formação. Isso porque, quando as possibilidades de experiência estão barradas, "as condições da produção material dificilmente toleram o tipo de experiência sobre a qual se assentavam os conteúdos formativos tradicionais que se transmitiam" (ibid., p. 394), dificilmente um conteúdo programático formativo, no sentido tradicional, terá resultados. A ênfase na experiência aponta para as condições objetivas da sociedade como cerne do problema e não uma falha pedagógica.

O conceito de experiência (Erfahrung) em Adorno, porém, exige, ao menos, uma rápida consideração sobre o mesmo em Benjamin, de quem Adorno o toma emprestado.$^{4^{\circ}}$ No texto em questão, por exemplo, em outro trecho sobre a experiência, pode-se ler:

A experiência - a continuidade da consciência em que perdura o ainda não existente e em que o exercício e a associação fundamentam uma tradição no indivíduo - fica substituída por um estado informativo pontual, desconectado, intercambiável e efêmero, e que se sabe que ficará borrado no próximo instante por outras informações. (ibid., p. 405)

Encontramos aqui uma clara influência da diferenciação que faz Benjamin (2000 [1939]) entre vivência e experiência (em alemão, Erlebnis e Erfahrung, respectivamente).

Na experiência, o tempo seria vivido como duração (a durée, de Bergson, do Matière et Memoire), isto é, qualitativamente. O momento do encontro, o momento do beijo, o momento

40 Seligmann-Silva (2009) aponta que o conceito de experiência em Benjamin se insere na tradição dos autores românticos alemães Schlegel e Novalis, na cobrança que estes faziam para a expansão desse conceito em Kant (p. 48). 
do olhar de reprovação da mãe, nenhum desses pode ser aprisionado na contagem quantitativa do tempo, em dias, horas, minutos.

A experiência não é fruto da simples atenção consciente, por isso não se pode evocá-la apenas por um ato deliberado da vontade. A experiência, Benjamin busca em Proust, estaria mais ligada a mémoire involontaire, aquela que nos acomete de repente ao tomarmos contato com um objeto que nos transporta a um momento distante, como fazem os bolinhos do tipo madeleine para o protagonista de Em Busca do Tempo Perdido.

A experiência, nos fala Benjamin, está mais próxima à narração do que à informação. Na narração, aquilo que se pretende transmitir está gravado no narrador "como os vestígios das mãos do oleiro no vaso de argila" (ibid., p.107).

Na experiência não é negada a dimensão corporal dos homens, por isso o que é vivido é "incorporado" e pode ser trazido à tona por um cheiro, ${ }^{41}$ uma posição do corpo na cama.

Quando a natureza é negada (pelo homem), ela retorna na forma de dominação (sobre o próprio homem) - esse é o correspondente ao retorno do recalcado de Freud em Adorno e outros autores da Teoria Crítica. Se o narrador de Benjamin traz no seu corpo as marcas do que viveu, como vestígios de mãos na argila, inconscientemente e, por isso, símbolo de natureza não dominada, é porque só assim pode ser transmitido algo da particularidade insubstituível do vivido.

A vivência, ao contrário, é a representação da dominação que vai da atenção à memória. Benjamin dá o exemplo dos jornais. A própria forma como são dispostas as informações nele já impedem que os fatos sejam incorporados à experiência. Os princípios da informação jornalística: "novidade, concisão, inteligibilidade e, sobretudo, falta de conexão entre uma notícia e outra" (ibid., p. 107) não são diferentes daqueles da abstração exacerbada do esclarecimento - anular toda particularidade.

Benjamin recorre a Freud para dizer que a consciência não tem por objetivo reter o vivido e sim proteger contra estímulos excessivos. E acrescenta a isso a descrição de uma metrópole moderna, Londres, por Poe, em O Homem da Multidão, para mostrar como o excesso de

41 "Por isso o cheiro, tanto como percepção quanto como percebido (ambos se identificam no ato), é mais expressivo que os outros sentidos. Ao ver, a gente permanece quem a gente é, ao cheirar, a gente se deixa absorver" (ADORNO; HORKHEIMER, 1985, p. 172). 
estímulos atinge níveis nunca antes alcançados na história, de modo que não é casual a principal maneira de experenciar, no mundo moderno, ser a vivência do choque ou sua evitação.

Trazendo agora esses dois conceitos para o campo da estética, a maneira como Gagnebin (2005a), grande estudiosa, no Brasil, das obras de Benjamin, coloca a diferença entre esses dois conceitos evocará, talvez, no leitor, a relação que pretendemos estabelecer entre experiência (Erfahrung) e vivência (Erlebnis) com o aparecer (Schein) e o ser (Sein), que vimos inicialmente a propósito do Meister, e que ressurgiu nas Cartas:

[...] ao tempo pleno da vie antérieure correspondem a experiência no sentido enfático do termo (Erfahrung), o símbolo na sua harmonia e o valor de culto da arte; ao tempo vazio da modernidade, a experiência vivida individual e isolada (Erlebnis), a dispersão do sentido na alegoria e a desauratização da arte. (p. 150)

Ou seja, a harmonia, um atributo, como vimos, do aparecer, também o é da experiência, e a fragmentação, atributo do ser, também o é da vivência. Além disso, vê-se que entra em jogo na citação mais um conceito de Benjamin, o de aura. Vejamos como o próprio explica o que entende por este - na citação acima representado pela sua face degenerada, a desauratização - e essa relação entre experiência e aparência ganhará mais elementos:

\begin{abstract}
Em suma, o que é a aura? É uma figura singular, composta de elementos espaciais e temporais: a aparição única de uma coisa distante, por mais perto que ela esteja. Observar, em repouso, numa tarde de verão, uma cadeia de montanhas no horizonte, ou um galho, que projeta sua sombra sobre nós, significa respirar a aura dessas montanhas, desse galho. Graças a essa definição, é fácil identificar os fatores sociais específicos que condicionam o declínio atual da aura. Ele deriva de duas circunstâncias, estreitamente ligadas à crescente difusão e intensidade dos movimentos de massas. Fazer as coisas "ficarem mais próximas" é uma preocupação tão apaixonada das massas modernas como sua tendência a superar o caráter único de todos os fatos através da sua reprodutibilidade. Cada dia fica mais irresistível a necessidade de possuir o objeto, de tão perto quanto possível, na imagem, ou antes, na sua cópia, na sua reprodução. (BENJAMIN, 1996a [1935-1936], p. 170, grifo nosso)
\end{abstract}

Será que não podemos dizer que o aparecer do nobre no Meister também não era “a aparição única de uma coisa distante, por mais perto que ela esteja” já que, só para citar um exemplo, o próprio tom de sua voz (do nobre) fazia diferença? Não era apenas o dito que importava no nobre, e sim o "como" era dito. A particularidade insubstituível dessa maneira de aparecer o tornava um outro que devia ser respeitado em sua diferença, como vimos em Schiller. 
Não é a "necessidade de possuir" o objeto semelhante à existência útil do burguês, onde todas as coisas são tomadas pelo seu valor de instrumento e, assim, equivalem?

Note como essas idéias aparecem no texto de Adorno:

[...] a perda da tradição, como efeito do desencantamento do mundo, resultou num estado de carência de imagens e formas, em uma devastação do espírito que se apressa em ser apenas um meio, o que é, de antemão, incompatível com a formação. Nada retém o espírito, então para um contato corporal com as idéias. (ADORNO, 1996, p. 397)

A perda da tradição - aqui em sentido amplo -, podemos ler, no contexto do Meister, como o desprezo do burguês pelos valores da nobreza ("certas formas exteriores positivas", como vimos em Schiller). O aparecer do nobre, no ideal de Goethe, é justamente abundante de imagens e formas, não é mero meio, e é corporal e ideal ao mesmo tempo.

Esse "contato corporal com as idéias" é, a nosso ver, uma das melhores sínteses da concepção de experiência em Adorno e Benjamin, contato esse que, por meio do conceito de mímesis, abordado em maiores detalhes no capítulo seguinte, ficará ainda mais claro, em seu caráter utópico de reconciliação com a natureza.

Uma segunda característica da semiformação - depois da degeneração da experiência, muito embora a esta relacionada - apontada por Adorno que gostaríamos de destacar é a degeneração do próprio conceito, com a sua substituição pelo clichê ou, como encontraremos em outros textos, pela falsa projeção, pelo preconceito:

\footnotetext{
O conceito fica substituído pela subsunção imperativa a quaisquer clichês já prontos, subtraídos à correção dialética, que descobre seu destrutivo poder nos sistemas totalitários. (ibid., p. 406)
}

Se já vimos um pouco, no início, o processo social da fetichização dos conceitos, veremos agora sua face subjetiva. Como diz Adorno, de forma lapidar: "A semiformação é o espírito conquistado pelo caráter de fetiche da mercadoria" (ibid., p. 400).

Vejamos uma passagem da Dialética do Esclarecimento na qual já encontramos a expressão "indivíduo semicultivado", nela pode-se notar tanto a degeneração da experiência quanto o que os autores chamam de "falsa projeção" - uma degeneração do conceito: 
A falsa projeção é o usurpador do reino da liberdade e da cultura; a paranóia é o sintoma do indivíduo semicultivado. Para ele, todas as palavras convertemse num sistema alucinatório, na tentativa de tomar posse pelo espírito de tudo aquilo que sua experiência não alcança, de dar arbitrariamente um sentido ao mundo que torna o homem sem sentido, mas ao mesmo tempo se transformam também na tentativa de difamar o espírito e a experiência de que está excluído e de imputar-lhe a culpa que, na verdade, é da sociedade que o exclui do espírito e da experiência. (ADORNO; HORKHEIMER, 1985, p. 182, grifo nosso)

Se o conceito precisa do ego "bem formado", a semiformação evidentemente produzirá algo diferente do conceito. Adorno e Horkheimer trataram longamente disso na Dialética do Esclarecimento, no ensaio sobre o anti-semitismo. Como veremos no capítulo a respeito da mímesis, nessa obra eles ainda enfatizam o caráter regressivo da mímesis, não o caráter progressivo (e utópico) que assinalamos há pouco.

Para eles, a falsa projeção é uma saída da mímesis (enquanto assimilação com a natureza) que acaba em barbárie:

\begin{abstract}
Só a mimese se torna semelhante ao mundo ambiente, a falsa projeção torna o mundo ambiente semelhante a ela. Se o exterior se torna para a primeira o modelo ao qual o interior se ajusta, o estranho tornando-se o familiar, a segunda transpõe o interior prestes a saltar para o exterior e caracteriza o mais familiar como algo de hostil. Os impulsos que o sujeito não admite como seus e que, no entanto, lhe pertencem são atribuídos ao objeto: a vítima em potencial. (ibid., p. 174)
\end{abstract}

Ou seja, se o indivíduo não se permite experienciar sua relação com o objeto, ele também não será capaz de formar deste uma imagem que lhe faça jus, pois não entrou em real contato com ele. O indivíduo isolado, apenas evitando o choque, ao se deparar com os objetos, pode apenas atribuir a estes características que são próprias a si mesmo, não a eles. A mutilação que ele vive é atribuída ao outro.

"Em certo sentido, perceber é projetar", nos dizem os autores (ibid., p. 175), desde a pré-história animal do homem. Por exemplo, sentir que algo é comestível ou perigoso, "prazer ou desprazer", não é algo próprio ao objeto, mas aos sentidos, projetado no objeto. E todos os desenvolvimentos posteriores da relação dos homens com os objetos no mundo vai ser uma variação dessa projeção.

Aprendendo a distinguir, compelido por motivos econômicos, entre pensamentos e sentimentos próprios e alheios, surge a distinção do exterior e do interior, a possibilidade de distanciamento e identificação, a consciência de si e a consciência moral. (ibid., loc. cit., grifo nosso) 
"Possibilidade", eles dizem, não necessidade. Pois a tendência, presente em nossa sociedade, de predomínio da falsa projeção é justamente uma negação dessa dialética entre distanciamento e identificação, consciência de si e consciência moral, pré-requisitos para uma sociedade livre e igualitária.

\section{Formação e Educação}

É preciso ter cuidado ao ler a obra de Adorno em busca de referências para se pensar a Educação. A partir de nossa leitura e de trabalhos de comentadores, como os de Batista (1997, 2002) e Maar (2003), acreditamos que sua preocupação se dirigiu na maior parte das vezes para o conceito de formação, como visto até aqui, em sentido amplo, e para as condições reais de efetivação desta; e a educação, entendida como educação formal, dada na escola, poucas vezes comparece, a nosso ver, em primeiro plano.

Segundo Batista (1997) a Teoria Crítica, e Adorno, em especial, não nos fornecem um modelo de pedagogia, nem sequer de uma pedagogia "crítica" ou "radical", mas antes, estaria mais próxima a uma sociologia da educação.

Segundo ela, as inúmeras tentativas de concretizar uma revisão da pedagogia a partir da Teoria Crítica não têm se dado sem contradições e acabam, até mesmo, por descaracterizá-la e enfraquecê-la em seu poder crítico - sua maior contribuição, no sentido de propiciar um distanciamento das próprias práticas pedagógicas:

\footnotetext{
O que entendemos, até o momento, [...] é que a missão da escola deve ser a de se subtrair a moldes de pensar e agir e qualquer transformação possível não está no "ampliar", mas no modificar profundamente não só seus procedimentos, mas sobretudo sua finalidade. (p. 7)
}

Batista (2002), em outro trabalho, vai se dedicar mais especificamente a pensar a contribuição da Teoria Crítica, e em especial Adorno, para o ensino da arte. Como não podia ser diferente, não encontrará uma pedagogia da arte:

Os elementos para reflexão sobre arte e educação a partir da Teoria Crítica podem ser traduzidos na atitude filosófica de sempre confrontar arte, sociedade e história, considerando a relação de imanência entre elas. (p. 229) 
Novamente comparecerá uma contribuição crítica, que prescreve a reflexão antes que uma prática pedagógica. Já abordamos, no capítulo sobre o conceito de emancipação, a posição de Adorno com respeito à relação teoria/práxis; relembrando: de que a teoria já é práxis. Isso não significa, porém, que Adorno não tenha asserções positivas, até mesmo propostas pedagógicas, em relação à educação. Elas apenas não aparecem enquanto modelo pedagógico estruturado.

Vimos no início, com Bolle (1997), que a idéia clássica de formação nasceu justamente como algo que ia além da educação. Em Adorno não é diferente, no decorrer de Teoria da Semiformação, por exemplo, Adorno, por diversos momentos, pontua a distância entre formação e educação. Contudo não opta por uma dicotomia absoluta entre as duas:

\begin{abstract}
O que se manifesta como crise da formação cultural não é um simples objeto da pedagogia, que teria que se ocupar diretamente desse fato, mas também não pode se restringir a uma sociologia que apenas justaponha conhecimentos a respeito da formação. Os sintomas de colapso da formação cultural que se fazem observar por toda parte, mesmo no estrato das pessoas cultas, não se esgotam com as insuficiências do sistema e dos métodos da educação, sob a crítica de sucessivas gerações. Reformas pedagógicas isoladas, embora indispensáveis, não trazem contribuições substanciais. (ADORNO, 1996, p. 388)
\end{abstract}

Note que ao mesmo tempo em que Adorno nega a identidade entre formação e educação, ele não nega o valor da pedagogia, pelo contrário, ela é “indispensável”. Mas como Schiller, Adorno sabe que a mera submissão do homem a preceitos disciplinatórios é uma violência contra a própria humanidade. Ele continua:

\footnotetext{
Poderiam [as reformas pedagógicas isoladas] até, em certas ocasiões, reforçar a crise, porque abrandam as necessárias exigências a serem feitas aos que devem ser educados e porque revelam uma inocente despreocupação diante do poder que a realidade extrapedagógica exerce sobre eles. (ibid., loc. cit.)
}

Em outro trecho do mesmo texto encontramos diretamente a idéia de desumanização como perpetuada pela pedagogia, quando isolada:

\footnotetext{
A desumanização implantada pelo processo capitalista de produção negou aos trabalhadores todos os pressupostos para a formação e, acima de tudo, o ócio. As tentativas pedagógicas de remediar a situação transformaramse em caricaturas. Toda a chamada "educação popular" - a escolha dessa expressão demandou muito cuidado - nutriu-se da ilusão de que a formação, por si mesmo e isolada, poderia revogar a exclusão do proletariado, que sabemos ser uma realidade socialmente constituída. (ibid., p. 393)
} 
Nos textos reunidos, no Brasil, sob o título Educação e Emancipação (2003a), muitos deles transcrições de palestras e conferências radiofônicas, encontramos uma concepção de educação formal, em Adorno, da mesma forma, pouco otimista ${ }^{42}$ em relação ao poder desta na formação. A educação formal está muito limitada em seu poder porque, segundo a leitura adorniana de Freud, os elementos essenciais para a formação do indivíduo se dão logo na primeira infância e estão subordinados à sociedade como um todo, em primeiro lugar, e à família, em segundo. A educação formal, fora a dirigida à primeira infância, teria um papel mais de esclarecimento geral que, apesar de importante, não mudaria de forma significativa os padrões de personalidade já delineados. Por outro lado, seguindo o pensamento de Adorno, ter consciência das limitações da educação formal é tarefa necessária para atribuirmos força a esta onde esta força pode ter. Vejamos em mais detalhes.

Se compararmos trechos de Filosofia e os Professores (2003g [1963]) com os de Educação após Auschwitz (2003b [1967]), integrantes dessa compilação, encontraremos uma amostra do que dissemos acima. No primeiro texto, no qual Adorno fala, poderíamos dizer, sobre educação de adultos, ao tratar dos problemas na formação de professores, ele se mostra bem pessimista em relação ao poder da educação, já localizando, nesse texto, a mudança possível na infância. No segundo texto, por sua vez, ao falar de educação de forma geral, ele se mostra mais otimista, novamente, só no que tange à educação nesse primeiro período da vida. Soma-se a isso o fato de que, muitas vezes, quando Adorno fala em educação infantil, não fica claro se ele está falando da educação formal ou daquela dada pela família.

No primeiro texto, encontramos:

A formação cultural é justamente aquilo para o que não existem à disposição hábitos adequados; ela só pode ser adquirida mediante esforço espontâneo e interesse, não pode ser garantida simplesmente por meio da freqüência de cursos, e de qualquer modo estes seriam do tipo "cultura geral". Na verdade, ela nem ao menos corresponde ao esforço, mas sim à disposição aberta, à capacidade de se abrir a elementos do espírito, apropriando-os de modo produtivo na consciência, em vez de se ocupar com os mesmos unicamente para aprender, conforme prescreve um clichê insuportável. (ADORNO, 2003g, p. 64)

42 Lembremos mais uma vez que o aparente pessimismo de Adorno é seu otimismo; que justamente por não aceitar soluções fáceis, mera acomodação, Adorno mostra acreditar fielmente na possibilidade efetiva de transformação. 
Ou seja, seguindo estritamente esse texto, poderíamos dizer que para Adorno a educação formal tem quase nenhum poder sobre a formação, e que a formação está ligada a fatores subjetivos que fogem à pedagogia, como a disposição e o interesse (em Adorno, entendidos como produzidos socialmente, e não no sentido tacanho de certo psicologismo). A educação infantil já comparece nesse texto, mas apenas para mostrar a inadequação da educação do adulto:

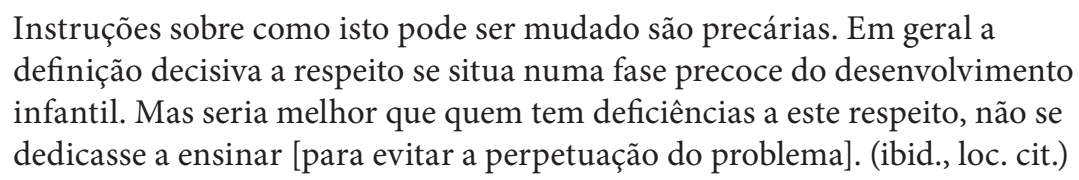

Isto é, o problema da formação se dá na infância, depois disso é tão irremediável que melhor seria se alguém semiformado não se dedicasse a formar. É bem forte essa afirmação de Adorno, e não deve ser desconsiderada. Porém não acreditamos que ela seja uma prescrição de afastamento dos professores semiformados de sua profissão - talvez não sobrasse um, talvez não houvesse mais habilitados. E sim, Adorno aponta, por meio desse exagero, ${ }^{43}$ para a natureza temporal do problema. A formação é um problema em que o tempo é contado em gerações. Até nisso, a nosso ver, Adorno foi antecipado por Schiller:

\footnotetext{
O caráter do tempo, portanto deve primeiramente reerguer-se de sua funda degradação, furtar-se à cega violência da natureza, por um lado, e por outro, regressar à sua simplicidade, verdade e plenitude - trabalho para mais de um século. Entrementes, concedo com prazer, várias tentativas isoladas podem ser bem sucedidas; a totalidade, entretanto, não se verá melhor por isso, e a contradição no comportamento irá sempre depor contra a unidade dos princípios. (SCHILLER, 2009a, p. 59)
}

Em ambos autores, a formação de poucos num mundo onde a maioria é semiformada é até possível, mas nunca se dará sem contradições. Não nos enganemos com o "concedo com prazer" ${ }^{44}$ que o texto de Schiller, assim como suas cartas a Goethe, a respeito do Meister,

Como já visto em nota anterior, segundo Adorno (1992), o exagero é uma característica importante do pensamento para alçá-lo além do mero factual (p. 110). Exagero que, a nosso ver, não é mera figura de retórica, mas uma marca da história, na teoria, quando o autor se permite sentir "tanto medo quanto esta realidade exige" (ADORNO, 2003b, p. 129). 
mostram como sua preocupação é social; que a saída individual é enganosa. Por exemplo, numa carta datada a 8 de julho de 1796, ele diz:

\begin{abstract}
Se eu tivesse de explicar com duras palavras o objetivo o qual Wilhelm finalmente alcança depois de uma longa série de deslizes, então diria: "saindo de um ideal vazio e indeterminado, ele entra numa vida determinada e ativa, mas sem perder com isso a força idealizadora" [...] ele passa do ideal ao real, de uma vaga ambição à ação e ao conhecimento verdadeiro, mesmo sem de fato perder aquilo que era real no primeiro estado ambicionado; como alcança a determinação sem perder a bonita determinabilidade que aprende a limitar [...] (GOETHE; SCHILLER, 2010, p. 93)
\end{abstract}

E um pouco mais a frente, depois desse elogio, Schiller cobra uma maior coerência das outras personagens do romance com o conceito vivido pelo herói. Isto é, para Schiller faltava realçar ainda mais o caráter coletivo necessário dessa passagem ao real.

Já Adorno não usa meias palavras; ele é claro, a formação conseguida de forma isolada, numa sociedade semiformada, é privilégio em seu contexto culposo (ou, em outras palavras, cultura como documento de barbárie):

\begin{abstract}
A formação esquiva-se do autodidatismo, é de árdua conquista pelos próprios punhos e, se adquirida, tende à má posse. Mas, justamente, porque escapa da vontade, está envolvida no culpável contexto do privilégio. Apenas não necessitam adquiri-la, nem possuí-la, aqueles que, a todos os títulos, já a possuem. (ADORNO, 1996, p. 399) (5 $^{4}$
\end{abstract}

Com isso em mente, voltemos à comparação que nos havíamos proposto, entre o Filosofia e os Professores e o Educação após Auschwitz. Se do primeiro destacamos o pessimismo em relação à educação do adulto e à dimensão temporal do problema; no segundo o que salta aos olhos é o otimismo a respeito do que pode ser feito, ainda que limitado, agora - afinal, é necessário!

45 Interessante nesse sentido é ver o caráter contraditório que Adorno atribui àqueles que conseguem atualmente ainda ter uma escuta estrutural da música - e não atomística. Em Introduction to the Sociology of Music (1976 [1962]), ele nos diz que um dos dois grupos que ainda consegue ter essa escuta estrutural está "mais ou menos limitado ao círculo de músicos profissionais" (o outro seria o raro grupo que “entende música da mesma maneira que nós entendemos nossa própria língua muito embora praticamente ou completamente ignorantes de sua gramática e sintaxe"). Segundo ele, querer que todas as pessoas tenham a mesma escuta que os experts seria não apenas "incompatível com sua natureza, com sua situação, e com o estado da educação musical não profissional, mas com a própria liberdade individual” (p. 5, tradução nossa). Em outras palavras, uma educação na atual condição da nossa sociedade que quisesse impor a formação à força é incompatível com a própria idéia de liberdade contida no ideal de formação. 
Nele, como já abordamos indiretamente em momento anterior, Adorno argumenta que, depois de Auschwitz, o absurdo da barbárie, a exigência primeira que se faz à educação é que "Auschwitz não se repita", isto é, que pensemos em como o desenvolvimento da civilização conseguiu culminar nessa extrema barbárie e pensemos também naquilo que a educação pode fazer para impedir a formação de indivíduos tão heterônomos que podiam seguir qualquer ordem, inclusive a do genocídio.

A educação ganha importância para ele devido ser "extremamente limitada a possibilidade de mudar os pressupostos objetivos, isto é, sociais e políticos que geram tais acontecimentos", o que faz com que "as tentativas de se contrapor à repetição de Auschwitz" (ADORNO, 2003b, p. 121) sejam impelidas para o lado subjetivo - como também já tratamos brevemente a propósito do conceito de emancipação. Em outras palavras, as asserções essenciais do primeiro texto se mantêm: se a sociedade em suas bases profundas fosse modificada, a escola por si só já estaria incluída nessa transformação sem que fosse necessária qualquer intenção especialmente dirigida nesse sentido. Porém, agora, Adorno está preocupado em pensar naquilo que pode ser feito já; e entre essas "tentativas de mudança subjetiva" ele elenca, em primeiro lugar, a educação infantil, e, em segundo, o esclarecimento geral. Notemos, nessa concepção, a limitação e a importância da educação para Adorno.

Quanto à educação infantil, ele diz:

[...] conforme os ensinamentos da psicologia profunda, todo caráter, inclusive daqueles que mais tarde praticam crimes, forma-se na primeira infância, a educação que tem por objetivo evitar a repetição precisa se concentrar na primeira infância. (ibid., p. 122)

O esclarecimento geral, outra possibilidade da educação, não teria tanta força, mas não seria, por outro lado, desprezível:

\footnotetext{
Mesmo que o esclarecimento racional não dissolva diretamente os mecanismos inconscientes - conforme ensina o conhecimento preciso da psicologia -, ele ao menos fortalece na pré-consciência determinadas instâncias de resistência, ajudando a criar um clima desfavorável ao extremismo. (ibid., p. 136)
}

Ou seja, segundo a concepção de psicologia em Adorno, grandes mudanças, a nível inconsciente, não seriam possíveis pela via pedagógica, se considerarmos como o papel da pe- 
dagogia o esclarecimento racional. Porém, mudanças menores, a nível pré-consciente, já teriam algum poder.

Ambos os textos citados, assim como os outros da compilação Educação e Emancipação, transcrições de palestras e debates, foram publicados na década de 6o. Porém, sua concepção de psicologia profunda, estrutura de personalidade e correspondente importância da educação infantil já possui uma formulação no começo da década de 40, no importante trabalho do qual Adorno participou, A Personalidade Autoritária (1965 [194-]):

As influências mais importantes sobre o desenvolvimento da personalidade se
apresentam no decorrer da educação da criança dentro do círculo familiar. O que
ocorre ali depende em grande medida de fatores econômicos e sociais. Não se
trata unicamente de que a família proceda, na educação de seus filhos, de acordo
com os costumes dos grupos sociais, étnicos e religiosos aos quais pertencem, mas
também se deve ao fato de que os elementos econômicos crus afetam diretamente a
conduta dos pais para com seus filhos. Isso significa que as grandes mudanças nas
condições e nas instituições sociais têm ação direta sobre os tipos de personalidade
que se formam dentro de uma sociedade. (ADORNo et al, 1965, p. 31, tradução nossa)

Ou seja, fica claro que, para Adorno, a formação se dá essencialmente pela família, enquanto mediação entre o indivíduo e a sociedade.

Na conclusão do trabalho, os autores, dentre eles Adorno, descartam a possibilidade de que essa mudança subjetiva se dê pela via terapêutica ${ }^{46}$ e já apontam para a educação infantil como a possibilidade mais promissora:

Ao se observar a rigidez do adulto etnocêntrico, se nos impõe perguntar se, ao se exercer a devida influência em um período mais precoce da vida do indivíduo, não haveria melhores perspectivas de se conseguir que a estrutura de sua personalidade fosse mais sã. Além disso, visto que quanto antes se exerce esta influência, mais profundos são seus efeitos, resultaria imperativo concentrar-se na educação infantil. (ibid., loc. cit., tradução nossa)

Os autores, porém, não falam em educação formal. A educação infantil a qual eles se referem diretamente no texto, ao que tudo indica, é a educação dada pela família. Porém,

46 "Se pensarmos no tempo e no trabalho árduo que esta tarefa requer, e que para realizá-la se contaria apenas com um pequeníssimo número de terapeutas, e se lembrarmos que muitos dos principais traços do indivíduo etnocêntrico são precisamente aqueles mesmo sintomas que, na prática médica comum, se consideram quase incuráveis, vê-se de imediato que a contribuição direta da psicoterapia individual só pode ser insignificante" (ibid., p. 906, tradução nossa). 
seguindo essa linha de raciocínio, poder-se-ia extrapolar, talvez, pensando que a educação teria um papel mais importante quanto mais prematura fosse a entrada da criança na escola.

A diferença essencial, para nossos interesses, entre o estudo da personalidade autoritária e os textos de 60 está no enfoque. No primeiro Adorno está interessado em diagnosticar uma possível tendência fascista latente na personalidade de alguns indivíduos mesmo em países democráticos. Já nos textos da década de 60, por outro lado, a preocupação direta é saber o que a educação pode fazer para evitar o retorno do fascismo, já que a possibilidade de mudança nas condições objetivas parece paralisada. ${ }^{47}$

No primeiro texto, Adorno já tem em mente que uma das formas de se evitar o fascismo é a promoção da autonomia:

É de se supor que o conhecimento da natureza e do grau do potencial antidemocrático servirão para orientar um plano de ação democrática. Este não deve limitar-se a propor procedimentos que tendam a conduzir o povo de modo a que este se comporte mais democraticamente, também há de dedicar-se a fomentar as formas de autoconsciência e autodeterminação que impedem todo tipo de manipulação. (ibid., p. 35, tradução nossa)

47 Muitos estudiosos criticam as posições de Adorno sobre a educação por estarem elas comprometidas demais com o perigo do fascismo, que isso as tornariam "datadas", isto é, limitadas ao seu tempo. Porém, uma leitura mais cuidadosa de Adorno, a nosso ver, mostra como elas são realmente "datadas", mas não no sentido limitador. Quem ler os trabalhos citados acima poderá perceber facilmente que a preocupação "abstrata" de Adorno é com os conceitos de autonomia e emancipação. Uma das características mais fascinantes dos seus textos, porém, é que cada um deles é um exemplo de aplicação da sua teoria, cada um dos seus textos é uma realização da sua concepção de união dialética entre teoria e prática, forma e conteúdo. Para alguém que, como vimos, é contrário à tendência de excessiva abstração não basta falar de autonomia e emancipação abstratamente. Como já vimos um pouco a propósito da alegoria em Benjamin, e ainda veremos mais detalhadamente em nossa análise da Teoria Estética, de Adorno, as palavras guardam a história. E mesmo as palavras "limpas" de subjetividade da linguagem científica e/ou filosófica guardam a história da dominação que suprime a subjetividade. O que Adorno pretende, ao falar de autonomia, falando do fascismo, é não negar o caráter histórico da linguagem. Falar de autonomia e emancipação depois do nazismo, sem falar do nazismo, é recalcar o passado. "Em seu Estado de não-liberdade, Hitler impôs aos homens um novo imperativo categórico: instaurai o vosso pensamento e a vossa ação de tal modo que Auschwitz não se repita, de tal modo que nada desse gênero aconteça. Esse imperativo é tão refratário à sua fundamentação quanto outrora o dado do imperativo kantiano" (ADORNO, 2009, p. 302). Gagnebin (2009a) ressalta, como achamos importante fazê-lo aqui, que esse imperativo categórico nos foi imposto por uma "figura histórica precisa" e é "manifestação da crueldade e da contingência históricas” (p. 75). 
Porém, nesse trabalho ele não irá falar mais detalhadamente sobre esse plano de ação democrática, ou sobre como fomentar formas de autoconsciência e autodeterminação.

Nos textos de 60 ele fala: é por meio da educação. Mas é importante notar que a educação já entra em função de dois fracassos: o da sociedade, em criar condições para a formação sem precisar de instrumentos especiais para isso (como a própria educação), e o da família, que enquanto conjunto relativamente independente da sociedade poderia ter garantido a formação a despeito do clima social desfavorável..$^{8}$

O conceito de formação enquanto tensão entre natureza e espírito, que Adorno resgatou da tradição, nos textos de 60 aparecem em termos de adaptação e emancipação. Isto é, a formação, como algo oscilando entre ajustar o homem à vida em sociedade e a autoconsciência e autodeterminação de que falamos acima:

A educação ${ }^{49}$ seria impotente e ideológica se ignorasse o objetivo de adaptação e não preparasse os homens para se orientarem no mundo. Porém ela seria igualmente questionável se ficasse nisto, produzindo nada além de well adjusted people, pessoas bem ajustadas [...] (ADORNO, 2003d [1967], p. 143)

No capítulo anterior vimos também que, para Adorno, o conceito de formação se emancipou junto com a burguesia, ou seja, que este pode se dar apenas em meio aos ideais de liberdade e igualdade - desenvolvidos graças à idéia de livre mercado. Nos textos de 60, Adorno apenas confirma essa natureza histórica da formação e nos indica qual foi o caminho trilhado por ela até aqui:

A importância da educação em relação à realidade muda historicamente. Mas se ocorre o que eu assinalei há pouco - que a realidade se tornou tão poderosa que se impõe desde o início aos homens -, de forma que este processo de adaptação seria realizado hoje de um modo antes automático. A educação por meio da família, na medida em que é consciente, por meio da escola, da universidade teria neste momento de conformismo onipresente muito mais a tarefa de fortalecer a resistência do que de fortalecer a adaptação. (ibid., p. 144)

48 “Com a família desfez-se, enquanto o sistema subsiste, não somente a mais eficaz instituição burguesa, mas a resistência, que decerto reprimia o indivíduo, mas também o reforçava, se é que não o produzia pura e simplesmente" (ADORNO, 1992, p. 17).

49 Lembremos que, no pensamento de Adorno, muitas vezes o termo educação se refere à formação de modo geral antes que à educação formal apenas, como acreditamos ser o caso aqui. 
Assim, esse trecho deixa bem claro quatro pontos que pretendíamos demonstrar: primeiro, que no pensamento de Adorno tanto a formação quanto a educação são historicamente determinadas; segundo, que o papel cada vez mais importante da educação formal se dá em face da forma desmesurada em que a (semi)formação tende para a adaptação em nossa sociedade; terceiro, que a (semi)formação dada pela família, de forma inconsciente, fracassou em resistir a essa adaptação desmesurada; e quarto, que a educação familiar consciente e a educação formal nas escolas ganham importância justamente graças ao fracasso da formação nas duas instâncias anteriores.

Até aqui reconhecemos o limite de forma mais negativa que positiva. Isto é, vimos que a educação formal não vai mudar, por si só e automaticamente, a maneira como a formação se dá em nossa sociedade, nem reverter os efeitos deletérios da semiformação já instituída. Contudo, o que seria então aquilo que a educação formal pode fazer na educação infantil e enquanto esclarecimento geral? Se pode fazer algo, o que é?

Em uma palavra seria esclarecer, no sentido forte do termo. Não no sentido desgastado e submetido aos ditames da razão técnica, que significa, grosso modo, dominação, mas sim naquele sentido para onde caminha toda a obra de Adorno e que culmina na Teoria Estética: esclarecimento como reconciliação, ou, ao menos, e ao mesmo tempo, mais importante em nossos dias, sua utopia.

Se o esclarecimento não pode, nem a duras penas, desfazer, no tempo de uma geração, a semiformação socializada, já que o sujeito semiformado dificilmente mudará da "água para o vinho", ele pode, por outro lado, naquilo que chamamos aqui de esclarecimento geral, instituir, como num passe de mágica, com a mesma facilidade de um "imagine", ao menos por um instante, ainda que o instante mesmo da sua enunciação, a utopia da reconciliação, mesmo na mente (e corpo) mais dominadora (e dominada), e a imagem da verdadeira formação aparecerá, nesse instante, no horizonte. Enquanto isso, na educação infantil, a utopia da reconciliação, que envolve a dor dos adultos, pais e professores, por saberem que a utopia é a imagem da falta que não esconde a ferida, essa utopia, pela sua existência mesma, abre as portas para um além de si.

No texto Educação - Para Quê?, esse esclarecimento do qual falamos há pouco aparece sob o nome de "produção de uma consciência verdadeira". Nem modelagem, nem transmissão 
de conhecimentos (ADORNO, 2003d, p. 141). Se é na primeira infância que, para ele, o indivíduo pode ser influenciado, poder-se-ia pensar em modelagem, em formas de tornar, a partir de fora, a criança num indivíduo emancipado. Porém, a emancipação não se pode dar a partir de fora, nem por meio da aquisição de conhecimentos de forma abstrata. A maneira possível de produção de uma consciência verdadeira é por meio da promoção da verdadeira experiência (Erfahrung), a mesma sobre a qual tratamos no capítulo anterior, em oposição à mera vivência (Erlebnis).

Maar (2003) destaca dois momentos do processo vinculados ao "conteúdo de verdade da experiência, isto é, referentes à experiência formativa num sentido emancipatório tal como Adorno a procuraria apreender" (p.24): o momento materialista e o momento histórico. O primeiro seria aquele em que se procura recuperar a experiência do concreto sensível, ligado à mímesis, e o segundo seria aquele em que a memória do processo se faz presente, em que pode haver elaboração do passado, apreensão do presente e transformação do futuro.

Essa separação, porém, é artificial, é só pode ser feita com reservas. Como veremos na análise da Teoria Estética, seguindo o caminho já aberto até aqui, o concreto sensível guarda a história, ambos são intrínsecos. No concreto sensível estão inscritas tanto a dor do passado quanto a prisão do presente e a utopia do futuro.

A arte, a verdadeira arte, para Adorno, por meio da mímesis, como ainda veremos mais detidamente, é o modelo de conhecimento que vai do concreto sensível ao universal possível, e é por isso que escolhemos investigar o ensino da arte, e não qualquer ensino, para se pensar a formação do indivíduo.

O ensino da arte, acreditamos, é a ponta de lança de um projeto de transformação mais amplo. E pretendemos reforçar isso, a partir do pensamento de Adorno. 


\section{O Conceito de Arte}




\section{Nota sobre a Teoria Estética}

A Teoria Estética é um livro editado postumamente, publicado em 1970 pelas mãos de Gretel, esposa de Adorno, e de Rolf Tiedemann; tendo o autor falecido no ano anterior.

Sem o domínio do idioma original, o alemão, nos basearemos principalmente em duas edições, uma delas em português - Edições 70, Lisboa, 2006 - e outra em inglês - University of Minnesota Press, Minneapolis, 1997.

Segundo nota dos editores, na edição americana o texto está disposto exatamente como na publicação original, quase um único e contínuo bloco, não fosse o discreto espaçamento que subdivide o texto, se é que se pode dizer assim, em doze partes ou fragmentos. Essas doze partes são nomeadas, no sumário, com palavras-chave, de modo muito semelhante a uma divisão em capítulos, e para cada uma dessas partes constam tantas outras palavras-chaves referentes ao conteúdo de cada subdivisão. Tal nomeação é uma adição feita pelos próprios editores, baseados em palavras-chave encontradas nas páginas manuscritas de Adorno.

A edição portuguesa, por outro lado, segue, segundo o tradutor, a separação de uma edição francesa, que "por comodidade", apresenta um número maior de separações que doze, mas menor que os "sub-capítulos" da versão americana. Nessa edição também não se encontram as palavras-chave da outra.

Outra diferença importante é que a edição americana inclui uma seção de fragmentos os quais Adorno ainda não havia inserido no corpo da obra, organizada sob o nome 
de Paralipomena, um excurso chamado Theories on the Origin of Art, e uma introdução que Adorno teria abandonado por outra que não chegou a ser feita, a Draft Introduction. Tais seções não constam na versão portuguesa de 2006; porém, foram publicadas em separado sob o título Experiência e Criação Artística (2003), também pela Edições 70.

Segundo Jimenez (1977), Adorno já havia adotado uma divisão por capítulos, abandonada por ele em outubro de 1968, e, na revisão final, que faria em 1970, pretendia apenas “depurar o estilo", isto é, dificilmente a retomaria. Desse modo, seguir pela divisão da edição americana, poder-se-ia pensar, iria contra as intenções do autor. Por outro lado, porém, resolvemos nos guiar por tal por acreditarmos que os trechos reunidos sob cada parte guardam um nexo importante de ser considerado.

Assim, ao mesmo tempo em que seguimos a edição portuguesa, cotejamos com a edição americana e nos baseamos na divisão desta para destacar em nossa análise, em especial, os dois primeiros fragmentos: Arte, sociedade e estética e Situação, o que abrange, respectivamente, as páginas 11-27 e 27-60 da edição portuguesa; assim como parte do sétimo e do décimo fragmentos: Caráter enigmático, conteúdo de verdade, metafísica e Em direção a uma teoria da obra de arte, páginas 138-157 e 199-225 da edição portuguesa, respectivamente. Não nos privamos, porém, de recorrer a outros fragmentos além dos citados.

Preferimos chamar cada uma das diferentes partes de fragmentos, tendo em vista o estilo característico da escrita adorniana e seu propósito nessa obra. A Teoria Estética, como dizem com unanimidade seus comentadores, foi escrita num estilo paratático, que não parte de um princípio de subordinação, mas de coordenação de suas diversas partes. Isto é, não foi pensada de forma que cada parte fosse uma seqüência lógica da seguinte, mas que as diversas partes fossem interdependentes entre si.

\section{Arte, Sociedade e Sujeito}

Para abordar o conceito de arte em Adorno escolhemos, num primeiro momento, ao invés de nos aventurar na tarefa hercúlea que seria um apanhado geral pelo transcorrer de sua obra, nos aprofundar em apenas uma, a última, onde encontramos, a nosso ver, sua der- 
radeira formulação. Optamos também por recorrer a outros textos, tanto do próprio Adorno quanto da parceria dele com Horkheimer - ou textos de Benjamin e Marcuse, assim como seus comentadores, sempre a partir de uma evocação em nós produzida por esse texto base, cientes da limitação que isso acarreta. Neste capítulo e no próximo nos ateremos principalmente à primeira e à segunda parte/fragmento da Teoria Estética, quase parágrafo a parágrafo, devido ao objetivo mesmo, nelas, de delimitação conceitual, por parte de Adorno. Em seguida, faremos um apanhado mais geral em outras partes da obra, a propósito de outros conceitos importantes para nossos objetivos que ganharão evidência: os de mímesis, construção, expressão, conteúdo de verdade, escrita e historiografia inconsciente.

Assim, em acordo com as palavras-chaves que encabeçam o primeiro fragmento da Teoria Estética - Arte, Sociedade, Estética - podemos dizer que nele encontramos, em linhas gerais, o conceito adorniano de arte, sua relação com a sociedade e os primeiros posicionamentos de uma Estética - os quais veremos, estão intrinsecamente ligados a uma concepção de sujeito.

Para nossos interesses subdividimos esse fragmento em três partes (não coincidentes com os três assuntos apontados acima, mesmo porque estes se encontram entrelaçados no texto).

Em primeiro lugar, analisaremos apenas o $\$ 1$, abertura da obra, ao qual daremos especial atenção tendo em vista se encontrar nele sintetizado, a nosso ver, tanto o diagnóstico quanto o projeto de Adorno sobre o lugar da arte em nossa sociedade.

A segunda parte abrange os $\$ 2-4$, nos quais Adorno apresenta formalmente um conceito negativo de arte - e uma definição possível -, que pretende não perder a tensão desta com a sociedade e com a história; o que tentaremos expor brevemente.

E uma terceira, dos $\$_{5}-8$, em que Adorno parte de e tenta superar duas vertentes importantes da Estética no pensamento ocidental: a kantiana e a freudiana; nessa parte nos deteremos principalmente em como, para ele, o conceito de arte é indissociável do conceito de sujeito.

Assim, na primeira página, no primeiro parágrafo, a primeira frase no diz:

Tornou-se manifesto que tudo o que diz respeito à arte deixou de ser evidente, tanto em si mesma como na sua relação ao todo, e até mesmo o seu direito à existência. (ADORNO, 2006, p. 11) 
Adorno já mina, portanto, de antemão, qualquer possibilidade de uma definição ontológica e apriorística de arte, se até mesmo seu direito à existência deixou de ser evidente e precisará ser justificado; ao mesmo tempo em que marca, logo de início, como seu pensamento não fetichiza o conceito de arte, considerando-a como um campo isolado e imutável, mas sim em sua relação com a história e com o todo - que para a Teoria Crítica, como se sabe, não é de forma alguma um todo idealista, mas sim se refere à sociedade, seu modo de produção e suas contradições.

O primeiro parágrafo inteiro é de um poder de síntese notável. Nele encontramos condensadas duas das principais teses desenvolvidas por ele em conjunto com Horkheimer, na Dialética do Esclarecimento, adaptadas às exigências da tarefa que se propõe então: a apresentação de uma teoria estética.

Em primeiro lugar encontramos a tese central de que o mito já era esclarecimento e que este acaba por se reverter em mitologia; só que agora nos seguintes termos:

\footnotetext{
A perda do que se poderia fazer de modo não reflectido ou sem problemas não é compensada pela infinidade manifesta do que se tornou possível e que se propõe à reflexão. $\mathrm{O}$ alargamento das possibilidades revelase em muitas dimensões como estreitamento. (ibid., p. 11)
}

Ora, progresso que em muitos sentidos significa regressão - em especial, no caso, a passagem de um estado não refletido para um refletido em que o ganho de liberdade, por um lado, é acompanhado de sua perda, por outro - é o movimento dialético do próprio esclarecimento, tal como ele e Horkheimer formularam já também no primeiro parágrafo da obra seminal, já citado anteriormente:

\footnotetext{
No sentido mais amplo do progresso do pensamento, o esclarecimento tem perseguido sempre o objetivo de livrar os homens do medo e investi-los na posição de senhores. Mas a terra totalmente esclarecida resplandece sob o signo de uma calamidade triunfal. (ADORNO; HORKHEIMER, 1985, p. 19)
}

Essa calamidade triunfal, como já vimos também a propósito dos conceitos de emancipação e formação, é o domínio ostensivo do homem pelo próprio homem, num julgo tão pior ou maior que o da própria natureza ao qual estávamos subjugados no mito; domínio esse que terá seu representante máximo - e de máximo horror - no extermínio fascista. 
A esta tese, soma-se outra, que pode ser encontrada na própria Dialética do Esclarecimento, a respeito do estatuto da autonomia da arte e seu lugar na dialética entre mito e esclarecimento; lugar este de participação tanto na magia quanto no desencantamento, sem, no entanto, render-se a qualquer um deles. Vejamos, desta vez, como essa tese aparece na Dialética do Esclarecimento, para depois sentirmos seu eco na Teoria Estética:

\begin{abstract}
A obra de arte ainda tem em comum com a magia o fato de estabelecer um domínio próprio, fechado em si mesmo e arrebatado ao contexto da vida profana. Neste domínio imperam leis particulares. Assim como a primeira coisa que o feiticeiro fazia em sua cerimônia era delimitar em face do mundo ambiente o lugar onde as forças sagradas deviam atuar, assim, também, com cada obra de arte, seu círculo fechado se destaca do real. É exatamente a renúncia a agir, pela qual a arte se separa da simpatia mágica, que fixa ainda mais profundamente a herança mágica. Esta renúncia coloca a imagem pura em oposição à realidade mesma, cujos elementos ela supera retendo-os (aufhebt) dentro de si. Pertence ao sentido da obra de arte, da aparência estética, ser aquilo em que se converteu, na magia do primitivo, o novo e terrível: a manifestação do todo no particular. (ibid., p. 32)
\end{abstract}

Tanto nesse trecho quanto no que veremos da Teoria Estética, o nascimento da arte é apontado como vindo da magia e herdando dela, em sua constituição, o caráter de "domínio próprio", "fechado em si mesmo", com "leis particulares" - todas elas expressões que designam autonomia frente ao real. Mas note também que não é uma autonomia absoluta, a arte "se destaca" do real, mas partiu dele, supera os elementos da realidade, mas os retém dentro de si. Enquanto imagem, não precisa ser mero reflexo da realidade (como pretende ser o esclarecimento); pelo contrário, pode se opor a ela, desde que essa contraposição ao todo seja sempre, ao mesmo tempo, manifestação do mesmo. A diferença, para com o trecho a seguir da Teoria Estética, é que este já apresenta a conseqüência lógica da junção da primeira tese com a segunda, ou seja, se a relação entre arte e sociedade, particular e todo, é de autonomia relativa ( $2^{\mathrm{a}}$ Tese), em uma sociedade em que o progresso culmina numa regressão sem precedentes, na dominação levada ao extremo mesmo do extermínio ( $1^{\text {a }}$ Tese), a arte deverá, nessa sociedade, conter ao menos uma marca da possibilidade desse extermínio - e que inclui, portanto, já que produto humano, também a possibilidade do seu próprio. Destacamos: 
Com efeito, a liberdade absoluta na arte, que é sempre a liberdade num domínio particular, entra em contradição com o estado perene de nãoliberdade do todo. O lugar da arte tornou-se nele incerto. A autonomia que ela adquiriu, após se ter desembaraçado da função cultual e dos seus duplicados, vivia da idéia de humanidade. Foi abalada à medida que a sociedade se tornava menos humana. (ADORNO, 2006, p. 11, grifo nosso)

Afora essas duas teses da Dialética do Esclarecimento, encontramos também, nesse primeiro parágrafo, o eco de outra similar, um pouco anterior, muito conhecida entre nós pelo desenvolvimento que lhe deu Marcuse em um artigo para a Revista do Instituto de Pesquisa Social, publicado em $1937^{50}$ : a tese a respeito do caráter afirmativo da cultura.

Em linhas gerais, Marcuse (1997) parte de uma análise da separação entre o útil e o belo (de certo modo entre o "ser" e o "aparecer") na antigüidade clássica para mostrar como essa separação, presente até nossos dias, foi fundada na divisão do trabalho e na exploração, e confere à cultura, do lado do belo, uma independência da civilização, do lado do útil, que contribui para a perpetuação do estado de coisas vigente:

\footnotetext{
Seu traço decisivo é a afirmação de um mundo mais valioso, universalmente obrigatório, incondicionalmente confirmado, eternamente melhor, que é essencialmente diferente do mundo de fato da luta diária pela existência, mas que qualquer indivíduo pode realizar para si 'a partir do interior', sem transformar aquela realidade de fato. (MARCUSE, 1997, p. 96)
}

O próprio Marcuse aponta, no decorrer desse artigo, como o caráter afirmativo da cultura é também dialético. Se, por um lado, essa separação é falsa e legitima a miséria e a servidão, por outro, também é verdadeira na medida em que "pressupõe aquela verdade superior segundo a qual nesse mundo é possível uma forma da existência social em que a economia não decide acerca de toda a vida dos indivíduos" (ibid., p. 109).

Ora, até aqui o problema está colocado em termos muito semelhantes ao que vimos na primeira parte, a respeito da dialética entre cultura e sociedade. Lá, ao final, prometemos retomar esse texto de Marcuse mais à frente - no caso, agora - e fizemos isso por um motivo: porque neste já encontramos em linhas gerais a solução que Adorno propõe na Teoria Estética para esse problema da emancipação da cultura numa sociedade não emancipada, e que acom-

50 Artigo que, segundo ele próprio, foi estimulado por um anterior de Horkheimer. Ver nota do autor em Marcuse (1997), p. 131. 
panhamos brevemente, de certo modo, desde Kant, Schiller e Goethe, e que vimos agora como ele e Horkheimer delimitaram na Dialética do Esclarecimento. A solução será justamente a superação do próprio "caráter afirmativo" da cultura:

A superação efetiva da cultura afirmativa não implicará uma demolição da cultura em geral, mas sim uma eliminação do seu caráter afirmativo. (ibid., p.127)

E mais à frente:

Uma vez que a cultura se apresentou no pensamento ocidental apenas como cultura afirmativa, a supressão de seu caráter afirmativo produzirá efeitos como se fosse a supressão da própria cultura (ibid., p. 128, grifo nosso)

Note o caráter de aparência (necessária, não ideológica) da supressão da cultura. É no mesmo sentido que Adorno chama a atenção para a perda de evidência da arte, logo na primeira frase. Se ele afirma não sabermos mais até que ponto a arte é possível em nos nossos dias, não é para ratificar sua demolição, mas sim para abrir caminho para a arte possível:

\footnotetext{
Perante aquilo em que se torna a realidade, a essência afirmativa da arte, essa essência ineluctável, tornou-se insuportável. Deve voltar-se contra o que constitui o seu próprio conceito e torna-se, por conseguinte, incerta até ao mais íntimo da sua textura. Não deve, porém, pôr-se de lado por uma negação abstracta [...] E é igualmente impossível reduzi-la a uma fórmula universal da consolação ou ao seu contrário. (ADORNO, 2006, p. 12, grito nosso)
}

Isso é de extrema importância, porque aqui, repetimos, Adorno aponta o caminho deixado aberto à arte; e, portanto, à cultura. Negá-la abstratamente significaria anulá-la; tratar, como faz o esclarecimento, a ausência de evidência, aquilo que foge à assimilação imediata - e utilitária -, como desmerecido de existência. Não é assim. Para Adorno, ela precisa ser negada - sua afirmação pura e simples seria se conformar a essa realidade -, porém devemos negá-la mediante negação determinada, não abstrata. Não se trata de dizer simplesmente que ela não é possível, que ela não pode mais ser coisa alguma, se trata de pensarmos sobre o que, em que sentido, ela não pode mais ser, para que pensemos então também no que, e em que sentido, ela pode ainda ser.

Colocado isso, Adorno apresenta então, do $\$ 2$ até o $\$ 4$, as linhas gerais de um conceito negativo de arte, que cumpra as exigências de uma dialética materialista, isto é, que leve 
em conta sua relação com a sociedade (em seu caráter histórico) e as contradições que essa relação implica: "A arte tem seu conceito na constelação de momentos que se transformam historicamente; fecha-se assim à definição" (ibid., p. 12). É a primeira definição - enxuta e, ainda assim, não redutora. Mais à frente ele desenvolve em outras palavras:

\begin{abstract}
A definição do que é a arte é sempre dada previamente pelo que ela foi outrora, mas apenas é legitimada por aquilo em que se tornou, aberta ao que pretende ser e àquilo em que poderá talvez tornar-se. (ibid., p. 13)
\end{abstract}

Essa definição coloca Adorno, como ele argumenta nesses parágrafos, contra um conceito de arte que a reduza à sua origem e contra um conceito que paralise ou essencialize suas categorias e, com elas, as transformações históricas:

\footnotetext{
Muitas obras, por exemplo, representações cultuais, metamorfoseiamse em arte ao longo da história, quando o não tinham sido; e muitas obras de arte deixaram de o ser. (ibid., loc. cit.)
}

Nas definições que se fundamentam na gênese - para a qual sequer há "datas precisas", segundo ele - proliferam "a acumulação positivista de materiais e a especulação habitualmente detestada pelas ciências" (ibid., loc. cit.). Esse tipo de definição coloca em risco a própria arte, pois se pudéssemos deduzi-la de sua gênese, quando os fundamentos desta são abalados, a própria arte desmoronaria.

Contra uma concepção romântica que afirma que as primeiras formas de arte seriam as mais "elevadas e puras", Adorno argumenta que se pode sustentar com igual direito que as primeiras obras eram inseparáveis das práticas mágicas e da documentação histórica, podendo ser consideradas, por isso, então, "confusas e impuras". ${ }^{1}$

Se não é da origem que devemos deduzir o conceito de arte, do que seria então? Vejamos o que ele nos diz:

51 Nesse sentido, por exemplo, mais a frente, Adorno lembra que as grandes epopéias, em seu início confundiam-se com a "narrativa histórica e geográfica”, e a tragédia, do mesmo modo, era a princípio "a cópia de práticas cultuais concebidas como possuindo efeitos reais” (ibid., p.17). Sobre essa função da epopéia é possível encontrar elementos na mesma direção em Auerbach (2009), enquanto no tocante à tragédia e sua função originária de culto remetemos à Gassner (1991). 
A arte só é interpretável pela lei do seu movimento, não por invariantes. Determinase na relação com o que ela não é. O carácter artístico específico que nela existe deve deduzir-se, quanto ao conteúdo, do seu Outro; apenas isto bastaria para qualquer exigência de uma estética materialista dialética. (ibid., p. 13, grifo nosso)

Devemos, portanto, deduzir o que é arte do seu Outro, a sociedade, em todas as suas instâncias, tanto passadas quanto futuras.

Adorno, como Hegel, será avesso a definições nominalistas. Dizer o que a arte é, positivamente, seria desconsiderar sua natureza histórica. Qualquer definição, para Adorno, precisará conter em si a história e o devir da coisa, sobre os quais nunca podemos lançar luz completamente..$^{2}$ Deve sempre permanecer algo de negativo, se queremos ser fiéis à coisa. Só que diferentemente de Hegel, para Adorno não basta assinalar o caráter histórico do conceito para depois resolver as contradições numa síntese abstrata. O conceito de arte, para ele, está intimamente ligado a esse Outro, exterior a ela, o mundo empírico, ao qual ela se opõe, mas o qual também constitui, já que seus materiais não provêm de lugar outro que não o próprio mundo empírico. Ele não resolve a contradição na teoria, mas a sustenta, como fidelidade ao objeto.

Desse modo, se Hegel acertou por um lado, por outro, ao essencializar as categorias históricas, colocou a arte igualmente em risco. O caráter de efemeridade da arte Hegel tentou suplantar com a idéia de que a arte era apenas um momento no desenvolvimento do Espírito absoluto e por isso teve que conceber que aquela estava em declínio, para dar caminho à realização deste; e com isso, para Adorno, Hegel não conseguiu extrair uma conseqüência possível do "caráter ambíguo" do seu sistema: de que "a arte poderia ter o seu conteúdo na sua própria efemeridade" (ibid., p. 14).

O declínio da arte e sua possível morte, para Adorno, não é posto em termos de um destino quase profético que a arte tem no caminho do Espírito absoluto, mas como uma manifestação da contradição da sociedade erguida sob a égide da divisão do trabalho:

52 "O conhecimento não possui nenhum de seus objetos completamente. Ele não deve promover o aparecimento do fantasma de um todo.” (ADORNO, 2009, p. 20) 


\begin{abstract}
Mas a arte e as obras de arte estão voltadas ao declínio, porque são não só heteronomamente dependentes, mas porque na própria constituição da sua autonomia, que ratifica a posição social do espírito cindido segundo as regras da divisão do trabalho, não são apenas arte; surgem também como algo que lhe é estranho e se lhe opõe. Ao seu próprio conceito está mesclado o fermento que a suprime. (ibid., p. 15)
\end{abstract}

Isto é, aqui Adorno nem fala apenas de mundo empírico genericamente, de modo que pudesse ser pensando erroneamente como a-histórico (um Outro sempre presente e essencialmente o mesmo); ele fala das "regras da divisão do trabalho" (tal como vimos também em Marcuse, 1997), o que implica o modo como estas se constituíram no decorrer da história e, portanto, sem postular nada de absolutamente necessário, transcendental ou universal. Nessa perspectiva, o declínio da arte - e seu possível fim - é uma possibilidade histórica concreta, dentre outras, da mesma forma que, em contrário, a arte poderia sobreviver "numa sociedade que teria sido libertada da barbárie da sua cultura" (ibid., p. 14).

Outro ponto que podemos destacar ainda da argumentação sobre como a arte não pode ser deduzida de sua gênese, mas do seu Outro, sem nos alongarmos demais, é o da compulsão à identidade. Se no mundo desencantado, tal qual promove o esclarecimento, os objetos são todos forçados a uma identidade com o sujeito, o sujeito transcendental do conhecimento; para Adorno, as obras de arte têm sua especificidade justamente por procurarem escapar desse destino, e fazem isso quando aspiram, antes de tudo, a uma identidade consigo mesmas. Em outras palavras, isso significa que não se deixam reduzir a um significado unívoco, mas que se apresentam, enquanto alteridade, à interpretação:

Só em virtude da separação da realidade empírica, que permite à arte modelar, segundo as suas necessidades, a relação do Todo às partes é que a obra de arte se torna Ser à segunda potência. As obras de arte são cópias do vivente empírico, na medida em que a este fornecem o que lhes é recusado no exterior e assim libertam daquilo para que as oriente a experiência externa coisificante [...] As obras são vivas enquanto falam de uma maneira que é recusada aos objectos naturais e aos sujeitos que as produzem. Falam em virtude da comunicação nelas de todo o particular. (ibid., p. 15)

Como se pode notar, aquilo que a experiência externa coisificante - experiência típica do esclarecimento enrijecido - nega às coisas é permitido às obras: a comunicação do particular. Não se deixando submeter completamente à identidade para com o sujeito elas defendem o "não-idêntico" oprimido na realidade (ibid., loc. cit.). E mais, Adorno sublinha de diversas 
formas como escapar dessa compulsão à identidade, desse terrível destino, é justamente o que lhes confere vida ("fala", "Ser à segunda potência").

Essa vida não é uma vida propriamente humana, isso é evidente, segundo Adorno. "Afirmar que enquanto artefactos, produtos humanos, elas não vivem directamente como homens, é uma tautologia" (ibid., loc. cit.). Mas é uma espécie de vida, por esse estatuto de alteridade e autonomia que adquirem.

Nesse sentido, um pouco à frente, ainda no $\S_{4}$, Adorno se vale mais uma vez do modelo da mônada de Leibniz ${ }^{53}$ :

\footnotetext{
Que as obras de arte, como mônadas sem janelas, "representem" o que elas próprias não são, só se pode compreender pelo facto de que a sua dinâmica própria, a sua historicidade imanente enquanto dialética da natureza e do domínio da natureza não é da mesma essência que a dialéctica exterior, mas se lhe assemelha em si, sem a imitar. (ibid., p.16)
}

Como prometido na parte II, podemos ver agora o modelo da mônada aplicado também à arte: mais uma vez significando independência relativa, "assemelhar-se sem imitar". A mônada é o particular que reflete o todo sem deixar de ser um particular. Ela realiza, no particular, uma síntese do todo que a abstração não consegue fazer sem perder o particular. Em outras palavras, aquilo que podemos abstrair enquanto conteúdo de um determinado momento social está presente também nas obras de arte, mas não diretamente, pois esse conteúdo participa da obra enquanto sedimento constituinte da sua forma, essa mediação preserva o particular.

53 Adorno já havia usado esse modelo para falar sobre a arte em outros momentos. Ver por exemplo Adorno (2001b [1945]): "Mas a relação entre a obra de arte e o conceito universal não é uma relação direta. Se devesse expressar isto de maneira brutal deveria tomar emprestada uma famosa metáfora da história da filosofia. Deveria comparar a obra de arte a uma mônada. De acordo com Leibniz, cada mônada 'representa' o universo, mas não tem janelas; representa o universal dentro de suas próprias paredes. Ou seja, sua estrutura é objetivamente a mesma do universal. Pode ter consciência disso em diferentes graus. Mas não tem acesso imediato à universalidade, não olha para ela, por assim dizer. Não importa o que consideremos dos méritos lógicos ou metafísicos desta concepção: parece-me que expressa com adequação a natureza da obra de arte. A arte não pode tornar os conceitos como seu 'tema'. O relacionamento da obra de arte com o universal torna-se tanto mais profundo quanto menos a obra tenha a ver explicitamente com universalidades, quanto mais se impregne com seu próprio mundo em destaque, com seu material, seus problemas, sua consistência, sua maneira de expressar-se. Apenas atingindo o ápice da individualização genuína, apenas obstinadamente seguindo os desideratos de seu concretizar-se é que a obra se torna verdadeiramente portadora do universal." (pp. 24-25) 
Por exemplo, a arte no seio da burguesia vai refletir, além dos valores burgueses, todas as contradições da sociedade burguesa, porém, cada obra fará isso de forma diferente. Não é possível resumir todas a uma mesma idéia, cada uma delas vai reter o particular de forma, até certo ponto, irredutível a uma abstração.

Não é à toa que o modelo da mônada é aplicado por Adorno a esses dois objetos: o indivíduo e a obra de arte. É em torno justamente dessa síntese momentânea, dessa "cristalização" dos antagonismos sociais no particular de uma obra, que uma das analogias mais interessantes entre arte e indivíduo será feita por Adorno:

\begin{abstract}
Assim, o puro conceito de arte não constituiria o círculo de um domínio garantido de uma vez por todas, mas só se produziria de cada vez, em equilíbrio momentâneo e frágil, muito comparável ao equilíbrio psicológico do Ego e do Id. O processo de repulsa deve continuamente renovar-se. Cada obra de arte é um instante; cada obra conseguida é um equilíbrio, uma pausa momentânea do processo, tal como ele se manifesta ao olhar atento. (ibid., p.17)
\end{abstract}

Esse é o primeiro momento da Teoria Estética em que Adorno compara arte e indivíduo pelo viés de sua gênese. Tanto um quanto outro surgem da sociedade, do todo, mas se mantêm enquanto particular, não sem problemas, mas através de um equilíbrio momentâneo. Em outros momentos, os quais veremos mais à frente, Adorno faz a mesma comparação, porém nos dando outros elementos.

$\mathrm{Na}$ segunda parte desse fragmento, dos $\$_{5}-8$, encontramos um desenvolvimento sobre a questão do interesse/desinteresse na produção das obras de arte, no qual Adorno analisa a posição da psicanálise e de Kant, para superá-las.

No início dessa parte, $\$_{5}$, há praticamente um resumo da parte anterior, numa frase lapidar: "A arte é a antítese social da sociedade, e não deve imediatamente deduzir-se desta" (ibid., p. 19). Mas o que ele escreve logo em seguida é o que nos interessa particularmente:

\footnotetext{
A constituição da sua esfera corresponde à constituição de um meio interior aos homens enquanto espaço da representação: ela toma previamente parte na sublimação. É, portanto, plausível extrair a definição do que é a arte a partir de uma teoria do psiquismo. (ibid., p. 19, grifo nosso)
}

Isto é, a constituição da esfera da arte está ligada à constituição de um espaço de representação subjetiva, a ponto de se poder extrair a definição de uma a partir da outra. Isso 
é muito importante. Já que pretendemos pensar a relação entre arte e formação do indivíduo, temos de frisar que essa será a primeira vez na Teoria Estética que tal relação será tão evidente. Enquanto no trecho da página 17, citado por nós anteriormente, em que Adorno fala sobre o equilíbrio momentâneo da obra "muito comparável" ao equilíbrio entre Ego e Id, a relação entre arte e indivíduo ainda podia ser lida como simples analogia, agora, no trecho acima, vemos claramente que é mais que isso.

O problema com que Adorno se depara, a partir dessa constatação, de que "é plausível extrair a definição do que é a arte a partir de uma teoria do psiquismo", é saber se as teorias do psiquismo, até então, eram satisfatórias ou não. Por isso ele recorreu a Freud e Kant, dois grandes teóricos da subjetividade e que pensaram também a produção e recepção artísticas. Como veremos rapidamente, para Adorno, a teoria de ambos não foi satisfatória.

A psicanálise errou por excesso de imanência psíquica na consideração a respeito da arte. Trouxe o mundo para a obra, mas reduziu o mundo ao desejo do indivíduo:

Ao transferir simplesmente as obras de arte para a imanência psíquica,
despoja-as da antítese ao não-eu. Este permanece intacto às picadas
das obras de arte, que se esgotam na realização psíquica do domínio da
renúncia pulsional, e, no fim das contas, na adaptação. (ibid., p. 23)

Para Adorno, o "elemento projetivo" tem um papel importante na produção artística, mas é apenas um momento - existem outros: “o idioma, o material e sobretudo o próprio produto tem um peso específico" (ibid., p. 19). Ou seja, o processo de produção artística envolve outros elementos do mundo para os quais a teoria psicanalítica, isolada, não tinha ferramentas para pensar.

A mesma expulsão do mundo se dá em Kant, de outra maneira. O sujeito transcendental kantiano vê o que é exterior ao sujeito como um cerceador de sua liberdade. Para Adorno, o desinteresse que representa a autonomia da esfera estética (ponto forte de Kant) deve “juntar-se à sombra do interesse mais feroz" (ibid., p. 22), senão é simples indiferença. Assim, a satisfação desinteressada de Kant, por si só, para Adorno, é uma espécie de "hedonismo castrado" (ibid., p. 23).

Em outras palavras, para a psicanálise seria imprescindível a consideração do interesse na produção da obra: os desejos inconscientes do artista. Já a teoria kantiana seria “a 
antítese da teoria freudiana da arte enquanto teoria da realização do desejo" (ibid., p. 20). Se a teoria psicanalítica tem o mérito de trazer o mundo, o exterior, para a obra, Kant, ao separar o sentimento estético da faculdade de desejar, evita que a arte seja tomada como um simples meio de satisfação. Claro que, mesmo para Freud, Adorno nos diz, "as obras não são imediatamente realizações de desejos" (ibid., p. 21), no entanto, Kant realçou muito mais a separação entre arte e satisfação, arte e empiria, e com isso, preservou o campo da arte. O problema de Kant, porém, diz Adorno, é que ele fixou transcendentalmente essa constituição (enquanto separação da empiria), sendo que esta é um produto da história (ibid., p. 22). Vejamos qual será a posição de Adorno:

\begin{abstract}
As obras de arte implicam em si mesmas uma relação entre o interesse e a sua recusa, contrariamente à interpretação kantiana e freudiana. Mesmo o comportamento contemplativo perante as obras de arte, extirpado dos objetos da ação, se experimenta como denúncia de uma práxis imediata e, por conseguinte, como algo também prático, como resistência em envolver-se. [...] A arte não é unicamente o substituto de uma práxis melhor do que a até agora dominante, mas também crítica da práxis enquanto dominação da autoconservação brutal no interior do estado de coisas vigente e por amor dele. Censura as mentiras da produção por ela mesma, opta por um estado da práxis situado além do anátema do trabalho. Promesse de bonheur significa mais do que o facto de que, até agora, a práxis dissimula a felicidade: a felicidade estaria acima da práxis. A força da negatividade na obra de arte mede o abismo entre a práxis e a felicidade. (ibid., pp. 23-24)
\end{abstract}

Há três pontos principais que queremos destacar da citação acima: a relação entre o interesse e sua recusa na produção e recepção artísticas; a práxis que isso representa e a relação dessa práxis com a felicidade. Isto é, sendo social e ao mesmo tempo antítese da sociedade, a obra é também, em parte, realização de um desejo do artista que a produziu ou da pessoa que a contempla, porém ela não é apenas isso. Pressupor a produção e a recepção artística como mais do que a simples intenção do sujeito que produz ou contempla é se recusar a reduzir o objeto ao sujeito. O objeto é mais que o sujeito. Essa recusa, em si mesma, já é práxis. Não aceitar os pressupostos de uma racionalidade que reduz a arte ao interesse, sem se esquecer de que arte também é interesse, é estar em franco desacordo com a práxis dominante.

Mas o que seria esse "mais que o sujeito"? Adorno não dirá positivamente. Se o fizesse estaria participando da racionalidade que procura combater. Como se pode ver na citação, a filosofia de Adorno vai buscar a força da obra de arte justamente na sua "negatividade", ou seja, naquilo que ela contém que não pode ser positivado. Mas essa negatividade não é absoluta, senão seria anulação e não a concepção de negatividade de Adorno, herdeira da "negação deter- 
minada" hegeliana.54 Em outras palavras, a positividade se encontrará, em Adorno, no desenvolvimento das negações. Nesse sentido, note as pistas que encontramos na citação anterior: se a produção, em nossa sociedade, está sob o "anátema do trabalho", a produção artística tem que ser "mais" que o trabalho. Desse modo, se o trabalho, até hoje, esteve aliado ao sacrifício, à infelicidade, a práxis que a arte representa é, portanto, sua negação: é uma promessa de felicidade. Nos dois últimos parágrafos, porém, Adorno vai nos prevenir do equívoco de se confundir essa promessa de felicidade com o prazer gerado pelas obras de arte. Segundo ele não é errado, em si, que se sinta prazer com a arte, o problema é que, em nossa sociedade, o prazer que a arte gera não é o prazer de uma reconciliação com a natureza do corpo, mas um gozo de sua prisão - a "utilidade" do burguês:

\footnotetext{
O momento de prazer na arte, protesto contra o carácter universal e mediatizado de mercadoria, é à sua maneira mediatizável: quem desaparece na obra de arte é por isso dispensado da miséria de uma vida, que é sempre demasiado escassa [...] Se a arte é já inútil para o sistema da autoconservação - o que a sociedade burguesa nunca lhe perdoou -, deve pelo menos preservar-se através de um tipo de valor de uso, decalcado sobre o prazer sensual. (ibid., p. 25)
}

No segundo fragmento da Teoria Estética encontraremos o desenvolvimento de algumas dessas questões, assim como outra faceta do conceito de arte que muito nos interessa.

\section{Arte Moderna Radical}

No fragmento anterior vimos que o conceito de arte para Adorno é historicamente determinado. No presente capítulo, dedicado ao segundo fragmento, por sua vez, testemunhamos algo de seu desenvolvimento, o que é isso que ele chama de arte moderna radical, o que é moderno e qual sua relação com a tradição, e ainda - o que nos interessa abordar especialmente - qual é o papel do indivíduo nisso.

54 Para Hegel, segundo Safatle (2006), uma negação determinada é diferente de uma oposição, de uma negação indeterminada. Por exemplo, quando dizemos "A mulher não é alta”, estamos operando uma negação determinada, quando dizemos "A mulher não é homem" estamos operando uma oposição. No último caso a negação leva diretamente ao seu termo oposto. Na negação determinada a coisa negada se mantém. 
Adorno não cai no erro, muito freqüente, de apresentar um conceito como historicamente determinado para logo em seguida lhe dar um tratamento ontológico; como se fosse possível livrar-se assim, logo de cara, da "consciência pesada da história" e voltar ao trabalho então sem mais pensar nela. Neste fragmento podemos acompanhar o cuidado, e o trabalho, do autor em não apenas situar o presente em relação ao passado - não é à toa que a palavra-chave que acompanha este seja Situação -, mas em também não esquecer do passado aquilo que não pode, nem deve, ser esquecido.

Em nossa época, segundo ele, do mesmo modo em que as categorias que definiam a arte deixaram de ser evidentes - como vimos no fragmento 1-, os materiais também perderam sua "evidência apriórica" (ibid., p. 27). Os materiais sofreram uma decomposição e, com isso, se perdeu algo de sua "substancialidade."

O que isso significa? Grosso modo, para nós, significa um desenvolvimento, por parte de Adorno, da concepção de linguagem e sua relação com a história advindas de Benjamin, em especial, do seu conceito de alegoria, tal como vimos no capítulo 1, da parte I, e sua concepção de conteúdo de verdade, como veremos melhor num capítulo adiante.

Retomemos, porém, antes da análise desse fragmento propriamente, a concepção de Adorno, conjunta com Horkheimer na Dialética do Esclarecimento, a respeito da separação conceito-coisa (ou, dito por vezes, signo-imagem) e vejamos como essa idéia já ganhava corpo no pensamento de Adorno nessa última.

Nela encontramos, por exemplo, que, no mito, o signo e a imagem coincidem:

Os mitos, assim como os ritos mágicos, têm em vista a natureza que se repete. Ela é o âmago do simbólico: um ser ou um processo representado como eterno porque deve voltar sempre a ocorrer na efetuação do símbolo. Inexauribilidade, renovação infinita, permanência do significado não são apenas atributos de todos os símbolos, mas seu verdadeiro conteúdo. (ADORNO; HORKHEIMER, 1985, pp. 30-31, grifo nosso) 
O significado original do signo, no mito, desse modo, é a própria repetição. Isso não significa, porém, que devamos invejar essa “conjunção original”. O esclarecimento foi um avanço em relação aos mitos. Segundo os autores, já na epopéia homérica ${ }^{55}$ podemos encontrar o início da separação entre o conceito e a coisa - separação esta que, porém, será hipostasiada com o esclarecimento (ibid., pp. 29-30). Em outras palavras, superar a coincidência entre signo e imagem é, de certo modo, tentar superar a submissão do homem à repetição da natureza:

O conceito, que se costuma definir como a unidade característica do que está nele subsumido, já era desde o início o produto do pensamento dialético, no qual cada coisa só é o que ela é tornando-se aquilo que ela não é. (ibid., p. 29)

O problema é que, com o esclarecimento, mais uma vez, aquilo que podia ser libertador se mostrou como uma nova prisão. A coerção social exigida - nos dois sentidos do verbo: pré-requisito e demanda - para a pretensa separação absoluta entre signo e imagem não é melhor que a escravidão às forças da natureza..$^{56}$

No trecho a seguir pode-se perceber uma dimensão um pouco mais desenvolvida de tal problema:

Com a nítida separação da ciência e da poesia, a divisão de trabalho já efetuada com sua ajuda estende-se à linguagem. É enquanto signo que a palavra chega à ciência. Enquanto som, enquanto imagem, enquanto palavra propriamente dita, ela se vê dividida entre as diferentes artes, sem jamais deixar-se reconstituir através de sua adição, através da sinestesia ou da arte total. Enquanto signo, a linguagem deve resignar-se ao cálculo; para conhecer a natureza, deve renunciar à pretensão de ser semelhante a ela. Enquanto imagem, deve resignar-se à cópia; para ser totalmente natureza, deve renunciar à pretensão de conhecê-la. (ibid., p. 31)

Esse trecho é de suma importância. Nele encontramos uma vinculação entre a separação da ciência e da poesia, a divisão do trabalho e a linguagem que é de excepcional clareza.

55 Importante lembrar que as epopéias de Homero, a Ilíada e a Odisséia, não são os mitos na sua forma “original” - se é que se pode falar assim -, aquilo que é perpetuado pela transmissão oral. A epopéia é uma compilação de mitos e, como compilação, já participa ativamente do esclarecimento.

56 "Os símbolos assumem a expressão do fetiche. A repetição da natureza, que é o seu significado, acaba sempre por se mostrar como a permanência, por eles representada, da coerção social. O sentimento de horror materializado numa imagem sólida tornase o sinal da dominação consolidada dos privilegiados. Mas isso é o que os conceitos universais continuam a ser mesmo quando se desfizeram de todo aspecto figurativo. A forma dedutiva da ciência reflete ainda a hierarquia e a coerção" (ibid., p. 34). 
Pode-se notar que a separação da ciência e da poesia não foi mera arbitrariedade histórica, ela refletiu e produziu, ao mesmo tempo, a divisão do trabalho. E a linguagem não se prestou a essa separação de forma externa, como uma mera ferramenta, uma e mesma, usada ora pela ciência e ora pela poesia. Pelo contrário, tal separação, assim como a divisão do trabalho a ela vinculada, produziu mudanças internas na linguagem. Ao signo, que ficou do lado da ciência, coube o cálculo apenas, e a imagem, que ficou do lado da arte, foi relegada à cópia. "Só as obras de arte autênticas", os autores continuam na seqüência, "conseguiram escapar à mera imitação daquilo que, de um modo qualquer, já é” (ibid., p. 31).

Aqui já encontramos, então, uma distinção entre as artes - mais especificamente entre as obras de arte, não entre suas modalidades - que será desenvolvida, acreditamos, na Teoria Estética. Se o esclarecimento reduziu a arte à cópia, com a correlata redução do seu aparato lingüístico à imagem, não foi toda a arte que teve esse destino. Alguma arte escapou, mas qual?

Um pouco mais à frente eles explicam, num trecho que já utilizamos a propósito da relação entre arte e magia, no capítulo anterior, mas que nos serve novamente. Nele, os autores apontam que tal arte é aquela que consegue se manter como um domínio separado e ao mesmo tempo interligado à sociedade:

\footnotetext{
Neste domínio [da arte] imperam leis particulares [...] É exatamente a renúncia a agir, pela qual a arte se separa da simpatia mágica, que fixa ainda mais profundamente a herança mágica. Esta renúncia coloca a imagem pura em oposição à realidade mesma, cujos elementos ela supera retendoos (aufhebt) dentro de si. Pertence ao sentido da obra de arte, da aparência estética, ser aquilo em que se converteu, na magia do primitivo, o novo e terrível: a manifestação do todo no particular. (ibid., p. 32, grifo nosso)
}

Esse trecho contém, em germe, muito do que viemos trabalhando até aqui. Note, há uma maneira de se opor à realidade sem "agir", esse modo é um modo de aparência, imagético; se refere ao todo, mas esse todo tem sua manifestação no particular. Se forçarmos um pouco e pensarmos a renúncia a agir como a evitação da barbárie (por exemplo, da Revolução Francesa) e a aparência estética como um correlato do modo de ser de uma nobreza ideal a ser buscado pelo burguês (tal qual vimos no Meister, de Goethe), estamos praticamente cortando todo o caminho final ainda a ser percorrido, para dizer: a arte forma, não qualquer arte, mas a arte que pode ser aparência, sem ser, com isso, consolação. Mas não nos adiantemos tanto. 
O que nos interessa especialmente dessa longa digressão para que retornemos ao ponto em que estávamos - o problema dos materiais artísticos e as condições para a existência do que Adorno chama de obra de arte moderna radical - é: para Adorno, já desde A Idéia de História Natural, como vimos no capítulo 1 da parte I, assim como também na Dialética do Esclarecimento, como vimos agora, o uso do material não é arbitrário, pois os signos e as imagens guardam a história do homem.

Em resumo, portanto, no mito, signo e imagem significam - por meio de sua identidade - a repetição da natureza; no esclarecimento sob o paradigma da razão técnica - por meio de sua separação - signo e imagem significam barbárie: a repetição social e a coerção a ela associada; no esclarecimento que inclui a mímesis, por sua vez - por meio da relação dialética entre ambos - signo e imagem significam a possibilidade de liberdade frente à repetição da natureza e à coerção social..$^{57}$ Vejamos, então, como isso está desenvolvido na Teoria Estética.

Os materiais artísticos, podemos pensar, a princípio, são tudo aquilo que compõe a obra em sua materialidade, como a pedra, o bronze, as palavras, os sons, as cores, as telas, o óleo etc. Dizíamos que Adorno, ainda no início do fragmento 2, coloca a tese de que na época atual os próprios materiais, além das categorias artísticas, também perderam sua evidência apriórica. Segundo ele, o que ocorre, nos nossos dias, é uma “decomposição dos materiais" (ADORNO, 2006, p. 27); decomposição no sentido de desintegração (consta o termo desintegration na edição americana: ADORNO, 1996, p. 16).

Adorno acha possível considerar, por exemplo, toda a poesia neo-romântica como uma tentativa de resistir a essa dissolução dos materiais. Ele nos fala de um poema de Stefan George (1868-1933) em que a escolha minuciosa de apenas duas palavras foi necessária para evocar, com "brilho poético", uma floresta, e que, 60 anos depois (data aproximada em que Adorno escreveu Teoria Estética, já que o poema, Sétimo Anel, foi publicado em 1907 e a Teoria Estética estava sendo escrita ainda em 1967), a escolha das palavras "tornou-se reconhecível como mero

57 Note a diferença do estatuto do significado nos três casos. Nos dois primeiros, mito e razão técnica, o estatuto do significado é afirmativo: repetição da natureza e coerção social, respectivamente; no terceiro, razão mimética, o estatuto do significado é negativo: a possibilidade de não ser nem um nem outro dos anteriores. Abre-se assim, no terceiro caso, toda uma gama de possibilidades afirmativas de significado diferenciadas entre si. 
arranjo decorativo ${ }^{58 ”}$ (ADORNO, 2006, p. 28). Outro exemplo que ele nos dá é o comentário de Schönberg a respeito de Chopin, segundo qual este último tivera sorte porque lhe bastou utilizar a tonalidade de fá sustenido maior, “então abandonada, para fazer música bela”, e que, por outro lado, as tonalidades requintadas de Chopin, em 1900, já se tinham “depravado para o nível da seleção" (ibid., p. 28).

Para Adorno, assim, os materiais não são imunes à ação do tempo - sofrem contínuo desgaste. Decorrência lógica: se a sociedade não é a mesma e os materiais contêm a história da sociedade, como podem os materiais usados continuarem os mesmos e ainda assim expressarem a história da sociedade com verdade? Já desde Benjamin, quando este fala sobre o caráter histórico da alegoria, como vimos, a alegoria é comparada a ruínas.

Em Adorno, ganha ênfase a idéia de que com materiais desgastados não apenas se expressa a história da sociedade (também, de certo modo, desgastada), mas só se expressa essa história como ideologia ou resignação.

Justamente por conter a história do homem, o uso dos materiais que se resigna a repetição da tradição coaduna com uma sociedade que pretende eliminar o futuro. Para Adorno, "nada é tão prejudicial ao conhecimento teórico da arte moderna como a sua redução a semelhanças com a arte anterior" (ibid., p. 31), enquanto o Novo, por sua vez, "é o sinal estético da reprodução ampliada, juntamente com a sua promessa de abundância ilimitada" (ibid., p. 33).

Tomaremos o elogio de Adorno a Beckett, presente ao longo desse fragmento, como exemplo do que foi dito acima:

O que se subtrai às modificações do material, que as inovações importantes trazem consigo, e o que se lhes esquiva depressa aparece como esvaziado de substância e pobre [...] basta, após uma peça de Beckett, ter visto uma peça contemporânea mais moderada, para se cair na conta de até que ponto o Novo julga sem juízo. (ibid., p. 32)

58 Curioso é o exemplo que ele dá dessa dissolução: o Dorian Gray de Wilde, obra na qual, segundo Adorno, a acumulação de materiais se assemelha às lojas de antigüidade, aos leilões e ao comércio que o próprio Wilde execrava (ADORNO, 2006, p. 28; id., 1996, p. 16). Curioso porque Wilde publicou Dorian Gray 17 anos antes do Sétimo Anel de George. Isso corroboraria com a hipótese de que a periodização da arte feita por Adorno na Teoria Estética seja uma análise de tendências e que obras de determinada época podem conter características diferentes da tendência geral daquele período. Ver também, mais à frente, a especificidade do conceito de moderno em Adorno. 
Ou seja, o que Adorno "chama de peça contemporânea mais moderada" se subtraiu, se esquivou das modificações do material, utilizou materiais que já não contam a verdade histórica da sociedade e, por isso, são esvaziados de substância.

Qual é essa verdade histórica da sociedade que está presente nos materiais das obras modernas radicais, Adorno não deixa dúvidas: é o sofrimento e a infelicidade (ibid., p. 30). Ele diz:

Ao exprimir a infelicidade pela identificação, antecipa a sua perda de poder; isto, e
não a fotografia da infelicidade nem a falsa beatitude, circunscreve a posição de
uma arte actual autêntica relativamente a objetividade entenebrecida. (ibid., p. 31 )

Note que não é a mera fotografia da infelicidade que já torna a arte autêntica, isto é, não basta a obra reproduzir conteudisticamente a infelicidade do mundo. Quando Adorno fala “ao exprimir a infelicidade pela identificação", está implícita a concepção adorniana da mímesis.

Para Adorno o momento abstrato do Novo é necessário (ibid., p. 32). Momento este ligado ao seu caráter de mercadoria (ibid., p. 33). Porém, isso não significa que seja possível esquecer a infelicidade envolvida nesse caráter mercadológico - a coerção e o sacrifício - mesmo na arte mais "alegre". Em Baudelaire, quando se articula teoricamente pela primeira vez a modernidade, segundo ele, esta já tem o tom da infelicidade, e "onde quer que o moderno, até hoje, negue isso, capitula [...]" (ibid., p. 33).

Contudo, o momento abstrato não é suficiente, a arte só será moderna para Adorno “através da mimese do que está petrificado e alienado" (ibid., p. 33). Para ele, “é o comportamento mimético que reage como mimese à abstração. Só no Novo é que a mimese se une irreversivelmente à racionalidade" (ibid., p. 32). Ou seja, para Adorno, é condição da arte moderna radical o uso de um material que contenha como significação a infelicidade da história humana e que faça isso não por meio de uma representação abstrata, mas mimética.

Essa diferença entre a representação abstrata e a mimética fica clara na diferença que Adorno apontou, diversas vezes, entre Brecht e Beckett. Nesse fragmento, por exemplo, encontramos o seguinte trecho:

A obra de arte, que crê possuir o conteúdo a partir de si, encalha num racionalismo ingênuo: isso poderia constituir os limites historicamente previsíveis de Brecht [...] Dos grandes dramas de Shakespeare, como também das peças de Beckett, não se pode extrair o que hoje se chama de mensagem. (ibid., p. 40) 
No decorrer do fragmento, e da Teoria Estética, depreende-se que, para Adorno, Brecht muitas vezes pecaria por excesso de racionalismo, pretendendo transcender abstratamente a obra na própria obra, acrescentando de modo um tanto forçado a auto-reflexão que supostamente lhe faltaria; tarefa que, como veremos noutro momento, cabe à crítica. Beckett, na imanência da representação mimética, estaria muito mais próximo da verdade, pois, dentre outras coisas, a própria escolha e uso do seu material passa a mensagem do horror, que não poderia ser passada de outro modo sem capitular.

Enquanto alguns críticos, segundo o autor, censuram Beckett, pela "repetição de suas concepções”, como se a obra deste acabasse por resvalar à pobreza de elementos, Adorno verá nessa aparente pobreza a forma mais justa de representar o próprio "empobrecimento do sujeito":

\footnotetext{
[...] no ponto zero em que a prosa de Beckett põe em acção a sua natureza, com as forças no infinitamente pequeno da física, brota um segundo mundo de imagens, tão sinistro como rico, concentrado de experiências históricas que, na sua imediatidade, não atingem o decisivo, isto é, o esvaziamento do sujeito e da realidade. O carácter mesquinho e inútil deste universo simbólico é a cópia, o negativo do mundo administrado. Nesta medida, Beckett é realista. (ibid., p. 44, grifo nosso)
}

Isto é, para Adorno, empobrecidas são as imagens que brotam de um material que não pode mais representar a realidade como esta merece ser representada. E mais, naquilo que alguns consideram como pobre de imagens, Adorno vê "um segundo mundo de imagens", "rico" e "concentrado de experiências históricas".

O que alguns críticos de Adorno, como Bronner (1994), por exemplo, podem enxergar como uma proscrição é na verdade a seleção necessária do material para que o Novo possa surgir. Do contrário seríamos ingênuos, como uma criança "que busca no piano um acorde jamais ouvido, ainda virgem" (ibid., p. 45).

O Moderno, para Adorno, é uma relação com o material, e não apenas o próprio material, por isso o moderno não é uma definição cronológica e, sim, filosófico-histórica:

[O moderno] É antes o postulado rimbaudiano da consciência mais progressista, na qual os procedimentos técnicos mais avançados e mais diferenciados se interpenetram com as experiências mais avançadas e mais diferenciadas. (ibid., p. 47) 
Um material pode ser moderno num determinado momento e não ser em outro. Para Adorno, "o tempo, por si só, não é nenhum critério" (ibid., p. 55). Lembremos que o conceito de arte, para ele, é historicamente determinado; assim, o conceito de moderno não poderia ser diferente.

Desse modo, definir moderno, na atualidade, implica também uma análise da sociedade atual. Por isso a palavra-chave que "intitula" o presente fragmento é "situação" (situation), porque "nada pode esquivar-se à experiência da situação" (ibid., p. 47). Nada pode ser mais livre do que lhe permite a situação.

Desse modo, numa sociedade industrial o moderno vai refletir a experiência possível nessa sociedade:

\footnotetext{
É moderna a arte que, segundo o seu modo de experiência e enquanto expressão da crise da experiência, absorve o que a industrialização produziu sob as relações de produção dominantes. (ibid., p. 47)
}

Se vivemos numa sociedade em que a experiência está em crise, moderno será o material que refletir tal crise, não como simples imagem no espelho, cópia, mas como mônada, que mantém uma autonomia frente ao refletido.

Dessa forma, o termo "reflexão" pode assumir também seu sentido de pensar sobre, criticar. O conteúdo crítico da reflexão mimética é essencial para Adorno:

\footnotetext{
Os vestígios deixados no material e nos procedimentos técnicos, a que adere toda a obra qualitativamente nova, são cicatrizes, os pontos onde as obras precedentes fracassaram [...] O conteúdo de verdade das obras de arte funde-se com o seu conteúdo crítico. (ibid., pp. 48-49)
}

Duas características essencialmente críticas da arte moderna são bastante enfatizadas por Adorno nesse fragmento: a característica utópica e a radical.

A característica utópica diz respeito à possibilidade da arte de transcender o imediato. Porém, essa transcendência engendra uma antinomia muito importante no pensamento de Adorno. Ao mesmo tempo que a arte, por apresentar um outro mundo possível, traz uma promessa de reconciliação, ela não pode ceder à pretensão de ser realização da reconciliação: 


\begin{abstract}
Central nas antinomias actuais é o facto de que a arte deve e pretende ser utopia, e tanto mais decididamente quanto a relação real das funções impede a utopia; e que ela, porém, para não trair a utopia pela aparência e pela consolação, não tem o direito de ser utopia. Se a utopia da arte se realizasse, seria o seu fim temporal. (ibid., p. 45)
\end{abstract}

A característica radical diz respeito à necessidade na arte de ir ao extremo das possibilidades atuais do material. Segundo Adorno, a racionalidade estética exige isso. O moderno realiza, na sua radicalidade, aquilo que na tradição se esgotou e que as obras moderadas não conseguem atingir. "Mesmo aqui convergem a produção material e a produção estética" (ibid., p. 48), diz ele. É como utilizar energia eólica ou hidráulica em moinhos depois do advento da máquina a vapor e da máquina elétrica: "Obras de arte significativas tendem a aniquilar tudo o que, na sua época, não atinge o seu padrão" (ibid., p. 48).

Claro que, por outro lado, essa relação não é absoluta, mas também histórica. O que hoje sucumbe frente ao moderno pode ser moderno de novo em outra configuração. Adorno dá o exemplo da música tonal. Se para ele, naquele momento, ela se mostrava regressiva, podia ser que em outro momento voltasse a ser progressiva (ibid., p. 50). Assim também com a produção material, no exemplo que demos acima. O que numa determinada época é considerado um avanço (não depender do vento), com a mudança histórica (por exemplo, o desenvolvimento de uma consciência ambiental), pode ser considerado retrógrado. Nesse sentido, Adorno afirma que a "unidade da história da arte é a figura dialéctica de uma negação determinada" (ibid., p. 49).

Almeida (2007), que fez um amplo estudo com base também em outras obras de Adorno, especialmente as de estética musical, indica algumas prováveis raízes dessa concepção de material em sua obra, com uma formulação inicial em 1930, para problemas que Adorno já vinha acompanhando e criticando pelo menos desde 1919 (pp. 288-289) e, talvez, portanto, pensamos, antes mesmo da influência de Benjamim. Não vamos nos aprofundar nisso aqui; destacamos apenas um parágrafo conclusivo do autor que corrobora o que trouxemos até o momento e aponta o caminho que ainda vamos trilhar: 


\begin{abstract}
Como todo conceito dialético, também o de "material” escapa à mera definição, não apenas por fazer parte de uma constelação de conceitos, na qual o sentido de cada um depende dos demais, mas principalmente por assumir, em seu próprio sentido, a historicidade que aponta em seu objeto [...] À medida que o material musical se modifica durante a história, seu próprio conceito acompanha essas mudanças, sobrepondo camadas de significado que Adorno irá recuperar, ao torná-lo o ponto central da dialética entre o artista, a obra e a sociedade. (ibid., pp. 287-288)
\end{abstract}

Já vimos como o conceito de material é histórico e dialético, vejamos agora os apontamentos que Adorno fará no fragmento analisado sobre o papel do sujeito nesse contexto. No fragmento anterior, vimos que a constituição da arte estava ligada à constituição da própria subjetividade. No presente fragmento, em que ele situa o momento atual, faz o mesmo com relação ao sujeito, indicando seu papel na constituição da obra de arte moderna.

Para isso, vejamos como ele introduz, nesse fragmento, a dialética entre construção e expressão do sujeito na obra de arte - sobre a qual tratamos mais detidamente em outro capítulo. O que nos interessa destacar aqui é que essa dialética representa, a cada época, o momento atual das forças produtivas.

Segundo ele, a tendência presente na "fase da administração total" (ADORNO, 2006, p. 29) é que a arte perca a sua especificidade. ${ }^{59}$ Ele aponta dois pólos nesse processo: por um lado a arte se torna "coisa entre as coisas" e, por outro, mero "veículo da psicologia do espectador" (ibid., p. 29). Em outros termos, respectivamente, mercadoria e falsa projeção.

O que acontece, segundo Adorno, é que no momento atual a Indústria Cultural põe em andamento e explora o mecanismo que reduz as obras à mercadoria. Enquanto mercadorias, estandardizadas, as obras não falam a partir do lugar da autonomia frente à realidade, possibilidade da liberdade, mas enquanto "simples factum", alienadas de sua autonomia, "coisa entre as coisas". Desse modo, as obras deixam de ser como mônadas, encerrando possibilidades utópicas, mas se tornam “tábula rasa” para as projeções subjetivas também estandardizadas.

Importante lembrar que a Indústria Cultural não criou esse mecanismo, apenas representa o momento em que as forças produtivas levaram este a um desenvolvimento nunca

59 Processo denominado por Adorno pela palavra alemã Entkunstung, a qual o tradutor da edição portuguesa optou por deixar no original, enquanto na edição americana foi traduzido por deaestheticization (algo como "desestetização"), com adição de uma nota explicativa em que se diz que a tradução literal seria "a destruição da qualidade da arte enquanto arte” (ADORNO, 1997, p. 368, tradução nossa). 
antes visto. Assim como vale lembrar também que a arte autônoma não está imune a ele. "A sua autonomia é um ter-estado-em-devir, que constitui o seu conceito, mas não a priori” (ibid., p. 29), diz Adorno.

Vimos na parte I como para Adorno e Horkheimer, na Dialética do Esclarecimento, o que é novo não é o caráter mercantil das obras de arte, mas sim ele se declarar deliberadamente como tal, e que as verdadeiras obras de arte sempre foram ao longo da história, de certo modo, mercadorias - apesar de negarem, ao mesmo tempo, o caráter mercantil da sociedade. Nesse fragmento da Teoria Estética, Adorno está procurando o que pode haver de progressivo na liberdade da arte burguesa, mas não esquece, por outro lado, em momento algum, que "a idéia de liberdade, intimamente ligada à autonomia estética, formou-se na dominação que a generalizava" (ibid., p. 29).

A perda da especificidade da arte representa, por um lado, a capitulação frente ao aspecto regressivo da mercadoria. Completamente dominado, o objeto perde suas qualidades e, o sujeito, por outro lado, senhor abstrato de um objeto vazio, se torna tão vítima da dominação quanto seus objetos, pois não pode mais retirar deles elementos para se diferenciar e só lhe resta a projeção vazia da sua psicologia que se resumiu a um eu abstrato - representante, no sujeito, da dominação infligida aos objetos.

Contudo, esse não é um diagnóstico terminal da arte e do sujeito, como o senso comum acadêmico algumas vezes atribui a Adorno e seu pessimismo. Adorno está interessado na possibilidade progressiva da arte, no esclarecimento possível pela obra de arte autônoma, e é isso que o leva, acreditamos, a apontar tão contundentemente para aquilo que está negado na tradição. Como vimos, o verdadeiro novo só pode surgir a partir desta.

Nesse sentido Adorno trata, nesse fragmento, de alguns momentos da tradição que apontam para essa possibilidade negada de liberdade:

Até a fase da administração total, o sujeito que contemplava, ouvia ou lia uma obra, devia esquecer-se de si, tornar-se indiferente, desaparecer nela. A identificação que ele realizava era, segundo o ideal, não a de tornar a obra semelhante a si mesmo, mas antes a de se assemelhar à obra. Nisso consistia a sublimação estética; Hegel chamava geralmente a este comportamento de liberdade perante o objecto. (ibid., p. 29) 
Ou seja, em Hegel já havia, pelo menos no ideal, a valorização de uma relação com o objeto que não era mera dominação. O ideal não era tornar toda arte projeção do sujeito, mas o sujeito poder "se assemelhar à obra". Assemelhar-se este que não significa se perder por completo. Mais à frente, Adorno continua:

\footnotetext{
Tão pouco é a arte imagem do sujeito, tão justa é a crítica de Hegel frente à expressão de que o artista deveria ser mais do que a sua obra - não é raro que seja menos, de certa maneira o invólucro vazio do que ele objectiva na coisa -, tão verdade continua a ser que nenhuma obra de arte pode ter êxito a não ser que o sujeito a encha de si mesmo. (ibid., p. 55)
}

À parte das diferenças entre a teoria adorniana e a hegeliana, as quais não nos propomos tratar aqui, é importante salientar que Adorno busca na história da filosofia, com Hegel, por exemplo, e na história da arte, com Beckett, entre outros, momentos em que a arte foi pensada ou realizada não apenas como predominância do momento construtivo enquanto dominação do objeto pelo sujeito. Tendência essa, na filosofia e na arte, que já vimos um pouco também em outros capítulos a propósito de Kant, Schiller e Goethe.

Segundo Adorno, o momento construtivo "pertence ao estrato fundamental do Moderno" (ibid., p. 36). Mas o conceito de construção moderno, apesar de sempre implicar "o primado de procedimentos construtivos em relação à imaginação subjetiva" (ibid., p. 36) não desconsidera a imprevisibilidade do objeto, a qual ele não pode eliminar; o fato de que "toda imaginação possui uma margem de indeterminação" (ibid., p. 51).

“Após a emancipação do sujeito”, diz ele, “já não é possível esquivar-se à mediação da obra por meio dele, sem se recair na coisidade medíocre" (ibid., p. 51). Ou seja, numa sociedade em que o sujeito se afirmou enquanto autônomo, ao menos no ideal - o que há de progressivo no esclarecimento -, prescindir dele seria um retrocesso a uma objetividade ingênua, sinônimo da dominação do homem pela natureza. Para Adorno é preciso não abandonar o sujeito, mas também não pretender o contrário - e impossível: a completa submissão da natureza ao homem, do objeto ao sujeito. A arte autônoma será para ele o modelo de uma relação homem/natureza, sujeito/objeto que não recai em nenhum dos dois extremos, mas mantém a tensão entre ambos: 
A parte subjectiva na obra de arte é em si mesma um fragmento de objectividade. Sem dúvida, o momento mimético inalienável na arte é, segundo a sua substância, um universal, que, no entanto, só é possível atingir através da idiossincrasia indissolúvel do sujeito individual. (ibid., p. 56)

Subjetividade é também objetividade, é o que Adorno diz, de diversos modos, ao longo do livro. Como pode ser depreendido do trecho acima, existe algo de universal que só pode ser alcançado através do particular, algo do objeto que só se faz presente por meio do sujeito. A separação forçada é dominação, para ambos os lados. "Enquanto o particular e o universal divergirem, não há liberdade" (ibid., p. 56), diz ele. ${ }^{60}$

Para Adorno, é na obra de arte moderna que essa liberdade se realiza. E mais, é por

\title{
meio do sujeito que a liberdade se realiza na obra de arte moderna:
}

\begin{abstract}
O totum das forças investidas na obra de arte, aparentemente algo de subjectivo apenas, é a presença potencial do colectivo na obra, em proporção com as forças produtivas disponíveis: contém a mónada sem janelas. É o que se manifesta da maneira mais drástica nas correcções críticas do artista. Em cada melhoramento, a que se vê obrigado, frequentemente em conflito com o que ele considera o primeiro impulso, trabalha ele como agente da sociedade, indiferente quanto à consciência desta. Encarna as forças produtivas sociais sem, ao mesmo tempo, estar necessariamente ligado às censuras ditadas pelas relações de produção, que ele também critica sempre mediante o rigor do métier. (ibid., p. 58, grifo nosso)
\end{abstract}

Como vimos anteriormente, para o material ser moderno é necessário que ele reflita as forças produtivas da sua época. Agora fica evidente que não é apenas o material que faz a obra de arte ser moderna, e sim, também, a mediação feita pelo artista. A radicalidade do moderno acontece quando o artista encarna as forças produtivas no limite que estas proporcionam, e a utopia do moderno, quando ele não se limita às restrições ditadas pelas relações de produção.

60 Faz-se importante salientar aqui a presença do princípio filosófico, central para Adorno, do primado do objeto, evidente em passagens como: "O Novo não constitui nenhuma categoria subjectiva, mas brota forçosamente da própria coisa, que de outro modo não pode tomar consciência de si, livrar-se da heteronomia. O novo obedece à pressão do Antigo que precisa do Novo para se realizar" (ibid., p. 34).

Ou seja, fazer simplesmente qualquer articulação abstrata entre o particular e o universal não significa por si só o Novo. Nesse caso se estaria incorrendo no problema do subjetivismo. Adorno não quer conferir verdade a todo e qualquer proferimento subjetivo. O que ele procura é incluir o subjetivo no cálculo do objetivo de forma a dar sustentação a este. Por isso o conceito de "conteúdo de verdade" é importante, para o julgamento do subjetivo. "O Novo abstracto pode estagnar, transformar-se em algo de 'sempre-semelhante"” (ibid., p. 35). 
Apesar de, em sua constituição histórica, ser sombra da indústria cultural, a arte moderna - moderna em qualquer época - é estruturalmente contrária a esta. Se a indústria cultural representa o extremo das forças produtivas em favor da autopreservação, quando se coopta inclusive a cultura. A arte moderna é aquela que reúne as forças produtivas em seu máximo para o contrário da autopreservação, para a "suspensão dos propósitos diretos”. E, mais importante para nossos objetivos aqui, enquanto a Indústria Cultural cumpre sua função anulando o sujeito, massificando, fica evidente nesse fragmento da Teoria Estética que a arte moderna cumpre a sua por meio do sujeito, necessita do desenvolvimento da subjetividade.

\section{O Conceito de Mímesis}

Mímesis $^{61}$ é um conceito antigo na história da filosofia. Em Tiburi (1995) e em Gagnebin (2005b) podemos encontrar uma breve história da origem desse conceito, em Platão e Aristóteles, e algumas considerações sobre a formulação adorniana à luz desses dois autores.

Segundo Tiburi (1995), nos clássicos, tanto quanto em Adorno, o conceito de mímesis se distancia do significado de sua raiz etimológica latina, na qual indica imitação ou imagem enganadora - sentido muitas vezes atribuído em português, nas raras vezes em que é usado na linguagem corrente -, para se aproximar de uma concepção de produção não pré-determinada. Em Platão, num primeiro momento, o conceito de mímesis se aproxima do de mera imitação. Para ele, existe o mundo das Idéias, onde se encontra a verdade; o mundo sensível, que é o mundo das sombras projetadas pelas idéias verdadeiras, de certo modo imitação destas; e a arte, que é a imitação da imitação e, por isso, estaria mais distante da verdade. A essa concepção de mímesis Adorno se opunha. A autora, contudo, fala de outra concepção de mímesis na obra de Platão que Adorno provavelmente desconhecia, ou não deu atenção, contida em Fedro, mas que está mais próxima à sua. Seria uma mímesis que estaria na obra de arte produzida por meio da loucura ou inspiração dos deuses, o entusiasmo, que não seria mera tentativa de imitação, mas

61 Em português, a palavra grega $\mu$ $\mu$ бıৎ pode ser traduzida por “mímesis" ou “mimese" (GAGNEBIN, 2005b, p. 79). Optamos pelo uso preferencial da primeira por mera padronização. 
uma produção "iluminada”. Essa produção iluminada pelos deuses, por se referir à realidade, podia ao mesmo tempo ser uma espécie de mímesis e trazer alguma verdade.

Gagnebin (2005b) reconhece essas duas tendências em Platão, mas chama a atenção principalmente para outro aspecto da primeira: a ambigüidade de seu poder (formador, acrescentaríamos). Segundo ela a preocupação deste ao tratar do "perigo" da mímesis era mais política que estética. Ele estava preocupado, em A República, com a educação das elites, na época baseada em grande parte na ginástica, mas também na poesia e na música, e, para ele, muito daquilo que era ensinado nas artes não condizia com uma educação justa. Diferentemente da arte hoje, que é considerada mais como expressão subjetiva, na Grécia antiga ela tinha valor por sua fidelidade ao objeto (proximidade da verdade, como vimos), e, segundo Platão, nisso a imagem mimética do artista era inferior a idéia do filósofo. Por um lado então, ela era considerada fraca, ilusória, se comparada à idéia; por outro, devia ser temida, porque tinha uma grande poder de influência na educação, em especial, dos jovens.

No Aristóteles da Metafísica, segundo Tiburi (1995), o conceito de mímesis tem que ser entendido em relação com o conceito de téchne. Tanto téchne quanto mímesis faziam parte de um agir produtivo (póiesis) em oposição a um agir que teria um fim em si mesmo (práxis). Téchne era um saber adquirido, a realização de algo que se tinha capacidade, não era arte. Téchne significava um saber fazer que ligava a experiência do particular ao absoluto do intelecto. A póiesis, porém, continha "elementos da téchne sem limitar-se a ela" (p. 107); isto é, envolvia a realização de uma capacidade latente, mas não tinha a rigidez da téchne:

Ela pode ser considerada uma forma de produção que implica fabricação e criação, um processo que não prevê o produto como algo inalterável e necessário como seria o caso da téchne. O caráter de surpresa do produto leva à consideração da não determinabilidade absoluta do próprio processo. (ibid., p. 107)

Se por um lado pela téchne a imitatio podia se realizar, pela mímesis se realizava a póiesis. Já na Poética, segundo a autora, mímesis continuaria designando um processo de composição que não é cópia ou reprodução de acontecimentos ou coisas pré-determinadas. Nisso a concepção de Aristóteles e Adorno se aproximam, já que para Adorno a mímesis está envolvida na possibilidade do Novo. 
Gagnebin (2005b), por sua vez, com respeito a esse conceito em Aristóteles, destaca novamente seu aspecto mais “formativo”. Segundo ela, este inverteu a preocupação de Platão: ao invés de pensar se a mímesis era prejudicial ou não, se dedicou ao modo como ela deve ocorrer. Para ele, na Poética, o homem aprende desde criança, por imitação ${ }^{62}$; por isso sua proscrição não é posta em questão. Ele desenvolve, nesse livro, sim, diversos meios e maneiras de imitação, nas “artes miméticas”, e quais produzem os efeitos desejados (portanto, uma estética propositiva).

Em sua teoria da metáfora, ainda nessa obra, novamente a função de conhecimento da mímesis é posta em relevo. A metáfora, segundo ele, “é a transposição do nome de uma coisa para outra" (ARISTÓTELES, 1964, p. 304) e “descobrir metáforas apropriadas equivale a ser capaz de perceber relações" (ibid., p. 309).

Essa formulação aristotélica da mímesis e da metáfora terá forte correspondência - saltando alguns séculos - na concepção benjaminiana de mímesis e de semelhança, como também destaca Gagnebin (2005b).

Em seu texto A Capacidade Mimética (1970 [1933-1935]), num primeiro momento, Benjamim fala sobre as similitudes presentes na natureza. Segundo ele:

\footnotetext{
A Natureza engendra similitudes. Basta pensar no mimetismo animal. Contudo, a mais elevada aptidão de produzir similitudes pertence, tipicamente, ao Homem. (p. 49)
}

Uma diferença importante, em relação à Aristóteles, é que para Benjamin essa capacidade mimética tem uma história - aí está sua originalidade, como diz Gagnebin (2005b). Essa capacidade de produzir similitudes do homem tanto não é a mesma no decorrer da história que podemos nos perguntar, continua o autor, mais à frente, se está ocorrendo uma decadência da capacidade mimética ou apenas sua transformação. Ele próprio responde dizendo que apesar dessa capacidade mimética não estar mais presente no homem moderno da forma em que se apresentava anteriormente, como nas correspondências mágicas e mesmo o recurso à Astrologia, ela está presente por meio do idioma, quer da forma mais óbvia, isto é, pelas onomatopéias, quer pela

62 "A tendência para a imitação é instintiva no homem, desde a infância. Neste ponto distingue-se de todos os outros seres, por sua aptidão muito desenvolvida para a imitação. Pela imitação adquire seus primeiros conhecimentos, por ela todos experimentam prazer" (ARISTÓTELES, 1964, p. 265). 
similitude de palavras em diversos idiomas ao redor de um determinado significado, quer pelas imagens inconscientes de quem escreve, que a "grafologia ensinou a descobrir nas escrituras":

\begin{abstract}
A tal ponto o idioma seria a etapa suprema do comportamento mimético e o mais perfeito arquivo de similitudes imateriais: um ambiente ao qual emigraram, sem resíduos, as mais antigas forças de produção e recepção miméticas, até liquidar as forças mágicas. (BENJAMIN, op. cit., p. 52)
\end{abstract}

Esse conflito entre mímesis e magia Gagnebin (2005b) analisa sob a ótica da controvérsia a respeito da herança benjaminiana em Adorno. Como expõe ela, o Adorno da Dialética do Esclarecimento, parece em muitos momentos enfatizar os perigos da mímesis: tanto da "mímesis originária", uma espécie de regressão ao arcaico, o retorno ao amorfo da natureza - que Ulisses enfrenta na Odisséia para se constituir enquanto eu autônomo; quanto uma "mímesis perversa", o enrijecimento do sujeito para enfrentar o sofrimento do mundo. Segundo ela:

Poderíamos afirmar que prevalece, no pensamento de Adorno (e de Horkheimer), na época da Dialética do Esclarecimento, uma certa condenação da mímesis, descrita antes de tudo como um processo social de identificação perversa. Trata-se de uma censura parecida com a censura platônica, a respeito da perda de distância crítica que ocorre no processo mimético entre o sujeito e aquilo a que se identifica. (ibid., p. 91, grifo nosso)

Ainda segundo ela, Adorno, na Dialética Negativa e na Teoria Estética, pagaria uma dívida intelectual à Benjamin, por apresentar uma concepção de mímesis "mais nuançada", "uma mímesis redimida que conseguiria fugir tanto da magia como da regressão" (ibid., p. 101).

Para sustentar essa posição de variação no conceito de mímesis em Adorno como uma divergência, num primeiro momento, e depois como uma conciliação com a concepção benjaminiana, ela lembra a carta de Adorno a Benjamin de 10 de novembro de 1938, em que o primeiro critica a primeira versão do ensaio de Benjamin sobre Baudelaire para a Revista de Pesquisa Social - o qual Adorno recusa e pede reformulação. Segundo ela, todos os motivos que Adorno lista para a reprovação do ensaio, "pensamento mágico remanescente, falta de distanciamento crítico e identificação com o existente, impossibilidade de uma visão totalizante e, em lugar dela, um apego sentimental ao particular, em vez da mediação uma falsa imediaticidade” (ibid., p. 94), eram as mesmas críticas que ele havia feito a respeito da mímesis. Em seguida ainda, ela cita um trecho do texto de Adorno Característica de W. Benjamin, na qual haveria 
uma consideração mais positiva desses traços miméticos; sinalizando, a nosso ver, a passagem, a mudança na concepção de Adorno.

Gostaríamos de enfatizar aqui, porém, uma interpretação possível um pouco diferente da desenvolvida por Gagnebin (2005b), mas deixada aberta por ela em seu trabalho. As partículas relativizadoras presentes em "prevalece" e "uma certa condenação da mímesis" do trecho citado, abre para nós a possibilidade de pensarmos que talvez haja uma mímesis não condenada que só não prevalece na análise desses autores. A esse respeito, para nós, a exceção é tão importante quanto o tom de condenação que, sem dúvida, predomina no texto.

Nossa argumentação caminhará no seguinte sentido: primeiro, de fato, a mímesis, principalmente no Excurso I, sobre Ulisses, é considerada como um retorno ao amorfo e um enrijecimento; porém, como pretendemos mostrar, num segundo momento, essa condenação não se dirige à mímesis, considerada como algo imutável - o que seria fetichizar seu conceito; mas sim à determinada mímesis predominante na história da nossa sociedade. Na Teoria Estética, estando a preocupação justamente voltada para a mímesis não predominante - que inclusive corre o risco de desaparecer, aquela presente na arte autônoma (moderna radical) - seu caráter de reconciliação pôde aparecer com maior vigor. Isso não quer dizer que a conceituação de mímesis já estava na Dialética do Esclarecimento tal qual o encontramos na Teoria Estética, isso seria anular as mais de duas décadas que separam os dois livros. Acreditamos que seu uso do conceito de mímesis se ampliou sim, ficou mais nuançada, sim, pagou uma dívida a Benjamin, sim; porém, que aquilo que está envolvido no conceito de mímesis tal qual o encontramos na Teoria Estética já estava presente na Dialética do Esclarecimento enquanto possibilidade não desenvolvida..$^{63}$

63 Acreditamos também que a teoria da linguagem presente na Dialética do Esclarecimento, tal qual apresentamos nesta parte, para introduzir a concepção de desgaste do material, na Teoria Estética, contém vários dos elementos que estão presentes no conceito de mímesis dessa última obra, apenas não aparecem lá sob este nome. Naquele momento, vimos como para Adorno e Horkheimer a linguagem em nossa sociedade se polarizou em signo, cálculo e dominação da natureza, por um lado (e, portanto, em algo semelhante à mímesis perversa), e em imagem, cópia e confusão com a natureza, por outro (ou seja, em algo semelhante à mímesis originária). Lembramos, porém, que ao final dessa consideração, como vimos, os autores apontam a arte, a "aparência estética", como uma possibilidade de manifestação do todo no particular (e, portanto, em algo semelhante à mímesis reconciliadora). 
Os dois trechos abaixo demonstram o tom explícito da condenação no Excurso I. O primeiro diz:

\footnotetext{
A ratio, que recalca a mimese, não é simplesmente seu contrário. Ela própria é mimese: a mimese do que está morto. O espírito subjetivo que exclui a alma da natureza só domina essa natureza privada da alma imitando sua rigidez e excluindo-se a si mesmo como animista. (ADORNO; HORKHEIMER, 1985, p. 65)
}

E no segundo, a respeito de Ulisses se salvar de Polifemo ao chamar-se de "Ninguém", encontramos: "Na verdade, o sujeito Ulisses renega a própria identidade que o transforma em sujeito e preserva a vida por uma imitação mimética do amorfo" (ibid., p. 71). Em ambos pode-se notar que mímesis se refere a um processo que regride o homem à natureza. O primeiro trecho seria apenas mais uma das dezenas de formas em que os autores inscrevem a dialética entre natureza e razão: a razão queria ser mais que a rigidez da natureza, mas acaba sendo tão rígida quanto a natureza.

Transcreveremos abaixo alguns trechos do capítulo v de Elementos do Anti-Semitismo, parte chave da Dialética do Esclarecimento quando se trata do conceito de mímesis. Dentre eles o leitor provavelmente reconhecerá diversos trechos muito famosos, vastamente citados; e por isso, talvez, mal-interpretados, assim como outros nem tão conhecidos. Nosso objetivo é evitar o desgaste do significado geralmente atribuído aos trechos famosos, que analisados em seu contexto, obviamente, apresentam maior riqueza. Seguem:

\footnotetext{
"Não esqueça de que não suporto você", diz Siegfried a Mime, que solicita seu amor. A velha resposta de todos os anti-semitas é o apelo à idiossincrasia. A emancipação da sociedade relativamente ao anti-semitismo depende da possibilidade de elevar ao conceito o conteúdo da idiossincrasia e de tomar consciência de seu absurdo. A idiossincrasia, porém, apega-se ao particular. O que se considera como natural é o universal, o que se encaixa no contexto funcional da sociedade (ibid., p. 168)
}

No primeiro trecho desse capítulo é dado o motivo pelo qual os autores entrarão no tema da mímesis. Trata-se de combater o argumento anti-semita de repulsa aos judeus por aquilo que se chama de "idiossincrasia". Em outros termos, está aqui retomada a mesma preocupação a respeito de como se evitar o retorno ao domínio da natureza sem cair em barbárie. O fascismo e o anti-semitismo são a barbárie moderna em uma de suas piores faces, e a idiossincrasia é um símbolo da natureza (não dominada), que o fascimo pretendia eliminar. Dentre 
as idiossincrasias, os autores citam suores, cheiros e sons que não possuem uma função social.

Mais à frente um pouco, eles dizem:

O que se considera judeu, aliás, são sempre cifras miméticas: o gesto da mão que argumenta; a entonação cantante com que descreve, independentemente do sentido do juízo proferido, uma imagem animada das coisas e dos sentimentos [...] (ibid., p. 171) ${ }^{64}$

No segundo parágrafo podemos ver como o conceito de mímesis, então evocado, tem realmente mais a ver com um retorno ao amorfo da natureza e um enrijecimento:

Os motivos a que responde a idiossincrasia remetem às origens. Eles produzem momentos da proto-história biológica: sinais de perigo cujo ruído fazia os cabelos se eriçarem e o coração cessar de bater. Na idiossincrasia, determinados órgãos escapam de novo ao domínio do sujeito; independentes, obedecem a estímulos biológicos fundamentais [...] Quando o ser humano quer se tornar como a natureza, ele se enrijece contra ela. A proteção pelo susto é uma forma do mimetismo. Essas reações de contração no homem são esquemas arcaicos da autoconservação: a vida paga o tributo de sua sobrevivência assimilando-se ao que é morto. (ibid., p. 168, grifo nosso)

A idiossincrasia, assim, é uma forma do ser humano de lidar com a ameaça da natureza se transformando em natureza (e se perdendo). O trecho em negrito, mais famoso, portanto representa essa tendência. Mas note o contexto em que a mímesis se aproxima de imitação do que está morto: frente à ameaça da própria morte; não está em questão toda e qualquer situação. Vejamos como continua no parágrafo seguinte, nossa citação mais longa:

Inicialmente, em sua fase mágica, a civilização havia substituído a adaptação orgânica ao outro, isto é, o comportamento propriamente mimético, pela manipulação organizada da mimese e, por fim, na sua fase histórica, pela práxis racional, isto é, pelo trabalho. A mimese incontrolada é proscrita. [...] O rigor com que os dominadores impediram no curso dos séculos a seus próprios descendentes bem como às massas dominadas, a recaída em modos de vida miméticos - começando pela proibição de imagens na religião, passando pela proscrição social dos atores e dos ciganos e chegando, enfim, a uma pedagogia que desacostuma as crianças de serem infantis - é a própria condição da civilização. A educação social e individual reforça nos homens seu comportamento objetivamente enquanto trabalhadores e impede-os de se perderem nas flutuações da natureza ambiente. Toda diversão, todo abandono tem algo de mimetismo. Foi se enrijecendo contra isso que o ego se forjou. É através de sua constituição que se realiza a passagem da mimese refletora para a reflexão controlada. (ibid., pp. 168-169, grifo nosso)

64 Qual não é a semelhança entre essa descrição e a de Goethe a respeito do "aparecer" do nobre no Meister? 
Note que os autores falam que o caminho da civilização foi o de proscrever determinada mímesis, a incontrolada, passando por uma fase de mímesis organizada e chegando ao trabalho, uma "práxis racional". Não se pode, a partir desse trecho, de forma alguma dizer que os autores concordam com a proscrição de toda e qualquer mímesis; pode-se dizer, sim, que na história da nossa sociedade ocorreu uma proscrição da mímesis incontrolada em favor da razão. No decorrer de toda a obra a preocupação dos autores é justamente em denunciar a dominação que a razão instaurou na relação entre os homens, do modo como ela se desenvolveu, de Homero ao fascismo; não pretendiam dizer o que é a razão, ou o que é a mímesis, ontologicamente.

A primeira frase em negrito, muito famosa, não pode, de forma alguma, significar que os autores concordassem com a proscrição de atores ou ciganos, ou que concordassem com uma pedagogia que "desacostuma as crianças de serem infantis"; o que eles pretendiam enfatizar, a nosso ver, é que na história da nossa sociedade essa prescrição ocorreu porque essas figuras - as imagens na religião, os atores, os ciganos e a infância - são opostas ao trabalho, e como o trabalho era considerado a "práxis racional", elas foram, em conseqüência, consideradas irracionais.

Se eles identificam diversão e abandono ao mimetismo, nesse outro trecho muito famoso, eles não querem dizer com isso que as primeiras são características essenciais do segundo. Pelo contrário, note como a diversão e o abandono contêm algo da mímesis justamente porque estes se opõem ao trabalho. E eles dizem ainda, mais à frente, que um dos horrores do fascismo é cooptar para si até aquilo que se lhe opõe. E ainda, se foi assim, se opondo à mímesis, que o ego se formou, foi porque esta formação do ego se deu, em nossa história, por meio do sacrifício - como eles mostram os indícios já na Odisséia. Não que seja assim desde sempre e para sempre. Assimilar a idéia de formação do eu nesses autores à idéia de sacrifício de forma ontológica e não histórica e crítica seria um erro.

Vejamos agora um trecho em que eles retomam o tema da idiossincrasia, mais ao final, para completar o sentido geral do texto analisado:

\footnotetext{
As reações de fuga caoticamente regulares dos animais inferiores, a formigação das multidões de insetos, os gestos convulsivos dos martirizados exibem aquilo que, em nossa pobre vida, apesar de tudo, não se pode dominar inteiramente: o impulso mimético. É na agonia da criatura, no pólo extremo oposto à liberdade, que aflora irresistivelmente a liberdade enquanto determinação contrariada da matéria. É contra isso que se dirige a idiossincrasia que serve de pretexto ao anti-semitismo. (ibid., p. 171, grifo nosso)
} 
Note que os autores não trataram a respeito da mímesis nesse capítulo com o objetivo de falar do poder libertador da arte. Por isso procurar tal coisa seria incongruente - apesar de podermos encontrá-la nas entrelinhas: há algo nas imagens religiosas que não deveria ser proscrito, assim como no caráter de aparência dos atores, na efemeridade e na liberdade frente à propriedade dos ciganos e no lúdico das crianças; todas características presentes também, de certo modo, na arte autônoma. O objetivo deles é mostrar que a idiossincrasia, geralmente usada como argumento contra os judeus, é na verdade algo da ordem da mímesis: natureza, matéria, que não se deixa dominar completamente. Isso não quer dizer que aquilo que está envolvido nessa idéia de mímesis, se ampliado além da mera repetição da natureza, não possa ter um caráter também produtivo, de "produzir semelhanças", como afirma Benjamin. Eles próprios indicam, como vimos, um passo intermediário entre a mímesis originária e o trabalho (a nosso ver, mímesis perversa): “a manipulação organizada da mímesis”. Mas não é na figura do anti-semitismo que o caráter produtivo da mímesis vai se expressar, e por isso não foi, a nosso ver, esse o momento de enfatizá-lo; como não foi num texto como a Indústria Cultural, em que o objetivo era expor a tendência dominante em nossa sociedade de redução da cultura à mercadoria, que os autores enfatizariam o poder libertador do cinema, tal qual fez Benjamin em $A$ Obra de Arte na Época de sua Reprodutibilidade Técnica.

Como já dissemos anteriormente, o pensamento de Adorno se permite sentir tanto medo quanto essa sociedade merece. É difícil dizer isso, mas talvez Benjamin, e não só seu pensamento, não tenha sentido o medo na proporção que este o exigia.

De um livro do teor da Dialética do Esclarecimento e num texto como o Elementos do Anti-Semitismo esperar o mesmo brilho utópico da Teoria Estética é querer uma homogeneidade que o pensamento que se deixar marcar pela história - o pensamento que tem memória - não pode, a nosso ver, conter. Lembremos que sequer a arte moderna podia ser feita e exposta às claras na Alemanha em 1944 (ano de publicação original da Dialética do Esclarecimento), como poderia Adorno falar sobre seu potencial utópico, como o faz na Teoria Estética? Essa não-homogeneidade entre as obras, portanto, não significa contradição, que a Teoria Estética contradiga a Dialética do Esclarecimento, no que tange à mímesis, no caso. Quer dizer que, nessa sociedade, falar do sonho enquanto se vive o horror seria aumentar o horror, pela tentativa 
de apaziguamento do que não pode, nem deve, ser apaziguado. Por outro lado, como veremos, mesmo quando o tema pode ser o sonho (nossa metáfora para a utopia possível na arte), sem com isso ser "um ato bárbaro", o horror ainda acompanha como lembrança do pesadelo vivido, do ainda vivido e do pior ainda possível.

Mas ainda não tratamos de perto a concepção de mímesis presente na Teoria Estética. Para esse objetivo, vejamos primeiro um pouco sobre a relação entre arte e razão nessa obra.

Nela Adorno critica as teorias tradicionais da arte. Segundo ele, estas ou tomam seu objeto, a arte, como uma matéria a ser racionalizada pela lógica tradicional, a teoria racionalista, ou como algo que escapa de qualquer racionalização, a teoria irracionalista. Porém, para ele, ambas estão erradas:

\footnotetext{
A arte é racionalidade, que critica esta sem se lhe subtrair; não é algo de pré-racional ou irracional, como se estivesse antecipadamente condenado à inverdade perante o entrelaçamento de qualquer atividade humana na totalidade social. As teorias racionalista e irracionalista da arte sofrem, pois, um idêntico fracasso. (ADORNO, 2006, p. 70)
}

Adorno diz ainda que, apesar das obras de arte não serem conceituais nem formularem juízos, elas são lógicas (ibid., p. 157). Porém, não se trata apenas da lógica formal, ainda que não abandone esta. A racionalidade presente nas obras de arte não precisam expulsar a lógica formal, como a razão técnica pretende expulsar o que não se submete aos seus parâmetros. Pelo contrário, a lógica formal é um momento da arte, mas não se esgota nela:
A lógica das obras de arte deriva da lógica formal, mas não se identifica com ela: eis o que se revela no fato de as obras - e a arte aproxima-se assim do pensamento dialético - suspenderem a própria logicidade e poderem, no fim, fazer desta suspensão a sua idéia [...] (ibid., p. 159)

Isso que escapa à lógica formal, mas que permanece nas obras de arte, é justamente a mímesis. Na citação abaixo, encontra-se em resumo essa concepção de Adorno sobre a relação entre mímesis e racionalidade:

A arte é refúgio do comportamento mimético. Nela, o sujeito expõe-se, em graus mutáveis da sua autonomia, ao seu outro, dele separado e, no entanto, não inteiramente separado. A sua recusa das práticas mágicas, dos seus antepassados, implica participação na racionalidade. Que ela, algo de mimético, seja possível no seio da racionalidade e se sirva dos seus meios, é uma reação à má racionalidade do mundo racional enquanto administrado. Pois, o 
objectivo de toda a racionalidade, da totalidade dos meios que dominam a natureza, seria o que já não é meio, por conseguinte, algo de não-racional. Precisamente, esta irracionalidade oculta e nega a sociedade capitalista e, em contrapartida, a arte representa a verdade numa dupla acepção: conserva a imagem do seu objectivo obstruída pela racionalidade e convence o estado de coisas existente da sua irracionalidade, da sua absurdidade. (ibid., p. 68)

Como se pode notar nessa passagem, a arte, assim como o esclarecimento, é uma reação ao aprisionamento do mito, mas que não coloca o homem sob uma nova prisão; recusa as práticas mágicas, mas também aponta para a má racionalidade da sociedade administrada. Na Dialética do Esclarecimento, como vimos, essa possibilidade até estava aberta, mas não foi desenvolvida.

Eagleton (1993) num primeiro momento enfatiza a contraposição da mímesis ao conceito na Teoria Estética:

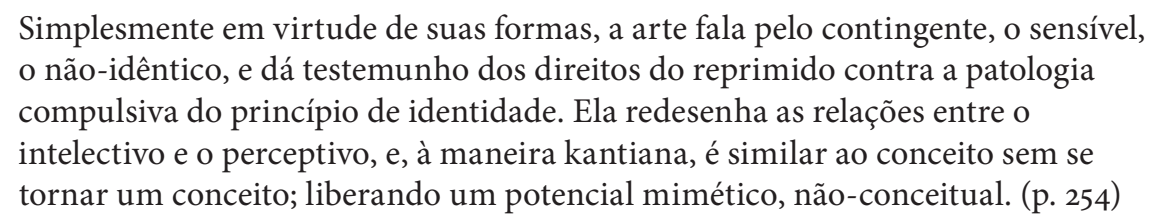

Um pouco mais à frente, porém, ele lembra a importância dos dois momentos, o mimético e o racional/conceitual na obra de arte, para a teoria adorniana:

As obras de arte são divididas contra si mesmas, ao mesmo tempo determinadas e indeterminadas; e isso fica mais óbvio na discrepância entre seus aspectos miméticos (sensível-expressivos) e racionais (construtivo-organizacionais). (ibid., p. 256)

Jay (1988) também diz algo a respeito dessa dialética entre construção e expressão, mas já pondo em relevo o caráter utópico deste, onde pretendíamos chegar:

A preponderância do objeto, que ele [Adorno] defendia em termos filosóficos, estava evidente de maneira mais clara nas obras de arte, irredutíveis às suas origens meramente construtivas e subjetivas. Seu momento mimético é intrinsecamente utópico, pois preserva uma memória da unidade préhistórica entre o homem e a natureza (ela própria recapitulada - talvez - nas memórias da infância do homem civilizado) e é, por conseguinte, uma prefiguração de uma possível restauração dessa condição no futuro. (p. 140)

Isto é, se a filosofia de Adorno é uma tentativa de superar a submissão do objeto ao sujeito, da natureza à razão, presente na história da sociedade e da filosofia, é na sua concepção 
de obra de arte, com seu momento mimético, que encontramos uma utopia dessa reconciliação. Utopia, vale lembrar, pois a obra de arte não pode, por si só, resolver uma contradição da sociedade - como já citamos anteriormente:

\begin{abstract}
A arte, tal como a teoria, não está em condições de realizar a utopia; nem sequer negativamente [...] Pela recusa intransigente da aparência de reconciliação, a arte mantém a utopia no seio do irreconciliado, consciência autêntica de uma época, em que a possibilidade real da utopia - o fato de a terra, segundo o estado das forças produtivas, poder ser aqui e agora o paraíso - se conjuga num ponto extremo com a possibilidade da catástrofe total. (ADORNO, 2006, p. 46)
\end{abstract}

Note a reserva com que Adorno se refere ao caráter utópico da arte, e, portanto, da mímesis reconciliadora: não está em condições (historicamente) de se realizar, nem negativamente. Para nós, tal reserva guarda semelhanças com a do polêmico final do ensaio Crítica Cultural e Sociedade, que comentamos no capítulo 1 da parte i: “escrever um poema após Auschwitz é um ato bárbaro, e isso corrói até mesmo o conhecimento de por que hoje se tornou impossível escrever poemas" (ADORNO, 1998, p. 26). "Não poder se realizar nem negativamente" e "corroer até o conhecimento do por que se tornou impossível", essas duas sentenças de impossibilidade, nos ajudam a pensar novamente por que Adorno teria rejeitado certo otimismo de Benjamin e só tenha atentado à mímesis originária e à mímesis perversa na Dialética do Esclarecimento. Adorno, a nosso ver, não mudou de idéia quanto à mímesis, a mímesis reconciliadora não aparece em seu pensamento, nem na Teoria Estética, com a marca da salvação, como se ele tivesse descoberto, ao final da vida, o caminho. Os aspectos progressivos e emancipatórios da arte sempre estiveram presentes, porém, com essa marca da impossibilidade atual. ${ }^{65}$ Pensando retrospectivamente, com tudo o que vimos neste trabalho, poderíamos dizer que a mímesis originária representa um aspecto do momento da cultura em que esta se reduz à natureza, a mímesis perversa, o momento em que esta se reduz à barbárie, e a mímesis reconciliadora, o momento emancipado da cultura. Mas note, o momento emancipado da cultura ainda não se

65 Para estender ainda um pouco mais a argumentação em torno da polêmica frase sobre a poesia depois de Auschwitz, Adorno, no ensaio A Arte é Alegre? (2001a [1967]) nos diz: "A afirmativa de que após Auschwitz não é mais possível escrever poesia não deve ser cegamente interpretada, mas com certeza depois que Auschwitz se fez possível e que permanece possível no futuro previsível, a alegria despreocupada na arte não é mais concebível. Objetivamente se degenera em cinismo, independentemente de quanto se apóie na bondade e compreensão humanas" (p. 16). 
realizou. Enquanto formação, é só utopia, a realidade é a semiformação; enquanto arte, não é reconciliação, é utopia de reconciliação no seio do irreconciliado. Mesmo na Teoria Estética, paga a dívida a Benjamin, se é que se pode dizer isso, a principal divergência entre eles, a nosso ver, se mantém: qualquer tentativa de realização da utopia - nem que parcialmente - é ideologia.

Lembremos que para Adorno a teoria já é práxis, e a práxis sem teoria é cega; a divergência entre eles - de certa forma, segundo comentadores e biógrafos, uma divergência também entre Adorno e Brecht - é o deslumbramento por determinada práxis emancipatória - muitas vezes marxista - que afirma uma liberdade parcial muito próxima a uma realização da utopia - possível graças a tal práxis, geralmente - enquanto uma consideração teórica, nos termos de Adorno, que remete ao todo, mostraria a marca da impossibilidade dessa realização no ato mesmo de sua enunciação utópica. Na carta de Adorno a Benjamin citada por Gagnebin (2005b) encontramos um trecho em que isso aparece com clareza:

\footnotetext{
A renúncia à teoria afeta a empiria. De um lado, essa renúncia confere à empiria um traço falsamente épico, de outro, tira dos fenômenos seu verdadeiro peso histórico-filosófico, transformando-os em fenômenos experienciados de maneira unicamente subjetiva. (ADORNO apud GAGNEBIN 2005b, p. 93)
}

Um último ponto que gostaríamos de abordar neste capítulo é a contraposição entre a repetição, na razão técnica e na Indústria Cultural, com a noção de Novo, na qual está envolvida a mímesis.

O objetivo da Indústria Cultural é fazer a máquina girar "sem sair do lugar", diz Adorno em seu texto com Horkheimer. "O que é novo na fase da cultura de massas em comparação com a fase do liberalismo avançado é a exclusão do novo" (ADORNO; HORKHEIMER, 1985, p. 126). Para Adorno, o "conteúdo de verdade" das obras de arte está justamente no seu poder negativo, isto é, de tratar sobre o que não é ou existe na realidade imediata: "As obras de arte são negativas a priori em virtude da lei da sua objetivação: causam a morte do que objetivizam ao arrancá-lo à imediatidade da sua vida" (ADORNO, 2006, p. 154).

Nessa negatividade, a mímesis, enquanto racionalidade que não se reduz à intenção, tem um papel essencial. "A verdade do Novo", diz Adorno, “enquanto verdade do já não ocupado, reside na ausência de intenção" (ibid., p. 39). Mais à frente ainda: "A obscuridade do absurdo é a obscuridade antiga do Novo. Deve interpretar-se e não ser substituída pela cla- 
ridade do sentido" (ibid., p.40). Isto é, a totalização sistemática do esclarecimento enrijecido exclui de antemão tudo o que não se encaixa no seu sistema, e, portanto, fica excluída também a possibilidade do novo. O que não ocorre com a mímesis. ${ }^{66}$

\section{Os Conceitos de Construção e Expressão}

Os conceitos de construção e expressão, na Teoria Estética, são importantes para nós, principalmente para entender o papel de mediação do indivíduo na obra de arte e na sociedade.

A construção é o momento tradicionalmente considerado racional, mais aparentado com o conceito e a lógica, o momento em que a intenção do sujeito pretende exercer algum controle sobre o material artístico. No entanto, o contexto da produção artística, por suas características intrínsecas, que inclui a expressão, como veremos adiante, impede que o momento construtivo recaia nos problemas da racionalidade técnica:

\footnotetext{
A construção é, na mônada da obra de arte, com uma onipotência limitada, o representante da lógica e da causalidade, transferida para fora do momento objetivo. Ela é a síntese do diverso a expensas dos momentos qualitativos de que se apodera, bem como do sujeito, o qual pensa nela eliminarse, quando na realidade é ele que a realiza. (ADORNO, 2006, p. 72)
}

Como se pode notar, no momento construtivo da produção artística ocorre uma espécie de subsunção dos particulares a um universal, muito semelhante ao papel do conceito na teoria; contudo, com uma diferença essencial. Adorno continua: "para que a síntese da construção tenha êxito ela deve, apesar de toda a aversão, ser escolhida entre os elementos que em si mesmos jamais obedecem puramente ao que lhes é imposto" (ibid., p. 73). Isto é, o momento

66 Aqui cabe uma ressalva: ser o Novo algo de negativo, que escapa ao sistema do esclarecimento, não quer dizer que haja uma desconsideração do passado. $\mathrm{O}$ verdadeiro Novo não existe sem relação com o passado. Como diz Tiburi (1995): “A arte é o espelho negativo da negatividade do todo social, sem se transformar num positivo. A mímesis não é cópia deste estado, ela é a assimilação, numa associação tensa ao que se lhe opõe. Ela é a mediação entre o antigo e o novo, apresenta o 'horrível' existente e o desconhecido que é a própria promessa. A promessa está contida como negação dentro do existente que deve sempre ser retomado dialeticamente" (p. 127). Ou o próprio Adorno (2006): "A posição da arte atual perante a tradição, que se lhe reprova de muitos modos como perda de tradição, é condicionada pela mudança interna da própria tradição [...] A autoridade do Novo é a da inelutabilidade histórica" (p. 33). 
construtivo que obtém êxito é aquele que não vence ilusoriamente a resistência dos materiais. $\mathrm{O}$ particular permanece com uma especificidade não completamente submetida a um universal.

Expressão, para Adorno, por outro lado, é um conceito de difícil definição porque o que ele abarca é justamente aquilo que escapa ao conceito: “O que é qualitativamente contrário ao conceito só com dificuldade se reduz ao seu conceito" (ADORNO, 2006, p. 131).

Adorno diz isso porque ele considera a expressão como “objetivação do inobjetivo". Como assim? Como é possível uma objetivação do inobjetivo? Se for inobjetivo, já não é, por definição, contrário à objetificação?

Não para a dialética negativa, pensada por Adorno, que não se baseia no princípio de identidade entre a coisa e seu conceito, entre sujeito e objeto (ADORNO, 2008b [1965-1966]). Para a dialética negativa o conceito é sempre mais e menos que a coisa. Mais no sentido de ser separado da coisa, um momento além dela, e menos no sentido de nunca esgotá-la.

Dessa forma, é possível uma objetivação do inobjetivo, desde que se tenha em mente que o inobjetivo nunca será completamente objetivado:

\footnotetext{
A expressão estética é objetivação do inobjetivo de tal sorte que, pela sua objetivação, se torna num segundo inobjetivo, no que se exprime a partir do artefato e não como imitação do sujeito. (ADORNO, 2006, p. 131)
}

Isto é, a objetivação não se realiza por completo na expressão, a objetivação do inobjetivo cria um segundo inobjetivo, mas já mediatizado. E é a mediação que ganhará expressão na obra, não as intenções do artista:

\footnotetext{
Mais do que tais sentimentos [do artista], o seu modelo é a expressão de coisas e situações extra-artísticas. Os processos e as funções históricas encontram-se nelas já sedimentados e exprimem-se. (ibid., p. 131)
}

Com isso pode-se ter uma idéia do que é esse inobjetivo que é objetivado na arte: história sedimentada. Esse é o cerne da concepção adorniana de arte como historiografia inconsciente. A arte remete ao extra-artístico, ao que está além de si, isto é, ao todo, e que esse todo é histórico. Agora, como isso pode estar sedimentado na arte? A resposta, seguindo Adorno, será: através da linguagem, se pensarmos a linguagem não como comunicação, mas como a própria substância da expressão: 
A substância da expressão é o caráter lingüístico da arte, fundamentalmente diverso da linguagem como seu médium [...] a arte esforça-se pela transformação da linguagem comunicativa numa linguagem mimética. (ibid., p. 132)

Adorno vai assinalar como esse caráter mimético da linguagem faz com que a expressão da obra de arte não seja apenas expressão da intenção do sujeito, isto é, não se confunde com o momento construtivo, e sim é expressão da história sedimentada em todos os materiais. Em outras palavras, se o subjetivo do indivíduo é expressão do objetivo da sociedade, o subjetivo da arte não é expressão do subjetivo do sujeito, como se poderia pensar, mas outra forma de expressão do objetivo da sociedade no sujeito.

A expressão é o olhar das obras de arte. A sua linguagem, na relação com a linguagem significativa, é algo de mais antigo, mas não recuperado: como se as obras de arte, ao modelarem-se pela sua estrutura sobre o sujeito, repetissem o modo do seu nascimento e da sua libertação. Têm expressão, não quando comunicam o sujeito, mas ao estremecerem com a história primigénia da subjetividade, da "animação"; o trêmulo de toda a forma, enquanto seu substituto, é intolerável, paráfrase da afinidade da obra de arte com o sujeito. Ela subsiste porque aquela história primigénia sobrevive no sujeito que, em toda a história, recomeça sempre desde o início. Só o sujeito vale como instrumento da expressão embora também ele, que se julga imediato, seja algo de mediatizado. Mesmo quando a expressão se assemelha ao sujeito, quando as emoções são subjetivas, são ao mesmo tempo impessoais, inserem-se na integração do eu e não imergem nela. A expressão das obras de arte é o não-subjetivo no sujeito, menos sua expressão do que sua cópia [...] (ibid., p. 133, grifo nosso)

Novamente, arte e indivíduo são expressão, no sentido adorniano, da sociedade e da história no sujeito, e não, como se poderia pensar, a arte como uma expressão do indivíduo. ${ }^{67}$ A conjunção dialética, operada pelo sujeito, entre a racionalidade tradicional e a mímesis, entre o momento construtivo e o expressivo na produção artística, é o novo modelo de racionalidade possível. Acreditamos que esse é o resultado obtido por Adorno, na Teoria Esté-

67 Isso não significa, porém, que no momento expressivo, por sua relação com o todo, o sujeito seja menos sujeito, pelo contrário. Para Adorno esse momento de mediação entre o particular e o todo, em que o sujeito é instrumento da expressão, é o seu momento por excelência: "O instante do auto-esquecimento, no qual o sujeito submerge na linguagem, não consiste no sacrifício do sujeito ao Ser. Não é um instante de violência, nem sequer de violência contra o sujeito, mas um instante de reconciliação: a linguagem fala por si mesma apenas quando deixa de falar como algo alheio e se torna a própria voz do sujeito. Onde o eu se esquece na linguagem, ali ele está inteiramente presente; senão a linguagem, convertida em abracadabra sacralizado, sucumbiria à reificação, como ocorre no discurso comunicativo" (ADORNO, 2OO3i, p. 75). 
tica, ao buscar um "conceito positivo de esclarecimento", problema por ele colocado, junto com Horkheimer, na Dialética do Esclarecimento.

Nesse sentido, este trabalho se junta à posição que enxerga na Teoria Estética uma tentativa de resposta aos problemas lançados na obra de 1944.

Wiggershaus, por exemplo, importante historiador da Escola de Frankfurt, se insere nessa linha e reconhece, além disso, essa relação entre mímesis e subjetividade como um dos momentos mais importantes da obra de Adorno:

O ponto alto da filosofia adorniana da arte e de sua continuação de Dialektik der Aufklärung também em $\ddot{T} T$ vinha a ser isso: as obras de arte não passavam de pré-historias da subjetividade que tentavam realizar o Aufklärung de maneira esclarecida. (WIGGERSHAUs, 2002, p. 680)

E em Duarte (1993), comentando uma passagem da Teoria Estética, encontramos uma constatação semelhante:

Nisso [a comunidade entre arte e natureza] as obras de arte realizam o que, já na Dialética do Esclarecimento, fora exigido como necessária auto-reflexão do esclarecimento: a "rememoração da natureza do sujeito". (p. 144)

\section{Conteúdo de Verdade, Arte como Escrita e Historiografia Inconsciente}

A duas idéias muito freqüentes na Teoria Estética sobre as quais tratamos indiretamente até aqui daremos agora uma atenção especial.

O conceito de conteúdo de verdade em Adorno, remete - mais uma vez - a Benjamin. Já no ensaio As Afinidades Eletivas de Goethe, publicado em duas partes nos anos de $1924 \mathrm{e}$ 1925, ele faz a distinção entre conteúdo de verdade e conteúdo factual. Mazzari, responsável pela edição brasileira, comentando sobre os termos originais em alemão, nos diz: 
Os termos "teor de verdade" e "teor factual" correspondem no original a Warheitsgehalt e Sachgehalt. O substantivo masculino Gehalt pode ser traduzido também por "conteúdo", mas este corresponde mais propriamente a Inhalt, o conteúdo objetivo - assunto, argumento, acontecimentos - de uma obra literária. Gehalt, por sua vez, conota também a visão de mundo ou os valores envolvidos na obra, razão pela qual optou-se aqui por “teor”. (BENJAMIN, 2009a, p. 12, nota do tradutor)

Apesar da preferência de Mazzari pela tradução de Gehalt por “teor” - que estará presente nas citações do ensaio sobre Goethe -, já que na maioria das outras publicações em português de autores da Teoria Crítica, inclusive na Teoria Estética, optou-se pela tradução por “conteúdo", seguimos essa convenção no restante das ocasiões.

Para Benjamin, na obra citada, o conteúdo factual seria aquele mais evidente, que chama a atenção à primeira vista na obra, que está em "primeiro plano", sobre o qual se pode fazer um comentário; por outro lado o conteúdo de verdade seria aquele oculto, que precisa ser desvelado através da crítica - inseparável da história das obras.

Em Origem do Drama Trágico Alemão, já tratado aqui diversas vezes, o conteúdo de verdade também aparece como tarefa crítica e com base na história:

\footnotetext{
Mas a estrutura e o pormenor têm sempre, afinal, uma carga histórica. O objecto da crítica filosófica é o de mostrar que a função da forma artística - e o drama trágico é uma dessas formas - consiste em transformar em conteúdos de verdade filosóficos os conteúdos históricos objectivos que estão na base de toda a obra de arte significativa. (BENJAMIN, 2004, p. 263)
}

Isso que pode parecer evidente, depois de tudo o que tratamos aqui, na época, para Benjamin, representava demarcar uma nova forma de fazer crítica de arte, a partir do materialismo histórico. Depreende-se de sua argumentação nesses dois livros que tanto boa parte da crítica, na época, não conseguia ir além do conteúdo objetivo das obras, por meio do comentário, quanto a crítica filosófica de até então geralmente não chegava ao cerne da própria obra. Por exemplo, a respeito da filosofia de Schiller, da qual tratamos um pouco, ele afirma: "A teoria schilleriana do impulso lúdico visava a gênese e os efeitos da arte, mas não a estrutura das suas obras" (ibid., p. 76). Essa consideração histórica e da estrutura das obras, Benjamin já reconhecia, na Origem do Drama, em Lukács; mas como vimos em A Idéia de História Natural, de Adorno, ainda estava impregnada de uma certa concepção teológica da história. 
Na Teoria Estética o conceito de conteúdo de verdade assume grande importância, em especial no fragmento a ele dedicado: Caráter enigmático, conteúdo de verdade e metafísica (pp. 138-157 da edição portuguesa). É a partir dessa formulação que podemos unir muitos dos fios aparentemente soltos até agora: em resumo, o conteúdo de verdade pode ser conhecido mediatamente através da crítica, num deciframento da história inscrita na obra na forma de uma aparência enigmática, isto é, não de forma puramente conceitual, mas numa dialética entre mímesis e racionalidade, construção e expressão.

Um pouco antes desse fragmento já encontramos um trecho esclarecedor, que ao mesmo tempo nos fala sobre o papel da filosofia na crítica:

\footnotetext{
O espírito das obras artísticas não é conceito, mas é por seu intermédio que se tornam comensuráveis ao conceito. A crítica, ao isolar o espírito a partir das configurações das obras, ao confrontar entre si os momentos e com o espírito que nelas aparece, transforma-se em sua verdade para além da configuração estética. Eis porque a crítica é necessária às obras. No espírito das obras, ela reconhece o seu conteúdo de verdade ou dele o distingue. Só neste acto, e não através de uma filosofia da arte que a esta ditaria o que o seu espírito devia ser, é que a arte e a filosofia convergem. (ibid., p. 107)
}

Note que a crítica é necessária às obras para retirá-las de sua imanência. A filosofia não é necessária enquanto prescrição estética, mas enquanto maneira de entrar em contato com uma verdade que está inscrita na configuração, na estrutura da obra, mas que só se torna verdade, de fato, ao transpor a configuração imanente por meio dos conceitos.

"A imagem enigmática da arte é a configuração da mimese e da racionalidade" (ibid., p. 148), Adorno nos diz no fragmento sobre o conteúdo de verdade. Tal imagem é indissociável de seu caráter de aparência, que na Teoria Estética está relacionada principalmente à aparição do espírito objetivo nas obras de arte, como já vimos sobre o conceito de expressão. Porém, essa aparição do espírito objetivo não é transparente e necessita da crítica:

As obras de arte são enigmáticas enquanto fisionomia de um espírito objectivo, que nunca é auto-transparente no instante da sua aparição [...] a necessidade de interpretação das obras enquanto necessidade da elaboração do seu conteúdo de verdade é o estigma da sua insuficiência constitutiva. (ibid., p. 149)

Essa insuficiência constitutiva não é um defeito, mas seu caráter de autenticidade, estreitamente ligado à marca de impossibilidade da utopia na arte que justamente lhe confere 
valor. Toda obra de arte "autêntica", para Adorno, propõe a solução do seu "enigma insolúvel” (ibid., p. 148), isto é, ela pede pela interpretação ${ }^{68}$ ao mesmo tempo em que não pretende que se chegue a nenhum veredito absoluto e claro. Seu conteúdo de verdade está na sua negatividade, em retirar o que objetivam da imediaticidade da vida sem dominá-lo, como o faz a religião:

\begin{abstract}
Nenhuma obra de arte existente ou que aparece domina positivamente o não-ente. Tal facto distingue as obras de arte dos símbolos religiosos, que pretendem possuir a transcendência da presença imediata no fenômeno. $\mathrm{O}$ não-ente nas obras de arte é uma constelação do ente. (ibid., p. 157)
\end{abstract}

Note o teor de reconciliação possível nessa concepção. A obra de arte não domina o não-ente, como que dizendo: "está vendo isso - o objeto fetiche - isso é o transcendente". O transcendente, o não-ente, surge como uma constelação do ente. O não-ente não é nem pretensamente reduzido ao ente, nem está em completa oposição a este.

O caráter enigmático da obra de arte nos ajuda a entender também em que termos, para Adorno, a obra de arte é uma escrita. Ele nos diz que, em sua época, “debates suscitados por páginas de Klee" haviam tornado o conceito écriture relevante (ibid., p. 145). E assim continuam até hoje, a nosso ver. Mas Adorno pontua duas características desse caráter escritural que não podem ser ignoradas: primeiro, essa escrita não é clara e evidente, no sentido de poder ser reduzida a uma abstração, sempre permanece algo de enigmático; segundo, essa escrita se dá a despeito da linguagem escrita, se dá pela configuração, mesmo nas obras de arte que não aparecem, à primeira vista, como escrita:

\footnotetext{
Esta categoria da modernidade [écriture] arroja como projector luz sobre o passado; todas as obras de arte são uma escrita, e não apenas as que aparecem como tais, e certamente hieroglíficas, para as quais se perdeu o código e para cujo conteúdo contribui acima de tudo a ausência de tal código. As obras de arte são linguagem só enquanto escrita. (ibid., p. 145)
}

Essa segunda pontuação ficará mais clara no décimo fragmento: Em direção a uma teoria da obra de arte (pp. 199-255 da edição portuguesa), quando Adorno trata um pouco sobre a dialética vivida, pela obra de arte, entre ser efêmera e ser coisa.

68 "A genuína experiência estética deve tornar-se filosofia ou, então não existe." (ibid., p. 152) 
Em momentos anteriores, na Teoria Estética, Adorno já havia trabalho a questão da objetivação na arte. Esse “objetivar”, transformar em coisa, da arte não pode ser confundido com a fetichização, pura e simples, apesar desta ter seu papel. Segundo Adorno, a reificação é essencial às obras de arte, mas não se reduz a ela: "A obra de arte é ao mesmo tempo processo e instante. A sua objectivação, condição da autonomia estética, é também petrificação" (ibid., p. 119). ${ }^{69}$

No fragmento em questão ele dirá algo a isso complementar: "A reflexão deve tanto compreender o carácter feiticista, sancionar por assim dizer a expressão da sua objectividade, como analisá-la criticamente" (ibid., p. 208). O caráter de escritura da arte é justamente o que permite essa objetivação sem recair em fetichismo. Analisemos a seguir o trecho abaixo:

\begin{abstract}
A dinâmica, que toda a obra de arte em si encerra, é o seu elemento lingüístico. Um dos paradoxos das obras é que, dinâmicas em si mesmas, elas são em geral fixadas, ao passo que é através da fixação que as obras de arte se objectivam. Assim como, quanto mais insistentemente se observam, tanto mais paradoxais se tornam: toda obra é um sistema de contradição. O seu próprio devir não poderia representar-se sem fixação; as improvisações costumam simplesmente justapor-se e, por assim dizer, ocupar o mesmo lugar. A escrita e a notação, vistas do exterior, desconcertam pelo paradoxo de um existente que, segundo o seu sentido, é devir. Os impulsos miméticos que movem a obra de arte integramse nela e de novo a desintegram, são uma expressão provisoriamente privada de linguagem. Tornam-se linguagem mediante a sua objectivação enquanto arte. Salvação da natureza, a objectivação protesta contra a efemeridade da arte. A obra de arte torna-se semelhante à linguagem no devir da ligação dos seus elementos, sintaxe sem palavras mesmo nas obras lingüísticas. O que elas dizem não é o que dizem as suas palavras. Na linguagem sem intenções, os impulsos miméticos transmitem-se ao todo que os sintetiza. (ibid., pp. 208-209)
\end{abstract}

Nele pode-se perceber como, para Adorno, uma mímesis originária seria um retorno à natureza, pura dinâmica, puro movimento, mas que a mímesis da obra de arte, ao atuar como uma linguagem, dá a fixação necessária sem ser fixação excessiva - aquela que impede o devir e transforma tudo em mera repetição, a mímesis perversa. Essa escrita, que nada mais é do que a escrita da história, se dá mesmo nas obras sem palavras (nosso "segundo ponto", abordado

69 Mesmo as artes "efêmeras", que precisam da execução, como o teatro e a música, estão de certa forma impregnadas do caráter coisal, no caso, ao texto escrito e à partitura, ele diz. Podemos pensar que não é diferente nas manifestações contemporâneas que levam à arte ao extremo de sua efemeridade, como nos happenings; ainda assim essas manifestações estão impregnadas de caráter coisal: fotos, catálogos de exposições, resenhas, críticas etc. - é dessa forma que elas permanecem na cultura e participam da tradição - negando-a a princípio, sendo incorporadas a ela, num segundo momento - e não apenas se perderem, passado o instante de sua realização. 
há pouco) porque se dá, sempre, sem palavras, mesmo nas obras feitas com palavras, como a literatura; ela se dá pela sintaxe dos seus elementos, pela sua constelação.

A arte enquanto historiografia inconsciente, por sua vez, é algo que, a partir de tudo o que vimos, parece auto-evidente, mas um equívoco pode estar à espreita - o historismo:

\begin{abstract}
O momento histórico é constitutivo nas obras de arte; as obras autênticas são as que se entregam sem reservas ao conteúdo material histórico da sua época e sem a pretensão sobre ela. São a historiografia inconsciente de si mesma da sua época; o que não é o último factor de sua mediação relativamente ao conhecimento. É isso precisamente que as torna incomensuráveis ao historismo que, em vez de seguir o seu próprio conteúdo histórico, as reduz à história que lhes é exterior. (ibid., p. 207)
\end{abstract}

Isto é, não basta uma análise histórica das obras de arte para se dizer que se chegou ao seu conteúdo de verdade, assim como, para quem produz a obra, não adianta ter a pretensão de contar a história de sua época na obra produzida. A história está presente nos materiais de forma inconsciente, e só dificilmente se consegue levá-la à consciência. Muitas vezes o que acontece é o historismo, um traçado de correlações vazias, do ponto de vista do material, e apenas meramente contingentes historicamente.

Por outro lado, isso não significa um irracionalismo da parte de Adorno, que as obras de arte sejam historiografias inconscientes da sociedade não quer dizer que a consciência não tem um papel imprescindível.

Um pouco mais à frente, no fragmento citado, encontramos um trecho muito sintético sobre a relação entre conteúdo de verdade, arte como historiografia inconsciente e a consciência mais progressista exigida pela obra de arte moderna radical, tal como vimos no capítulo 2 desta parte. Vejamos:

O conteúdo de verdade das obras de arte, de que depende finalmente a sua qualidade, é histórico até ao mais profundo de si mesmo. A sua relação à história não é relativa de tal modo que ele próprio e a qualidade das obras de arte variariam apenas em função do tempo. Sem dúvida, uma tal variação tem lugar e as obras de arte de qualidade podem, por exemplo, tornar-se caducas ao longo da história. No entanto, o conteúdo de verdade e a qualidade não cabem ao historismo. A história é imanente às obras, não é nenhum destino exterior, nenhuma avaliação flutuante. O conteúdo de verdade torna-se histórico ao objectivar-se na obra a consciência

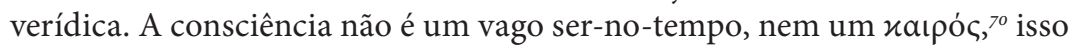

70 Segundo o índice de palavras não traduzidas dessa edição, a expressão citada, de origem grega, significa “ocasião propícia, tempo próprio, momento crítico” (ibid., p. 292). 
justificaria o curso do mundo, que não é o desabrochamento da verdade. Depois que o potencial de liberdade cresceu, a consciência verídica é antes a consciência mais progressista das contradições no horizonte da sua possível reconciliação. $O$ critério da consciência mais progressista é o estado das forças produtivas na obra a que, na época da sua reflexividade constitutiva, pertence também a posição que adopta no interior da sociedade. Enquanto materialização da consciência mais progressista, que encerra a crítica produtiva da situação estética e extra-estética dada, o conteúdo de verdade das obras de arte é historiografia inconsciente, ligado ao que até hoje se manteve constantemente no estado latente. (ibid., p. 217)

Note como a consciência - e, portanto, a consciência do sujeito - possui um papel essencial: o conteúdo de verdade torna-se histórico ao se objetivar, na obra, em consciência verídica. O que estava latente no material só pode ser considerado história inconsciente em face de uma consciência, mas não de qualquer consciência, e sim daquela que se objetivou na obra, e que o fez enquanto consciência mais progressista, isto é, como pode-se perceber mais uma vez, aquela que é ao mesmo tempo radical e utópica, expressa a contradição no seu mais alto grau, mas justamente para se manter fiel à possibilidade de reconciliação, hoje impossível.

Em outro momento, mais à frente, essa relação entre conteúdo de verdade e consciência mais progressista aparece ligada à questão da emancipação e com um exemplo elucidativo:

Em última análise, o progresso não é só um progresso do domínio do material e da espiritualização, mas também um progresso do espírito no sentido hegeliano, da consciência da sua liberdade. Pode-se discutir indefinidamente se o domínio do material em Beethoven é um progresso em relação ao de Bach; um e outro dominam perfeitamente o material segundo dimensões diferentes. A questão sobre qual dos dois é maior é ociosa; mas não a constatação de que a voz da maioridade do sujeito, emancipação do mito e reconciliação com este, portanto, o conteúdo de verdade, evoluiu mais em Beethoven do que em Bach. (ibid., pp. 239-240)

Não nos interessa aqui, nem é de nossa competência, analisar a validade do juízo de Adorno a respeito do conteúdo de verdade ser mais progressista em Beethoven do que em Bach. Acreditamos mesmo que Adorno pode ter se equivocado a respeito de determinados juízos específicos sem que com isso sua teoria se invalide - mas isso seria matéria para outro estudo. $\mathrm{O}$ que nos interessa aqui é destacar que as obras de arte não são iguais; o que não significa, necessariamente, que são melhores umas que as outras. E sim que elas são objetificações da consciência em graus diferentes de progresso em relação ao conteúdo de verdade.

Um último aspecto que gostaríamos de destacar a respeito da arte enquanto historiografia inconsciente é a questão do sofrimento. Já vimos anteriormente que todo documento 
de cultura foi até hoje um documento de barbárie, vimos também que os materiais guardam a história do homem e que até hoje essa história não se desvencilhou da servidão e da dominação, em face da qual a arte é uma promessa de felicidade que não pode ser realizada, que não pode realizar a utopia a preço de se tornar ideologia. Essa temática, presente em toda a Teoria Estética, para não dizer em toda a obra de Adorno, é justamente aquela com a qual ele termina esta última obra, termo simbólico no mais alto nível. Vejamos:

\begin{abstract}
Também não convém visualizar a forma da arte numa sociedade transformada. Sem dúvida, esta é uma terceira coisa em relação à arte do passado e à arte actual, mas valia mais desejar que um dia melhor a arte desapareça do que ela esquecer o sofrimento, que é a sua expressão e na qual a forma tem a sua substância. Esse sofrimento é o conteúdo humano, que a servidão falsifica em positividade. Se, conforme ao desejo, a arte futura se tornasse de novo positiva, a suspeita de uma persistência real da negatividade seria aguda; ela é-o constantemente, porque a regressão ameaça sem cessar, e a liberdade, que no entanto seria a liberdade a respeito do princípio de propriedade, não pode ser possuída. Mas que seria a arte enquanto historiografia, se ela se desembaraçasse da memória do sofrimento acumulado? (ibid., p. 291, grifo nosso)
\end{abstract}

O legado dessa última frase é o que tentaremos adquirir nas nossas reflexões a respeito de arte, educação e formação, no próximo capítulo.

\title{
6 Arte, Educação e Formação
}

Quando se pensa na relação da arte com a educação e com a formação, muitas vezes pode-se pensar em qual seria a sua função nessas. No último fragmento do corpo da obra, na Teoria Estética, chamado Sociedade (pp. 253-291 da edição portuguesa), uma das questões que Adorno "responde", se tivéssemos essa pergunta em mente ao lê-lo, é essa da função da arte. Primeiro ele descreve um quadro a nós muito familiar:

Com a organização progressiva de todos os domínios culturais cresce o apetite de assinalar à arte, teórica e até mesmo praticamente, o seu lugar na sociedade; inumeráveis mesas redondas e simpósios giram em torno deste tema. (ibid., p. 280)

Quantos simpósios e mesas redondas com esse tema nós já não participamos ou, ao menos, ouvimos falar a respeito? Porém, ele continua mais à frente: 
A soberania do olhar topográfico, que localiza os fenômenos para comprovar a sua função e o seu direito à existência, é uma usurpação. Ignora a dialéctica da qualidade estética e da sociedade funcional. O acento põe-se a priori, se não no efeito ideológico, pelo menos no carácter consumível da arte, e é dispensado de tudo aquilo em que a reflexão social da arte poderia hoje ter o seu objecto: é decidido de antemão de um modo conformista. (ibid., p. 28o)

Ou seja, para Adorno, querer assinalar a função da arte na sociedade já é, desde o princípio, desconsiderar suas verdadeiras qualidades. O conteúdo de verdade das obras, como vimos, se realiza através de sua crítica, que faz emergir o que nelas há de revolucionário sem recair em mais dominação, mais barbárie, permanecendo sempre algo de não-dominado, de enigmático, e por isso dificilmente ele se deixaria reduzir a um lugar bem delimitado na conta do burguês, do estadista ou do cientista positivista.

Querer atribuir uma função educadora ou formadora à arte é semelhante a querer dar a arte o lugar do prazer. Como vimos, o prazer pode até estar presente na arte, mas isso não é sua função. Função tem o sucedâneo da arte na Indústria Cultural, que prepara o corpo, no descanso, para o momento de trabalho. Da mesma forma, a arte forma sim, mas forma lá onde não esperamos que ela forme.

A formação, Adorno nos diz, é por essência antinômica:

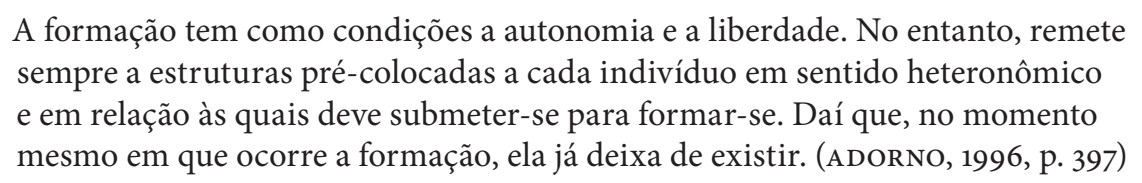

Obviamente não é tão simples assim. Adorno expõe essa antinomia para que não esqueçamos como se deu hegemonicamente a formação até hoje: o homem submetendo-se ao seu outro, para nele transformar-se; isto por meio ou da sua submissão à natureza - mímesis originária -, ou a outro homem - mímesis perversa. A arte, por outro lado, e a mímesis a ela inerente, abre a possibilidade de que essa relação do homem com o seu outro não seja de mera submissão e identificação. Lembremos o seguinte trecho já citado a respeito da mímesis:

A arte é refúgio do comportamento mimético. Nela, o sujeito expõese, em graus mutáveis da sua autonomia, ao seu outro, dele separado, no entanto, não inteiramente separado. (ADORNO, 2006, p. 68) 
Tanto na Teoria da Semiformação quanto na Teoria Estética, Adorno enfatiza o caráter narcisista da relação atual com a arte, contrário a essa exposição ao outro. Do primeiro destacaremos o diagnóstico:

\begin{abstract}
É subjetivo o mecanismo que fomenta o prestígio de uma formação cultural que já não se acolhe e que, em geral, só obtém uma atualidade por malograda identificação. A semicultura colocou ao alcance de todos esse clube exclusivista. O narcisismo coletivo alimentado por tal mecanismo faz com que as pessoas compensem a consciência de sua impotência social consciência que penetra até em suas constelações instintivas individuais - e, ao mesmo tempo, atenuem a sensação de culpa por não serem nem fazer o que, em seu próprio conceito, deveriam ser e fazer. (id., 1996, pp. 404-405)
\end{abstract}

Do segundo, a crítica:

\begin{abstract}
A arte é assim, para o sujeito, metamorfoseado no que ela é em si, portavoz histórico da natureza oprimida e, em última análise, crítica perante o princípio do eu, agente interno da opressão. A experiência subjectiva oposta ao eu é um momento da verdade objectiva da arte. Quem, em contrapartida, vive as obras de arte, referindo-as a si, não as vive; o que passa por vivência é um sucedâneo culturalmente provocado. (id., 2006, p. 275)
\end{abstract}

Ou seja, como já vimos sob outros aspectos no decorrer deste trabalho, o narcisismo não é o momento máximo da subjetividade, mas sua degeneração. Ao tratar as obras como apenas algo que deve servir a si, o sujeito se empobrece e barra a verdadeira experiência que o contato com o outro - que envolve, sempre, um perder-se no outro - pode possibilitar.

Se, como vimos no capítulo sobre formação e educação, a primeira é um processo mais amplo que a segunda, possibilitada e impossibilitada, ao mesmo tempo, por determinações históricas e sociais que ultrapassam em muito as intenções pedagógicas, por outro lado vimos também que Adorno, nem por isso, abandonou a educação enquanto campo fértil de transformações, principalmente na primeira infância, e nos adultos, enquanto consciência cultural geral. Embora Adorno, como nos diz Batista (1997, 2002), não nos ofereça um modelo de pedagogia, nem uma pedagogia da arte, não podemos dizer que em diversos momentos ele não tenha feito asserções bastante diretas a respeito de métodos pedagógicos, apenas não os constituiu em sistema - esta jamais seria sua intenção. Se até o momento, nesta parte IV, nos dedicamos especialmente às suas considerações na Teoria Estética, onde pouco aparece o caráter pedagógico que não negativamente, faremos agora um retorno a uma obra pouquíssimo co- 
nhecida dele chamada Analytical Study of the NBC Music Appreciation Hour, onde encontramos alguns dos temas desenvolvidos na Teoria Estética ou na Teoria da Semiformação, já no final da década de 30, tratados por uma ótica "mais pedagógica" - o que não quer dizer "mais prática"; prática já é enquanto teoria.

Não é nosso objetivo, nem temos competência, para ir fundo no que tange à especificidade da estética musical, por isso tentaremos nos concentrar em aspectos mais gerais e nos exemplos dados pelo próprio Adorno.

Carone (2003) nos dá alguns dados sobre essa obra, que não chegou a ser publicada por Adorno:

Quando Theodor W. Adorno foi contratado por Paul F. Lazarsfeld para participar da seção musical do "Princeton Radio Research Project" em 1938, realizou um estudo analítico do já consagrado programa de educação de música clássica pelo rádio, "The NBC Music Appreciation Hour Conducted by Walter Damrosch". O artigo resultante desse estudo ficou nos arquivos da Universidade de Columbia (New York) até 1994, quando foi redescoberto por musicólogos e publicado, depois de 55 anos, na revista The Musical Quarterly. (p. 478)

Não ter sido publicada, Carone ainda nos diz, se explica pelo fato de não ter agradado a ninguém sua crítica radical a um programa que era considerado, na época, sem fins lucrativos e comercias. Mas, como ela conclui:

[...] a análise de Adorno permitiu mostrar como ela [a iniciativa educacional da $\mathrm{NBC}$ ] obedeceu aos interesses dos monopólios comerciais no setor musical, pela via da transmissão radiofônica. Não aparecia como "business" porque não contava com patrocínio comercial e implicava em enormes despesas da NBC. Mas tinha todas as marcas da indústria do entretenimento, de modo que a intenção educativa foi solapada por uma intenção comercial não confessada: a de vender a música clássica, além de vender uma imagem promocional da rede NBC. (ibid., pp. 491-492)

É bem conhecida também a discordância entre Adorno e Lazarsfeld ${ }^{71}$ a respeito do que deveria ser o trabalho no Princeton Radio Research Project. Este último foi provavelmente o responsável pelo engavetamento do trabalho.

Vejamos um trecho da descrição que Carone nos faz desse programa educativo da NBC e dos seus objetivos: 


\begin{abstract}
A rigor, o programa visava popularizar a música clássica e ao mesmo tempo fazer de Damrosch (que Adorno e os europeus não tinham em alta conta como músico) "o principal embaixador americano da compreensão e da apreciação musicais" (Horowitz, 1993) para as crianças e jovens das escolas norte-americanas. Obviamente, era dedicado ao ensino complementar da "apreciação da música" através do meio de comunicação mais abrangente, popular e ubíquo de que se tinha notícia: o rádio. Era acompanhado por 4 manuais dirigidos aos estudantes (Student's Worksheets) e um guia dos professores de música (Teacher's Guide), publicados pela editora da Universidade de Columbia em 1939. (ibid., p. 479)
\end{abstract}

Apesar do objetivo do estudo de Adorno, no contexto da Radio Research, ser o de mostrar como uma das falhas do programa é não fazer uma crítica ao próprio rádio, nos concentraremos aqui nos motivos pelos quais Adorno afirma que o programa da NBC (ao qual a partir de agora nos referiremos por $M A H$ ) falhou musical e pedagogicamente, o que envolve a transmissão da música pelo rádio, mas não apenas. Muito do que ele critica em relação a transmissão pelo rádio, e ao programa da NBC, acreditamos que se repete em muitas das formas atuais, tanto de relação com as obras de arte, quanto do ensino de arte.

Segundo ele o programa leva o estudante a "um mundo musical fictício governado por nomes de personalidades, rótulos estilísticos e valores pré-digeridos que não podem possibilitar a 'experiência"” (ADORNO, 1994a, p. 326)72, e o rádio, por ser "uma empreitada econômica numa cultura da propriedade" promove no ouvinte uma relação "inocente e entusiástica para com qualquer material oferecido" (ibid., loc. cit.). Isto é, não promove uma verdadeira experiência.

Um dos procedimentos desse programa, e o primeiro a ser criticado por Adorno, é o de ensinar música de "fora para dentro", isto é, de buscar elementos externos para ajudar na compreensão da obra. Segundo Adorno:

O procedimento que parte de fora, isto é, de coisas externas ao mundo da música ou de determinado conteúdo descritivo de música, para dentro da música, a saber, para sua estrutura e seu 'sentido', recomenda a si mesmo que se mantenha em acordo com o que é conhecido da psicologia da criança. Mas desde que, na música, as ferramentas visíveis não têm valor em si mesmas, e desde que, na música, só há "conteúdo" no sentido imaginário acidentalmente, tal conteúdo, mesmo em muitos exemplos óbvios das músicas do "programa”, permanece de alguma forma ambíguo e arbitrário, a estrutura essencial da música oferece dura resistência ao procedimento recomendável psicologicamente. Apenas o mais desenvolvido tato pode combinar em um só tempo as aspirações psicológicas programáticas com os requisitos estruturais da linguagem musical. A Music Appreciation Hour, a despeito de algum comentários compensatórios, falhou completamente 
em alcançar uma combinação equilibrada, por sua quase exclusiva ênfase em objetos externos. Isso pode ser em parte explicado pelo fato da ascendência musical do Dr. Damrosch vir da tradição 'neudeutsche' e sofrer do desenfreado exagero de lado descritivo da música típico de tal escola. (ibid., p. 329)

O que, basicamente, Adorno critica nesse procedimento é que ele não atinge o cerne das obras - seu conteúdo de verdade, nos termos da Teoria Estética. Aquilo de externo à música que serviria de introdução à estrutura das obras, e que ao mesmo tempo respeitaria a "psicologia” do estudante, acaba não saindo desses objetos externos, que guardam apenas uma relação arbitrária com a obra.

Adorno dá diversos exemplos do fracasso desse procedimento. O primeiro se encontra na primeira parte do programa (Série A), na qual o estudante é encorajado a reconhecer os instrumentos por suas diversas personalidades. Ora, Adorno nos diz, na música séria muitas vezes o som individual do instrumento não possui valor intrínseco em si, mas em função de sua estrutura no todo. Ensinar o estudante a reconhecer a "personalidade" do instrumento é "distrair pedagogicamente do que é importante para o que é subsidiário" (ibid., p. 330). Adorno nos diz que a criança pode ficar contente toda vez que a flauta acidentalmente faz um solo e começar a ouvir Haydn - e em suas músicas os instrumentos não falam como personalidades - esperando o momento em que haverá a entrada das flautas, dos violinos etc. e perder a música em si mesma. Ele chama esse tipo de audição de technique-minded, isto é, voltada para a técnica: "Essa atitude, que substitui os meios pelo fim, é o paradigma do que podemos apropriadamente designar por atitude fetichista com a música" (ibid., p. 331). A esse respeito ele ainda fala que essa audição técnica representa um perigo grave para o "desenvolvimento psicológico" das "pessoas jovens" e que “a educação deveria se esforçar para contrabalancear a hegemonia da técnica” (ibid., loc. cit.).

Outro exemplo é a respeito da segunda parte do programa (Série B), em que o estudante é encorajado a reconhecer a música por seus "temas", o que, mais uma vez distrai a atenção do todo para a parte. Vejamos o que ele nos diz:

\footnotetext{
A noção de tema não deve desaparecer, mas deveria receber seu lugar de direito e assim ganhar seu verdadeiro significado. Os pupilos deveriam ser levados a sentir, embora em termos diferentes, que um tema é um tipo de "afirmação" que obtém seu significado apenas no interior de uma unidade funcional e não como algo em si mesmo. Se este caráter do tema for demonstrado pela análise de uma melodia folk, e se as similaridades entre a estrutura de uma melodia folk e uma forma musical desenvolvida forem clarificadas, poder-se-ia facilmente
} 


\begin{abstract}
mostrar a diferença entre elas. Isto é, poder-se-ia demonstrar que a unidade da melodia folk é uma unidade "imediata”, uma unidade em que as partes não se dissociam umas das outras, ao passo que a unidade da música séria é uma unidade articulada que consiste na função de partes marcadas pelo contraste ou, ao menos, pela diferença. Isso explicaria o fato de que enquanto o tema na sinfonia tem fundamentalmente o mesmo papel que o motivo tem na música folk, o tema sinfônico se torna evidente por si só, o que não é verdade no caso do motivo na melodia folk. Em outras palavras, a análise deveria levar a um postulado duplo: que ao ouvir música articulada deve-se ser capaz de distinguir as partes, e construir a partir delas uma unidade, por estar consciente de sua inter-relação funcional. Tudo isso soa complicado quando explicado em palavras apenas, mas pode ser feito claro para qualquer criança pelo uso de exemplos concretos. (ibid., p. 332)
\end{abstract}

Note que Adorno não está lançando um juízo final a respeito de toda e qualquer música folk, em todos os seus aspectos; ele diz algo bem específico: a música folk (pelo menos aquela que ele provavelmente tinha contato, pelo rádio) tinha uma unidade melódica mais imediata que a música séria (o que nós chamamos comumente de "música erudita"), isto é, só se capta a unidade da música séria ao ser capaz de distinguir suas diversas partes e entender o sentido de sua configuração, enquanto a música folk a que Adorno tinha acesso, assim como a maioria da população americana, sua unidade era evidente por uma não distinção entre as partes, em outras palavras, uma repetição. Caso se prove que há casos de música folk em que a melodia tem sua unidade numa constelação de suas partes ou que nem toda música séria a tem, isso não invalida a proposta de Adorno, pois é calcada em exemplos concretos, não em mera transmissão de um juízo abstrato.

Pode-se ainda, pensando em outra objeção possível, dizer que a música folk ou outras formas de "música popular" não podem ser adequadamente analisadas pelos mesmos critérios da música erudita, que sua inovação, sua radicalidade se encontra em outro aspecto do material e da configuração da obra, ainda assim o argumento de Adorno não é invalidado, já que os materiais contam a história do homem, e essa história é repleta de contradições. Ainda que se argumente que o folk, ao qual Adorno se referia, possuiu radicalidade a partir de outros critérios, ainda assim, do ponto de vista da unidade melódica, a consciência então objetificada é menos progressista neste aspecto.

Importante também lembrar é que, para Adorno, se o objetivo da $M A H$ era levar o conhecimento da música erudita, os critérios desta é que deveriam ser os norteadores, enquanto o que ele testemunhava eram os critérios da Indústria Cultural (ainda não com essa nomen- 
clatura) - diversão, reconhecimento imediato, culto a nomes de prestígio - transpostos para a música erudita.

Nessa parte do seu estudo, Adorno ainda dá mais dois exemplos. O terceiro exemplo ainda diz respeito à Série B. Num determinado momento desta série, chamado "Animais na Música", é apresentado às crianças a Cavalgada das Valquírias de Wagner, e as crianças são instadas a associarem os determinados instrumentos a determinadas imagens: a trompa e o violoncelo ao tropel, as flautas ao relinchar, as trombetas e os trombones ao canto de guerra das donzelas, e as cordas ao seu choro. Vejamos um trecho da crítica de Adorno:

Há um enclausuramento da imaginação da criança que é forçada, a
todo custo, a associar certas imagens prescritas à música. A ingenuidade
artificial de tal aproximação é mais provável que aborreça a criança
do que a agrade, e não será surpreendente se as crianças mais alertas
e menos conformadas chamem qualquer tentativa desse tipo, de
interpretar a música, de estúpidos termos circenses. (ibid., p. 334)

Note o caráter coercitivo da relação da criança com a obra e a artificialidade do procedimento pedagógico descrito. Este subestima a inteligência das crianças e, portanto, além de tentar impor uma interpretação exterior arbitrária à música, pode causar no estudante uma perda de confiança no que é ensinado.

O último exemplo dado por Adorno para criticar esse procedimento "de fora para dentro" está na série D, em que fala sobre a vida e a época do compositor. Lá, segundo ele, quando se fala de Bach é feita uma série de associações fortuitas e externas que ligam este a um castelo e a Wagner, dando uma aura heróica, ao compositor: "Eles todos dormem no mesmo panteão de grandeza, indiscriminadamente adorados de fora" (ibid., p. 335). Recepção problemática sobre a qual Adorno fala melhor em outro momento.

Ainda nessa primeira parte do estudo encontramos uma crítica mais estritamente pedagógica. Num primeiro momento ele critica a forma obscura como são passados alguns conceitos e dá o exemplo da introdução da Série B, em que se diz que a matéria da música é um "movimento ideal", "assim como a forma e as cores são para a pintura, a arquitetura e a escultura”. Segundo ele, essa explicação é muito geral e obscura, e é difícil para uma criança e para um adolescente entender o que se quer dizer com isso. Corre-se o risco até desse "ideal" ser ligado ao sentido de "perfeito", ao modelo platônico, e causar confusão: 
A questão prática para a pedagogia é mostrar precisamente de que modo isso ocorre, como tentamos esboçar acima, ao invés de simplesmente dizer que isso ocorre. (ibid., p. 335)

Um pouco mais à frente ele critica a ordem das explicações na Série C. Elas aparecem como se a história da música fosse uma progressão do mais simples para o mais complexo, o que não é verdadeiro. Adorno cita o caso da fuga, uma das formas mais complexas, que é apresentada às crianças logo nas primeiras lições, quando elas ainda não têm condições de entender tal forma musical. Resultado: "leva as crianças a um saber acadêmico sobre a música, não uma real compreensão" (ibid., p. 337).

Essa mesma concepção linear, do mais simples para o mais complexo, Adorno critica também na Série D, que fala dos compositores. Segundo essa lógica, Bach está logo no começo, o que é um absurdo. Bach é muito mais difícil de compreender do que muitos dos compositores que vêm depois dele, e isso pode prejudicar a aprendizagem. Adorno sugere que se comece, por exemplo, por Schubert; suas peças, com contrastes marcados nos temas, são mais fáceis para ilustrar o esqueleto que estrutura a música. Adorno sugere uma linha de mais fácil compreensão, segundo ele, passando de Schubert para Haydn, desse para Mozart, de Mozart para Beethoven, e desse para os outros. Mas sempre a partir de argumentos concretos relacionados à estrutura das obras.

Em seguida, Adorno faz uma série de críticas a respeito de confusões e impropriedades especificamente musicais na $M A H$, como, por exemplo, confundir duas formas musicais, apresentando-as indiferenciadamente. Sobre isso não entraremos em detalhes; para nossos objetivos basta destacar que Adorno atribui esses erros a uma utilização tanto de um material pouco característico daquilo que se quer explicar, quanto de explicações pouco específicas (ibid., p. 341).

A segunda parte do trabalho de Adorno é ainda mais interessante, para nossos objetivos. Nela ele analisa como o programa da NBC promove uma "pseudocultura musical" (musical pseudo-culture). Como o texto foi escrito em inglês, Adorno provavelmente tinha em mente a palavra Halbbildung, em alemão, a mesma que no decorrer deste trabalho traduzimos por semiformação. Como vimos, a palavra Bildung pode ser traduzida em português por formação ou por cultura. Nesse texto podemos supor que o mesmo se aplica a escolha de Adorno pelo termo culture, em inglês, por isso usaremos os termos semiformação e pseudocultura indistintamente. 
Adorno, nessa segunda parte, desenvolve a tese de que a estrutura da $M A H$, com os problemas pedagógicos e as inconsistências musicais por ele apresentados promove, em especial, três aspectos da semiformação (que na Dialética do Esclarecimento também aparecerão a respeito da Indústria Cultural): 1. a ênfase no "prazer" e na "diversão" no contato com a obra de arte, que aparece no $M A H$ sob a noção de "apreciação"; 2. a promoção de uma identificação superficial com a música; e 3. o culto aos "grandes gênios" do passado correlato ao conformismo no presente.

O primeiro faz parte da chamada "estética do efeito", à qual o próprio Adorno remete a Aristóteles. O grande problema dessa estética, que considera antes de tudo os efeitos da obra de arte no receptor, e não sua estrutura, não é que esta não deva causar um efeito, pelo contrário, quando se atinge uma real compreensão da estrutura da obra de arte muitas vezes essa coincide com um determinado efeito; porém, no $M A H$, o contato com a música pelo estudante é incentivado a começar pelo efeito para se chegar ao efeito, a estrutura da obra mesma fica em segundo plano. Adorno diz: “é mais essencial para o ouvinte satisfazer [to please] a sinfonia de Beethoven do que esta satisfazê-lo" (ibid., p. 355); o que significa que é mais importante o ouvinte compreender o que está envolvido numa sinfonia de Beethoven, "satisfaça" a abrangência necessária, a compreensão das diversas partes e sua relação com o todo, do que o fato dessa sinfonia gerar ou não prazer, ainda que provavelmente produza tal prazer.

Adorno ainda fala sobre a promoção, pelo $M A H$ de uma "audição culinária", "atomística" e de um "hedonismo musical”, todas características da "regressão da audição" muito bem tratadas por ele em diversos outros escritos sobre música e que dizem respeito basicamente, e respectivamente, a: escuta ligada ao prazer $^{73}$; imediatista e sem consideração pela estrutura; e auto-referida, narcisista; todas características já trabalhadas por nós neste trabalho, no que tange à obra de arte em geral, e não apenas a musical. O que nos interessa especialmente, nesse texto, é a recomendação pedagógica explícita de Adorno: “Boa educação musical postula o

73 Outra característica citada por Adorno, ligada a esta, é a naturalização da beleza: “Por detrás desse discurso de 'nós' que deveríamos nos satisfazer está uma idéia velada de 'sentimento musical natural'. Esse 'sentimento musical natural' não existe. É apenas o verniz de atitudes historicamente mutáveis, e o que alguém hoje pode chamar de musicalmente 'natural' é na verdade um resíduo de convenções do passado" (ibid., p. 255). Sobre essa relação entre beleza natural e história, há um fragmento na Teoria Estética, chamado Beleza Natural (pp. 77-95 da edição portuguesa) em que Adorno se dedica a esse tema, discutindo, em especial, com as concepções de Kant e Hegel. 
respeito pela obra, evidenciado pela preocupação do ouvinte com o senso musical per se" (ibid., p. 358). O que poderíamos estender para: a educação de arte deve postular o respeito pela obra, em si, e não pelo efeito que ela causa.

Sobre a promoção de uma identificação superficial com a música, pela MAH, Adorno nos diz que o programa está mais interessado em que os estudantes aprendam a identificar e nomear os compositores, assim como identificar suas épocas históricas de modo que o contato real com a obra fica também em segundo plano. O principal, nesse sistema, é que o estudante adquira conhecimentos sobre músicas como se fossem "propriedades", isto é, como se, a partir do momento que ele pudesse reconhecer imediatamente a obra e o compositor, estas lhe pertencessem. Esse tipo de relação, nos diz ele, é menos uma apreciação da música do que uma apreciação da "ordem mecânica" e uma submissão à autoridade. Assim o conhecimento da obra se reduz àquilo a que o conhecimento é reduzido: a "informação". Disso podemos depreender que a educação de arte não é informação sobre arte.

Sobre o culto aos "grandes gênios" e o conformismo correlato, ${ }^{74}$ Adorno nos diz que a $M A H$, por diversas vezes exalta os compositores como "heróis", como "gigantes", sem diferenciar uns dos outros, como se todos estivessem no mesmo patamar celeste. E quando usa referências para essa "grandeza" cita o sucesso e o reconhecimento financeiro. O outro lado dessa exaltação indiferenciada dos gênios do passado é que a música moderna é ignorada pelo programa, e elementos desta, como a dissonância, são tratados negativamente, sem nem sequer dar explicações a respeito. Adorno chama isso de "babiteria" (babbittry, em referência ao personagem George Babbitt, de Sinclair Lewis), que significa basicamente uma atitude de conformismo perante a própria mediocridade e um julgamento de tudo a partir de critérios quantitativos, geralmente em dinheiro. Isto é, toda a potencialidade crítica da obra de arte moderna é ignorada e o que há de crítico nas obras do passado é apagado em sua consideração indiferenciada (concepção museal de cultura), promovendo assim, o conformismo. Contra isso, Adorno faz uma sugestão pedagógica que gostaríamos de destacar:

74 Último aspecto do texto em questão que consideraremos aqui, há ainda outros, aos quais não nos dedicaremos, como a questão dos métodos de avaliação, no quais, grosso modo, se repetirão os problemas já apresentados. 
Seria uma boa idéia abrir um programa nesse curso, falando aos alunos: "Vocês ouviram que Beethoven é um grande compositor e essa conversa provavelmente os irrita. No mínimo, gostariam de saber por que ele é grande quando comparado a outros compositores. É porque colocou um coro final na Nona Sinfonia, ou porque a ópera Fidélio é baseada em idéias humanitárias? É porque introduziu a expressão subjetiva como um elemento básico da música? Esta última é certamente a sua contribuição mais notável mas se desejarmos compreender a música de Beethoven, devemos saber como a expressão subjetiva pode ser percebida dentro da obra de Beethoven e como, nos seus elementos específicos, essa música é superior a outra música”. Então, poderemos comparar a música de Beethoven com a de seus contemporâneos. Apontaremos para os elementos específicos de sua técnica, tal como a economia estrita de suas composições que utiliza cada pedaço do material temático e não apresenta nada que não tenha uma função dentro do todo. (ibid., p. 362) 75

O que podemos depreender dessa consideração é que, para Adorno, uma educação de arte exige uma crítica da arte. Uma obra não é apenas boa, ela é boa por um motivo. Vimos na Teoria Estética que Adorno, sobre Beethoven e Bach, nos diz que ambos dominam o material de formas diferentes, mas que, no que tange ao progresso objetificado da consciência, o primeiro estaria à frente do segundo. Aqui, como se pode notar, ele fala algo semelhante. No mesmo texto ele diz que Beethoven, Lully, Corelli e mesmo Händel, que têm obras na $M A H$, são grandes por motivos diferentes, o primeiro pelo motivo já dado e os outros por representarem adequadamente seu tempo. Segundo ele: "O termo grandeza, no caso desses dois tipos, tem um significado completamente diferente e requer diferentes interpretações” (ibid., p. 362).

O que Adorno não diz diretamente então, mas fica subentendido na sua crítica ao conformismo para nós, e que achamos de suma importância destacar (fazendo, com isso, um retorno ao que já trabalhamos da Teoria Estética - e, portanto, talvez, Adorno ainda não pudesse ter formulado desta maneira no artigo sobre a $M A H$ ), é que uma crítica da arte na educação de arte vai levar o estudante necessariamente à dimensão do sofrimento inerente à toda obra de arte moderna radical. Lembremos que a categoria do moderno não é temporal, mas filosófico-histórica, e que Beethoven era moderno e radical em seu tempo, levou os procedimentos e os materiais que ele tinha a sua disposição ao seu máximo, e isso se objetificou numa obra que expressa uma possibilidade de subjetividade - vislumbrada em sua época também no ideal de formação de Schiller, por exemplo, não realizada. O fato dessa possibilidade não ter se realizado, do sujeito emancipado permanecer uma figura do ideal burguês (quer como 
utopia, quer como consolação), levará o estudante a se perguntar o porquê disso. Assim como a se perguntar o porquê da dissonância na música moderna, das imagens sombrias e distorcidas na pintura expressionista, do non-sense e desesperança no teatro de Beckett, da claustrofobia e persecutoriedade nos romances de Kafka.

Apontar para esse conteúdo de verdade - que é sempre um conteúdo crítico -, na educação de arte, é atentar para o sofrimento de uma forma que a atitude conformista e adaptacionista hegemônica nesta sociedade presente, sem dúvida, na educação que ela promove, dificilmente aceitará; mas que deve ser feito. ${ }^{76}$

Para nós, a partir de nossa leitura de Adorno, uma educação de arte não deve se esquivar de nada do que está envolvido na verdadeira experiência com as obras de arte e na consideração de seu conteúdo de verdade, obtido por meio da crítica. Se não o faz - se enfatiza o prazer, o sucesso, a posse ou, como se pode notar por vezes, quando no currículo escolar, uma utilidade para a compreensão de outras disciplinas, "mais importantes", tudo o que não for especificamente da configuração artística ou dela extraído pela crítica filosófico-histórica - é porque não é ensino de arte, mas um sucedâneo adaptacionista.

76 Segundo Gagnebin (2009b), a dimensão do sofrimento central na estética de Adorno não faz com que esta se torne uma ética da compaixão, mas da resistência: "É claro que Adorno se inscreve numa tradição filosófica, à qual Schopenhauer também pertence, que não situa a raiz do ético na construção de um consenso racional, mas sim num impulso quase físico-mimético, neste sentido pré-verbal e pré-lógico, um impulso em direção aquele que sofre. [...] Se o sofrimento ocupa um lugar essencial na reflexão de Adorno, sua ética não será uma ética da compaixão, mas muito mais, nas pegadas do melhor anticristianismo nietzschiano (e a dialética marxista), uma ética da resistência" (p. 94). 


\section{Considerações Finais}


Benjamin, em Sobre Alguns Temas em Baudelaire (2000), nos fala que a grande obra de Proust, Em Busca do Tempo Perdido, foi a tentativa de reproduzir artificialmente a experiência enquanto duração (de Bergson) nas condições atuais, nas quais não é mais possível se realizar "naturalmente" (p. 105).

Se Adorno não aposta tanto quanto Benjamin nas exceções, se para ele a liberdade do particular nunca pôde, até hoje, se desvencilhar da marca do universal não-livre, não é na posição de Benjamin perante Proust que os dois autores da Teoria Crítica discordariam, a nosso ver. Tanto Benjamin manteve em sua análise da experiência em Proust a marca do todo, quanto Adorno não negou o impulso conciliatório presente no imenso esforço deste. Como pode se ver na seguinte passagem:

O paradoxo de toda a arte moderna é adquirir ao mesmo tempo o que
rejeita, da mesma maneira que o início da Recherche de Proust, com o arranjo
elaboradíssimo, introduz no livro sem o ruflar da câmara escura, sem o
caleidoscópio do narrador omnisciente: renuncia ao encantamento mágico e só
assim o realiza. A experiência estética é a de algo que o espírito não teria nem
do mundo nem de si mesmo, a possibilidade prometida pela sua impossibilidade.
A arte é a promessa de felicidade que se quebra. (ADORNo, 2006, p. 157)

Sem pretender nos aprofundar em uma discussão em torno da posição desses dois autores a respeito de Proust e sua obra, gostaríamos de destacar uma passagem de Em Busca do Tempo Perdido que contradiz uma asserção do narrador do livro, asserção esta também negada por Benjamin em seu ensaio, por outros motivos, e que nos servirá de mote neste momento final. 
É muito conhecida a passagem do primeiro livro, No Caminho de Swann - a mesma por nós referida anteriormente neste trabalho, a propósito do conceito de experiência em Benjamin e sua relação com a memória involuntária de Proust - em que o protagonista recupera memórias perdidas ao sentir o sabor de uma madeleine mergulhada no chá. Neste livro o narrador/protagonista conta, num primeiro momento, uma história da sua infância em Combray - o trecho que analisaremos - e diz, em seguida, que se não fosse a memória involuntária conseguida "por acaso" com o bolinho talvez nunca tivesse tido uma memória "viva" do seu passado:

Na verdade, poderia responder, a quem me perguntasse, que Combray compreendia outras coisas mais e existia em outras horas. Mas como o que eu então recordasse me seria fornecido unicamente pela memória voluntária da inteligência, e como as informações que ela nos dá sobre o passado não conservam nada deste, nunca me teria lembrado de pensar no restante de Combray. Na verdade, tudo isso estava morto para mim. (PROUST, 2006, p. 70)

Sobre o caráter casual do encontro com o objeto que desperta a memória involuntária, encontramos:

É assim com nosso passado. Trabalho perdido procurar evocá-lo, todos os esforços
de nossa inteligência permanecem inúteis. Está ele oculto, fora de seu domínio e
de seu alcance, em algum objeto material (na sensação que nos daria esse objeto
material) que nós nem suspeitamos. Esse objeto, só do acaso depende que o
encontremos antes de morrer, ou que não o encontremos nunca. (ibid., p. 71 )

Esses dois trechos são citados por Benjamin, em seu ensaio, a fim de expor a posição de Proust, ${ }^{77}$ posição tal que ele resume da seguinte forma:

Nas reflexões que introduzem o termo [memória involuntária], Proust fala
da forma precária como se apresentou em sua lembrança, durante muitos
anos, a cidade de Combray, onde, afinal, havia transcorrido uma parte de
sua infância. Até aquela tarde, em que o sabor da madeleine (espécie de bolo
pequeno) o houvesse transportado de volta aos velhos tempos - sabor a que
se reportará, então, freqüentemente -, Proust estaria limitado àquilo que lhe
proporcionava uma memória sujeita aos apelos da atenção. Esta seria a mémoire
voluntaire, a memória voluntária; e as informações sobre o passado, por ela
transmitidas, não guardam nenhum traço dele. (BENJAMIN, 200o, p. 106)

Porém, Benjamin não concorda plenamente com Proust, para ele, depender do acaso é dar um caráter por demais privado a um fenômeno social. "As inquietações de nossa vida

77 Isso se assumirmos a identidade entre este e o narrador, o que não podemos fazer sem reservas, já que se trata de uma obra de ficção. 
interior" segundo ele, só adquirem esse caráter privado "depois que se reduziram as chances dos fatos exteriores se integrarem à nossa experiência" (ibid., p. 106) e então parte para sua análise da degeneração da experiência na sociedade moderna, por nós já abordada, em termos gerais, na parte III deste trabalho.

O trecho que queremos destacar aqui é para, além desse ponto colocado por Benjamin, mostrar como a separação proustiana entre memória voluntária e involuntária pode ser matizada em um aspecto; se Benjamin mostrou que a memória involuntária não é obra do acaso, mas da história, pretendemos mostrar como a memória voluntária, ou pelo menos a do protagonista, no Em Busca do Tempo Perdido, não é assim tão vazia, nem assim tão voluntária, mas também contém a história, e não é qualquer história, é a história inconsciente do sofrimento e da possibilidade de reconciliação.

Aquilo que o protagonista se lembrava voluntariamente de sua infância, que ele conta no início do livro, era o sofrimento que passava todos os dias ao final da tarde, quando sabia que teria de ficar sozinho no quarto de dormir e esperava ansiosamente pelo momento em que sua mãe viria lhe dar o beijo de boa noite. O personagem Swann, que ganhará grande importância no livro, nesse momento representa apenas um a mais de sofrimento: nas noites de visita de Swann, por vezes sua mãe não vinha beijá-lo, o que era terrível para ele. Num desses dias de visita de Swann, o protagonista inventa uma série de peripécias para conseguir, de algum modo, a tão desejada presença da mãe. Ao procurá-la, no corredor, como era proibido de fazer, seu pai o surpreende com ela, e diferentemente do feito nas outras vezes e do então esperado, não recebeu uma bronca, mas uma mostra, da parte de seu pai, de um reconhecimento de seu sofrimento. Vejamos uma parte do tal trecho:

\footnotetext{
Mamãe passou aquela noite em meu quarto; no momento em que acabava de cometer uma falta tão grande que esperava ser obrigado a deixar a casa, meus pais me concediam mais do que eu nunca teria obtido deles como recompensa de uma boa ação. E até na hora em que se manifestava por aquele ato de graça, o procedimento de meu pai para comigo conservava esse quê de arbitrário e imerecido que o caracterizava e que provinha de que em geral sua atitude obedecia antes as circunstâncias fortuitas que a um plano premeditado. Talvez até aquilo a que eu chamava sua severidade, quando me mandava deitar, merecesse menos esse nome do que a severidade de minha mãe ou de minha avó, pois a natureza de meu pai, mais diferente da minha em certos pontos do que a natureza delas, provavelmente não havia adivinhado até então o quanto eu sofria todas as noites, coisa que minha mãe e minha avó muito bem sabiam: mas as duas me amavam o bastante para não consentir que me fosse poupado o sofrimento, pois queriam
} 
ensinar-me a dominá-lo, a fim de diminuir minha sensibilidade nervosa e fortalecer minha vontade. Quanto a meu pai, cuja afeição por mim era de outra espécie, não sei se teria ele tal coragem: logo que compreendeu que eu sofria, dissera a minha mãe: "Vai consolá-lo". Mamãe ficou aquela noite em meu quarto e, como para não prejudicar com nenhum remorso aquelas horas tão diferentes das que eu tinha o direito de esperar, quando Françoise, ao compreender que se passava alguma coisa de extraordinário, ao ver mamãe sentada junto de mim, com a minha mão na sua e deixando-me chorar sem ralhar-me, perguntou-lhe: "mas senhora, que tem o patrãozinho para chorar assim?", mamãe lhe responde: "Nem ele mesmo o sabe, Françoise, está nervoso; prepare-me depressa a cama grande e vá deitar-se". Assim, pela primeira vez, minha tristeza não era mais considerada como uma falta punível, mas como um mal involuntário que acabavam de reconhecer oficialmente, como um estado nervoso de que eu não era responsável: fora-me dado o consolo de não ter de mesclar nenhum escrúpulo à amargura de minhas lágrimas, podia chorar sem pecado. Também não era pequeno meu orgulho perante Françoise, por aquela reviravolta das coisas humanas, que, uma hora depois que mamãe se recusara a subir a meu quarto e me mandara desdenhosamente dizer que dormisse, me elevava assim à dignidade de adulto, fazendo-me atingir de súbito uma espécie de puberdade do sofrimento, de emancipação das lágrimas. (PROUST, op. cit., pp. 62-63)

Note que o reconhecimento do sofrimento, mesmo que interpretado como, de certa forma, arbitrário, por parte de seu pai e, conseqüentemente, das outras pessoas da casa, foi uma espécie de passagem para a vida adulta, uma espécie de emancipação para o protagonista. Essa descrição de Proust sobre a necessidade de dominar o sofrimento, enquanto criança, e a relativização dessa dominação, com o reconhecimento do sofrimento, ou seja, reconciliação, motivo emancipador, é para nós muito semelhante a menoridade e a possibilidade de emancipação da sociedade burguesa - ainda não conseguida, mas já vislumbrada.

Um dos motivos pelos quais escolhemos começar nossa consideração final pela análise de um trecho de uma obra é justamente porque analisá-la, para nós, é exercitar a função da crítica, como vimos até aqui, com base em Adorno, de realizar o conteúdo de verdade da obra enquanto transcendência da configuração da obra. Para nós, o relato de Proust, ainda que fictício, conta uma história particular através de uma configuração que se repete no todo da sociedade: a participação na cultura envolver, até hoje, uma renúncia da natureza instintiva, e uma adaptação às convenções sociais que recalca o sofrimento, que "engole o choro". Por outro lado, aponta também para uma saída: quando esse sofrimento é reconhecido por outro, quando se é dado o direito de sofrer, de "sentir tanto medo quanto essa realidade o exige", esse é o começo da autonomia, o momento em que a palavra passa de um representante da cultura - repressivo - para um membro particular da cultura: expressivo, enquanto representante da natureza da qual a cultura pretendia se separar; e construtivo, enquanto, ao mesmo tempo, também um re- 
presentante dessa cultura, que se apropria dos seus materiais - não de todo conscientemente - e se diferencia. Esse sofrimento é também natureza, que a cultura esclarecida gostaria de extirpar, mas não é só natureza, no reconhecimento do sofrimento, o sofrimento expresso e construído pode ser a porta para a reconciliação da cultura com a natureza, pois a diferenciação, na construção e na expressão do sofrimento não está pré-determinada, essa mímesis produtiva pode incluir, no futuro, a felicidade, o fim do próprio sofrimento.

Entre o "engole o choro" e "o(a) menino(a) sofre", emerge o verdadeiro eu, que nessa sociedade, só pode ser, ainda, o "eu sofro". O reconhecimento do sofrimento, na passagem de Proust e na sociedade atual como um todo, não elimina automaticamente o sofrimento. Sequer a pessoa de quem parte o reconhecimento - no caso de Proust, o pai - não sofre; sofre, e ainda engole o próprio choro. A autonomia, nessa sociedade, só pode ainda ser a autonomia de reconhecer o sofrimento, não de eliminá-lo; qualquer pretensão de autonomia no particular além dessa, no momento, em face da não-autonomia do todo, é ideologia e consolação.

Por outro lado, a consciência mais progressista hoje é a consciência de que a diferenciação, no particular, possível a partir do reconhecimento desse sofrimento, pode eliminar o sofrimento um dia, no todo. Uma professora querida, Maria Helena Souza Patto, certa vez começou uma aula com a seguinte frase, da primeira linha de Ana Karênina: "Todas as famílias felizes se parecem entre si; as infelizes o são cada uma a sua maneira”. Essa frase já contém o conhecimento - consciente ou não, mas que podemos assumir a partir de sua crítica - de que a felicidade hoje só pode ser conseguida com a renúncia à autonomia, é sofrimento adaptado, enquanto a consciência do sofrimento é resistência à adaptação, e já é, “apesar dos pesares", alguma autonomia.

Essa consciência, como vimos, não é nem absoluta, nem tão consciente assim; sempre permanece algo de enigmático. E a arte, enquanto objetificação da consciência, é um enigma que propõe sua "solução insolúvel”. Por isso seu uso pedagógico, para uma pedagogia tecnicista e adaptacionista, é um perigo que precisa ser escondido por sucessivas camadas idênticas do lixo produzido pela Indústria Cultural - em termos absolutos, realmente a realidade predominante - ou apaziguada em seu caráter explosivo pelo seu tratamento dado ao que há de moderno 
e radical, em qualquer época, como se fosse apenas mais um produto dessa Indústria, cabível em critérios como prazer, diversão, sucesso e utilidade.

Se nos perguntassem, a partir desse estudo, se é possível uma formação sem a arte, responderíamos: não; ao menos não em nossa sociedade, da forma em que ela se desenvolveu até hoje. A própria formulação dessa pergunta já demonstraria uma desconsideração pela história do homem e uma tentativa de dominação da natureza humana, a começar pela negação do próprio caráter cultural dessa natureza. Em nossa sociedade, a arte autônoma foi historicamente o lugar da cultura em que o homem podia constituir uma relação com o mundo que não fosse nem pela magia, nem pela técnica isolada; nem retorno à natureza, nem avanço à barbárie. Uma sociedade em que a arte não tivesse mais esse lugar não seria mais a nossa. Mesmo no atual estágio de degeneração da arte, a degeneração da formação a acompanha e a produz (ao mesmo tempo). A Indústria Cultural e a semiformação, em sua união, dão testemunho, pelo avesso, de que a verdadeira formação e a verdadeira arte são possíveis, e caminham juntas.

Da mesma forma, caso nos perguntassem se a arte forma, responderíamos: sim, a verdadeira experiência com a obra de arte forma, quer se queira isso dela quer não, porque o encontro com a obra, e seu caráter de aparência, esse brilho que não se deixa reduzir a uma função, esse enigma, é também um encontro com a positividade do próprio sofrimento, com aquilo que nos determina até hoje, e é também um encontro com a negatividade de todas as possibilidades abertas pela memória e consciência atual desse sofrimento; possibilidade, inclusive, da felicidade. Essa é, para nós, a emancipação possível, por enquanto. 


\section{Bibliografia}

ADORNO, T. W. Introduction to the sociology of music. New York: The Seabury Press, 1976.

. Minima moralia: reflexões a partir da vida danificada. Trad. de Luiz Eduardo Bicca. São Paulo: Editora Ática, 1992.

. Analytical Study of the NBC "Music Appreciation Hour". In: The Musical Quarterly, Vol. 78, nº 2, pp. 325-377, 1994a.

. Sobre Música Popular. In: CoHn, G. (org.). Theodor W. Adorno. Coleção Grandes Cientistas Sociais. São Paulo: Editora Ática, 1994 b.

Palavras e sinais: modelos críticos 2. Petrópolis: Editora Vozes, 1995 a.

. Notas marginais sobre teoria e práxis. In: los críticos 2. Petrópolis: Editora Vozes, 1995b.

Palavras e sinais: mode-

Teoria da semicultura. In: Educação e Sociedade, no 56, ano XVII, pp. 388 411, 1996.

. Aesthetic theory. Minneapolis: University of Minnesota Press, 1997.

. Crítica cultural e Sociedade. In: dade. São Paulo: Ática, 1998.

Prismas: crítica cultural e socie-

. A arte é alegre? In: PUCCI, B. et al. Teoria crítica, estética e educação. Campinas/Piracicaba: Autores Associados/Unimep, 2001a.

Teses sobre religião e arte hoje. In: PUCCI, B. et al. Teoria crítica, estética e educação. Campinas/Piracicaba: Autores Associados/Unimep, 2001 b.

. Educação e emancipação. São Paulo: Editora Paz e Terra, 2003a.

. Educação após Auschwitz. In: lo: Editora Paz e Terra, 2003b.

. Educação e emancipação. São Pau-

Educação e emancipação. In: Editora Paz e Terra, 2003c.

. Educação e emancipação. São Paulo:

Educação - para quê? In: Editora Paz e Terra, 2003d. . Educação e emancipação. São Paulo:

O ensaio como forma. In: . Notas de literatura I. São Paulo: Editora $34,2003 \mathrm{e}$.

. Experiência e Criação Artística. Lisboa: Edições 70, $2003 \mathrm{f}$.

A filosofia e os professores. In: lo: Editora Paz e Terra, 2003g. . Educação e emancipação. São Pau-

. A filosofia muda o mundo ao manter-se como teoria. In: Lua Nova, $n^{\circ} 60$, pp. 131-139, 2003h.

. Palestra sobre lírica e sociedade. In: lo: Editora 34, 2003i. Notas de literatura I. São Pau- 
. Tabus acerca do magistério. In:

Paulo: Editora Paz e Terra, 2003j.

. Educação e emancipação. São

. Teoria estética. Lisboa: Edições 70, 2006.

. A idéia de história natural. Disponível em http://poars1982.wordpress.

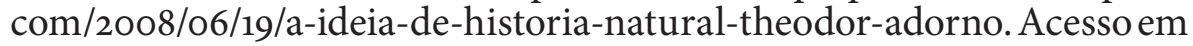
24.08.2010. Publicado em 2008a.

. Lectures on negative dialectics: fragments of a lecture course 1965/1966. Malden: Polity Press, 2008b.

. Dialética negativa. Rio de Janeiro: Zahar, 2009.

ADORNO, T.W.; FRENKEL-BRUNSWIK, E.; LEVINSON, D.J.; SANFORD, R.N. La personalidad autoritaria. Buenos Aires: Editorial Proyección, 1965.

ADORNO, T. W.; HOR KHEIMER, M. Cultura e civilização. In: Temas básicos da sociologia. São Paulo: Cultrix, 1973a.

. Indivíduo. In: $1973 b$. . Temas básicos da sociologia. São Paulo: Cultrix,

. Dialética do esclarecimento. Rio de Janeiro: Jorge Zahar Editor, 1985.

ALMeida, J. Crítica dialética em Theodor Adorno: música e verdade nos anos vinte. Cotia: Ateliê Editorial, 2007

AlmeidA, J. Introdução. In: ALMeidA, J.; BADER, w. (org.). Pensamento alemão no século xx. São Paulo: Cosac Naify, 2009.

ARISTÓteles. Arte poética. São Paulo: Difel, 1964.

AUerbach, E. Mimesis. São Paulo: Perspectiva, 2009.

BARBOSA, R. Introdução. In: SCHILlER, J.F. Cultura estética e liberdade. São Paulo: Hedra, 2009.

BATista, s.s.s. Teoria Crítica e Educação: a contribuição do pensamento de T.W. Adorno. Dissertação de Mestrado apresentada ao Instituto de Psicologia da Universidade de São Paulo. São Paulo, 88p, 1997.

. Elementos para uma reflexão sobre arte e educação a partir da Teoria Crítica. Tese de Doutorado apresentada ao Instituto de Psicologia da Universidade de São Paulo. São Paulo, 249p, 2002.

BENJAMIN, w. A capacidade mimética. In: AXelos, K. et al. Humanismo e comunicação de massa. Rio de Janeiro: Tempo Brasileiro, 1970.

. Problemas da sociologia da linguagem. In: guagem e política. Lisboa: Relógio D’Água, 1992a.

. Sobre a linguagem geral e sobre a linguagem humana. In: Sobre arte, técnica, linguagem e política. Lisboa: Relógio D’Água, 1992b.

. Teses sobre a filosofia da história In: gem e política. Lisboa: Relógio D’Água, 1992c. Sobre arte, técnica, lingua- 
. A obra de arte na era de sua reprodutibilidade técnica. In: Obras escolhidas I. São Paulo: Brasiliense, 1996a.

. Sobre o conceito de História.In: Obras escolhidas I. São Paulo: Brasiliense, 1996b.

Sobre alguns temas em Baudelaire. In: . Obras Escolhidas III. São Paulo: Brasiliense, 2000.

. Origem do drama trágico alemão. Lisboa: Assírio \& Alvim, 2004.

. As afinidades eletivas de Goethe. In: Ensaios reunidos: escritos sobre Goethe. São Paulo: Editora 34, 2009a.

. Goethe. In: Editora $3 \overline{4,2009 b \text {. }}$.

BOLLE, W. A idéia de formação na modernidade. In: GHIRALDELLI JR., P. (org.). Infância, escola e modernidade. São Paulo/Curitiba: Cortez/Editora da Universidade Federal do Paraná, 1997.

Bronner, S.E. Da Teoria Crítica e seus teóricos. São Paulo: Papirus Editora, 1994.

CARONE, I. Adorno e a educação musical pelo rádio. In: Educação e Sociedade, vol. $24, n^{\circ} 83$, pp. 477-494, 2003.

DuARTE, R.A.P. Mímesis e racionalidade. Coleção Filosofia. São Paulo: Edições Loyola, 1993.

EAgleton, T. A ideologia da estética. Rio de Janeiro: Jorge Zahar Editor, 1993.

FOUCAULT, M. O que são as luzes? In: Arqueologia das ciências e história dos sistemas de pensamento. Rio de Janeiro: Forense Universitária, 2000.

GAGNebin, J. Baudelaire, Benjamin e o moderno. In: . Sete aulas sobre linguagem, memória e história. Rio de Janeiro: Imago, 2005a.

Sobre o conceito de mímesis no pensamento de Adorno e Benjamin. In: . Sete aulas sobre linguagem, memória e história. Rio de Janeiro: Imago, 2005b.

. Infância e pensamento. In: e história. Rio de Janeiro: Imago, 2005c.

Sete aulas sobre linguagem, memória

“Após Auschwitz". In: . Lembrar escrever esquecer. São Paulo, Editora 34, 2009a.

Sobre as relações entre ética e estética no pensamento de Adorno. In: Lembrar escrever esquecer. São Paulo: Editora 34, 2009b.

. Walter Benjamin: estética e experiência histórica. In: ALMEIDA, J.; BADER, w. (org.). Pensamento alemão no século xx. São Paulo: Cosac Naify, 2009C.

Gassner, J. Mestres do teatro I. São Paulo: Perspectiva, 1991.

Goethe, J. w. Os anos de aprendizado de Wilhelm Meister. São Paulo: Editora 34, 2009. 
GOETHE, J. W.; SCHILleR, J. F. Correspondência. São Paulo: Hedra, 2010.

habermas, J. O discurso filosófico da modernida. São Paulo: Martins Fontes, 2002.

HULlOT-Kentor, R. Back to Adorno. In. Things beyond resemblance: collected essays on Thedor W. Adorno. New York: Columbia University Press, 2006a.

. Second salvage: prolegomenon to a reconstruction of Current of music. In. $ـ$ Things beyond resemblance: collected essays on Thedor W. Adorno. New York: Columbia University Press, 2006b.

. Em que sentido exatamente a indústria cultural não mais existe. In: DURÃo, F. A. et al. A indústria cultural hoje. São Paulo: Boitempo, 2008.

JAY, M. Teoria estetica y la crítica de la cultura de masas. In: dialéctica. Madri: Taurus Editora, 1974. La imaginacion

. As idéias de Adorno. São Paulo: Cultrix/Edusp, 1988.

Jimenez, M. Theodor Adorno: arte, ideologia y teoria del arte. Buenos Aires: Amorrotu Editores, 1977.

KANT, I. Crítica da faculdade do juízo. Rio de Janeiro: Forense Universitária, 2005.

. Resposta à pergunta: que é "Esclarecimento"? In: Petrópolis: Vozes, 2009. Textos seletos.

LeIbniz, G.w. Leibniz. Coleção Os Pensadores. São Paulo: Nova Cultural, 2004.

LUKÁcs, G. A teoria do romance. São Paulo: Editora 34, 2000.

. Posfácio. In: Goethe, J. w. Os anos de aprendizado de Wilhelm Meister. São Paulo: Editora 34, 2009.

MAAR, W. L. A guisa de introdução: Adorno e a experiência formativa. In: ADORNO, T.w. Educação e emancipação. São Paulo: Editora Paz e Terra, 2003.

MARCUSE, H. A ideologia da sociedade industrial. Rio de Janeiro: Zahar Editores, 1967.

Sobre o caráter afirmativo da cultura. In: Cultura e sociedade, vol. 1. São Paulo: Paz e Terra, 1997.

MARX, K. O Capital. Trad. de Régis Barbosa e Flávio Kothe. Coleção Os Economistas. São Paulo: Abril Cultural, 1982.

MAZZARI, M.V. Apresentação. In: GOETHE, J. W. Os anos de aprendizado de Wilhelm Meister. São Paulo: Editora 34, 2009.

PROUST, M. Em busca do tempo perdido, vol. 1 - No caminho de Swann. São Paulo: Globo, 2006.

ROSENFELD, A. Introdução. In: SCHILlER, J.F. Cartas sobre a educação estética da humanidade. São Paulo: EPU, 2009.

SAfatle, v. A paixão do negativo: Lacan e a dialética. São Paulo: Editora Unesp, 2006. 
SAFATLE, V. Theodor Adorno: a unidade de uma experiência filosófica plural. In: Almeida, J.; BAder, w. (org.). Pensamento alemão no século XX. São Paulo: Cosac Naify, 2009.

SCHILlER, J.F. Cartas sobre a educação estética da humanidade. São Paulo: EPU, 2009a.

SCHILlER, J.F. Cultura estética e liberdade. São Paulo: Hedra, 2009 b.

Seligmann-silva, M. A atualidade de Walter Benjamin e de Theodor W. Adorno. Rio de Janeiro: Civilização Brasileira, 2009.

SILVA, E.S.N. Mímesis e forma: a crítica de Habermas a Adorno (e uma resposta). In: DUARTE, R. et al. Theoria Aesthetica. Porto Alegre: Escritos Editora, 2005 .

SUAREZ, R. Nota sobre o conceito de Bildung (formação cultural). Kriterion: revista de filosofia, vol. 46, nº 112. Belo Horizonte: 2005.

Sussekind, P. A Grécia de Winckelmann. Kriterion: revista de filosofia, vol. 49, no 117, pp. 67-77. Belo Horizonte: 2008.

TIBURI, M. Crítica da razão e mímesis no pensamento de Theodor W. Adorno. Coleção Filosofia, nº 26. Porto Alegre: EDIPUCRS, 1995.

Wiggershaus, R. A Escola de Frankfurt. Rio de Janeiro: Difel, 2002. 